\title{
A REVISION OF AFRICAN LAEMOPHLOEINAE (COLEOPTERA : CUCUJIDAE)
}

\section{P. LEFKOVITCH}

Pest Infestation Laboratory, Slough

Pp. I65-245; 82 Text-figures

BULLETIN OF

THE BRITISH MUSEUM (NATURAL HISTORY) ENTOMOLOGY Vol. I2 No. 4 LONDON : 1962 
THE BULLETIN OF THE BRITISH MUSEUM (NATURAL HISTORY), instituted in I949, is issued in five series corresponding to the Departments of the Museum, and an Historical Series.

Parts will appear at irregular intervals as they become ready. Volumes will contain about three or four hundred pages, and will not necessarily be completed within one calendar year.

This paper is Vol. I2, No. 4 of the Entomological series. The abbreviated titles of periodicals cited follow those of the World List of Scientific Periodicals.

(c) Trustees of the British Museum 1962

PRINTED BY ORDER OF THE TRUSTEES OF THE BRITISH MUSEUM 


\title{
A REVISION OF AFRICAN LAEMOPHLOEINAE (COLEOPTERA : CUCUJIDAE)
}

\author{
By L. P. LEFKOVITCH
}

CONTENTS

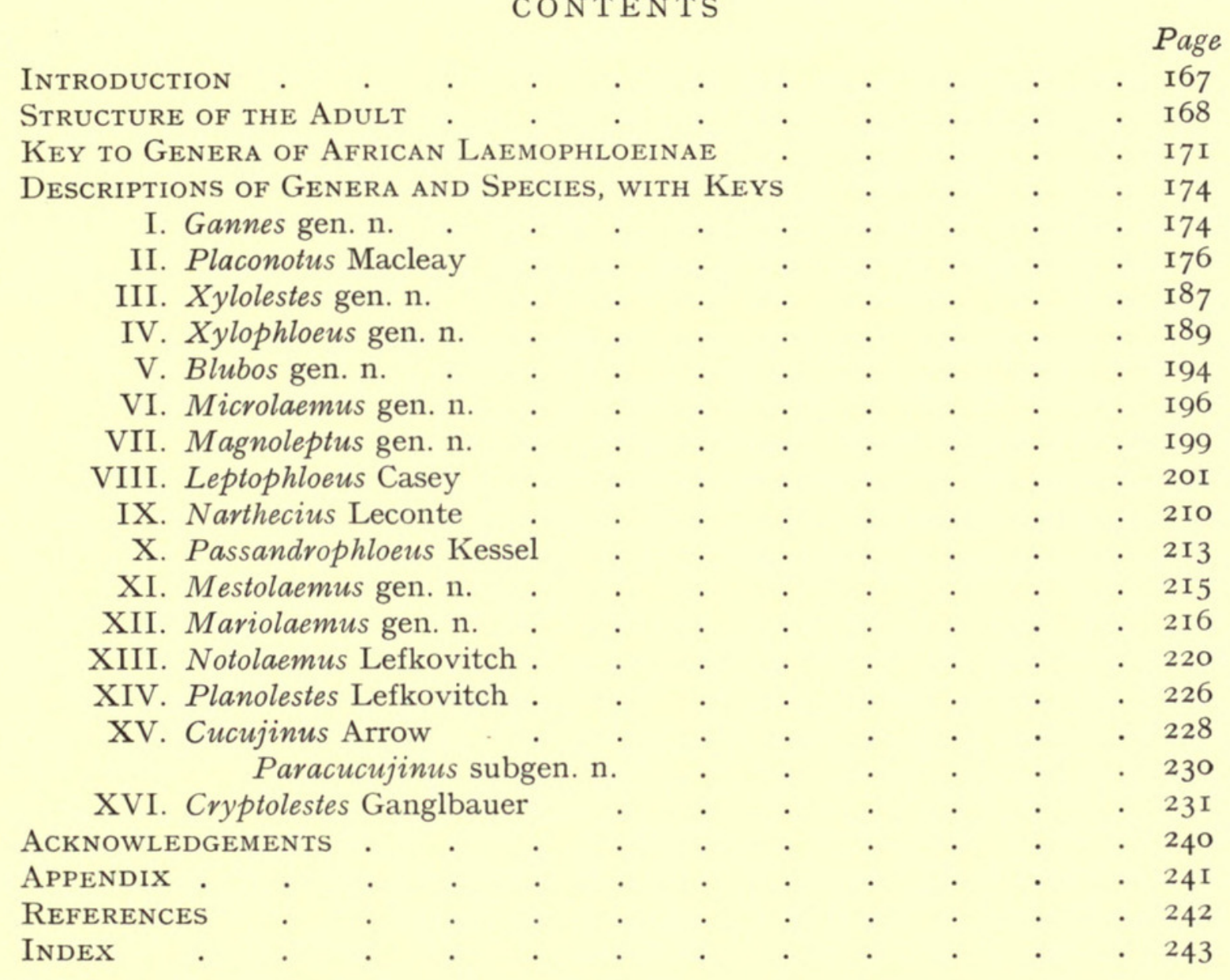

SYNOPSIS

Keys to, and descriptions of, sixteen genera, one subgenus and eighty-six species of Laemophloeinae from the Ethiopian region (including Madagascar, Madeira, the Canaries and the Salvages) and some North African species which are primarily Palaearctic are provided. Eight new genera, one new subgenus and thirty-nine new species are described; two new generic and eleven new specific synonymies are made.

\section{N T RODUCTI ON}

IN a previous paper (Lefkovitch, I959b), it was pointed out that Laemophloeus was a heterogeneous group. Based upon a study of species occurring in Europe, the genus was divided into more natural assemblages which were considered to merit generic status. Since a number of species of the Laemophloeinae are of economic importance, it was considered justifiable to extend the study of the group to those species not occurring in Europe. This paper is the first of such studies. 
The species considered here are from the Ethiopian region including Madagascar (some species from Madagascar belong to a fauna whose affinities are with the Oriental or Pacific regions) and those apparently native to Madeira, the Canaries and the Salvages; those North African species which are primarily European and represented in Mediterranean Africa but are here excluded are Lathropus sepicola (Müller), Laemophloeus nigricollis Lucas, L. monilis (Fabricius), L. muticus (Fabricius), Notolaemus castaneus (Erichson), N. unifasciatus (Latreille), Cryptolestes duplicatus (Waltl), C. fractipennis (Motschulsky), C. corticinus (Erichson), Placonotus testaceus (Fabricius), Leptophloeus alternans (Erichson), L. juniperi (Grouvelle), L. hypobori (Perris) and L. clematidis (Erichson); reference should be made to Lefkovitch $(\mathrm{I} 959 b)$ for a discussion of these.

There is one African species Laemophloeus notabilis Grouvelle, I904: I83, whose type specimens I have been unable to see and whose description is inadequate for its generic position to be established. It should be regarded as a species incertae sedis for the present. So far as I know, all other previously described species have been included.

The most interesting point that has arisen from the study of the African and European species of the subfamily (Lefkovitch, I959b) is the difficulty in finding adult characters which would enable a tribal grouping of the genera. Quite clearly, Cucujinus Arrow, by its extreme flattening, the grooved prothoracic sublateral lines, the large contribution made by the metepisternum to the mesocoxal cavity and the curved suture between that sclerite and the metasternum, is distinct from the other genera. This degree of difference is such that the lack of apparent comparable differences between the other genera suggests that the appropriate phylogenetic characters are yet to be discovered. The recognition of these characters may be easier after a study of the Laemophloeinae in the remainder of the world. No tribal grouping of the genera will therefore be attempted at this stage.

Data relating to specimens consisting of "Miss. H. de Saeger" followed by a number are given in the appendix ; further details are given by de Saeger (I956). The specimens were collected in Garamba in the Congo.

\section{GENERAL STRUCTURE OF ADULT LAEMOPHLOEINAE}

HEAD. The head is perhaps the most obviously variable part of the body. The lateral lines, which when present (they are absent in Lathropus) have much the same structure as those of the pronotum, may often be joined anteriorly by a transverse line. In some genera, this transverse line is in fact a groove, which together with the median impressed line suggests the primitive Y-shaped epicranial sutures, e.g. Text-fig. 5. These sutures are not homologous with the ecdysial lines of immature stages of Coleoptera and the transverse suture is probably between the ante- and postclypeus and not between the frons and the clypeus. In some other genera the transverse line is raised and is obviously no more than a transverse continuation of the lateral lines. In some of these genera, examination by transmitted light reveals a transverse suture in the head which does not coincide with the transverse line. In the broadest terms, the shape of the head varies from 
truncated triangular to rectangular and can even be rostrate as in Rhinolaemus, Rhinophloeus and Rhinomalus. In general the gular sutures are visible in all the genera and are never confluent even in those genera (e.g. Magnoleptus gen. n.) which recall the Passandridae in their general appearance. The anterior angles of the genae are variable in the degree of development; in most genera they present no unusual features but in those genera in which males have a lateral expansion externally upon the mandibles, the genae are often enlarged proportionally. In males of Passandrophloeus the degree of development is such that mandibular development is quite clearly linked with that of the genae, which appear to prevent the mandibles from crossing too far in the median line (Text-fig. 39). Antennae vary to some extent in the subfamily ; the scape, pedicel and three-segmented club may be considerably more robust than the intermediate segments (e.g. Lathropus); the degree of size differentiation is almost imperceptible in some genera; the antennal segments may even be quite elongate and a club completely indistinguishable. Sexual dimorphism may be apparent in the structure of the antenna. In males of many species in many genera, the antennal segments are elongate and there is no apparent club (e.g. Text-fig. 54), whereas those of females are shorter and a club is often quite distinct (e.g. Text-fig. 64). In addition, the male antennae may be as long as, or longer than the rest of the body whereas those of females of the same species are often equal to no more than half the body length. In some species the scape of the male is developed into an unusual form (Lefkovitch, I958b); two species with such developments occur in the African region.

MouTHPARTs. Laemophloeinae may be distinguished from other Cucujidae in that the lacinia is completely devoid of setae. As noted above, the mandibles may be produced laterally, resembling the condition in males of some species of Uleiota.

In this paper, "front of the head" refers to the dorsal margin between the antennal insertions, "epistome" to that part of the margin above the mouthparts.

Pronotum. In general, the pronotum is broader than long, although in Leptophloeus and Narthecius the reverse may hold. Normally the anterior angles are distinct but are less prominent than the posterior angles except in Gannes and some Placonotus. Each lateral line (stria of earlier authors) may consist of a simple raised ridge (e.g. Text-fig. 20) or it may be a double structure consisting of a raised ridge and an internal groove, the whole appearing as a single structure (e.g. Text-fig. 24). In some genera the groove may deepen behind the midpoint and form a deep fovea (e.g. Text-fig. 5). A line of punctures may be situated adjacent to the ridge externally, their outer margins sometimes running together to form what appears to be a second lateral line (e.g. Text-fig. 40). When such a condition holds, it is usually easy to decide which of the two lateral lines is the primary since the outer margin of the raised part of the primary line is continuous with the line adjacent to the anterior and posterior margins of the sclerite. In Cucujinus the lateral line is simply an elongate groove without any distinct edges, disappearing anteriorly and posteriorly before reaching the edge of the sclerite (Text-fig. 55).

Elytra. Punctured striae are typical and are probably always present. However, superimposed upon this puncturation there is in many genera a system 
of longitudinal raised areas. The position of these raised areas is quite constant. They occur in the first, third, fifth and seventh intervals of each elytron, but there is some variation between genera, and between the species in some genera, in the degree of elevation and in the lateral width. The regions enclosed by these raised areas, which are continuous both apically and basally, are called a cell for the purposes of this paper. The longitudinal raised region between the cells is here called a secondary interval. The secondary intervals may be quite narrow as in Microlaemus (Text-fig. 24) in which case the primary strial interval may then be considered to be carinate or just elevated ; or they may be broad as in Magnoleptus, where an accurate brief description of the primary interval may be difficult to give (Text-fig. 27). It is quite clear that each cell contains two rows of punctured striae and that any rows of punctures situated on a secondary interval do not represent striae (Text-fig. I). Secondary rows of punctures may be present in the cells in addition to the striae, e.g. in Cryptolestes capensis which has one additional row and in C. ferrugineus which has two. A brief examination will often suffice to distinguish which rows of punctures are striae and which are secondary.

VENTRAL SIDE OF THE THORAX. The pro-episternal region is quite distinct and the suture between this sclerite and the prosternum often reaches the lateral margin of the prothorax. The pro-epimeron is often exposed and may close the anterior coxal cavity in conjunction with the intercoxal process of the prosternum (Text-fig. 38). The amount of closure of the anterior cavities is variable ; the cavities may be open posteriorly (Text-fig. I9), they may be closed by a meeting of the prosternum and epimeron either as points (Text-fig. I3) or in a broad front (Text-fig. 38). The prosternal process may be either very broad (Text-fig. 56) or very narrow (Text-fig. $2 \mathrm{I}$ ). It may be straight posteriorly, convex or concave. These features may be of

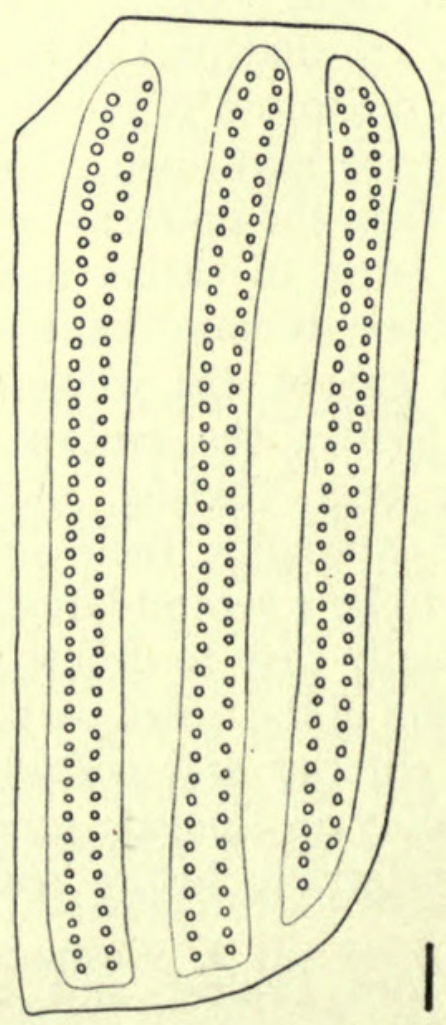

FIG. I. Diagrammatic dorsal view of right elytron of typical Laemophloeinae. 
value in a tribal classification, since they must be of importance in the kind of movement that the animal is able to make and thus of significance in the evolution of the group. There is some variation in the construction of the ventral side of the mesothorax in different genera. In most genera both the mesepisternum and the mesepimeron form part of the mesocoxal cavity, or if the mesepimeron does not, then it only just fails to do so. In many genera the metepisternum either does not contribute to the mesocoxal cavity (Text-fig. I5) or only just does so, but in Cucujinus the contribution of this sclerite is such that it forms an important part of the posterolateral margin of the cavity (Text-fig. 56).

The metasternum presents no special features except in the degree of definition of the median suture, and in the shape of that region in contact with the intercoxal process of the first visible abdominal sternite.

VENTRAL SIDE OF THE ABDOMEN. The intercoxal process of the first visible abdominal sternite has been considered by Lefkovitch (I959b); nothing further has been revealed by the African species of the subfamily. There is considerable variation in the overall shape of the five sternites which are visible, but it seems likely that this variation represents generic and not tribal differences. In general, either the first four visible sternites are as broad as each other or they become progressively narrower, the fifth sternite always being the narrowest. The first sternite is longest although the fifth sternite may be nearly as long as the first in some genera.

LEGS. The legs show a certain amount of variation although much of this is often specific in character. The trochantero-femoral junctions are usually of the normal type, but occasionally an approach to both the heteromeroid and the elongate type may be seen. The femora are often dilated, and, in very flattened species, the dilation may be considerable in one plane. The tibiae are usually slightly sinuate and bear two spines apically. In the peculiar Laemophloeus mirificus Grouvelle, these two spines are produced into setae which are equal in length to the combined lengths of the tarsal segments. The tarsi are usually five-segmented but may be four-segmented in the hind legs only, as in the males of many species. The basal four segments together are usually slightly longer than the terminal segment, but may be much shorter as in Lathropus Erichson, where the basal segments are shortened, or as in Laemophloeus gestroi Grouvelle where the terminal segments are considerably elongate in comparison with the usual condition. The terminal segment is never short. There is at most the very smallest indication of lobing of the segments ventrally.

(The generic attribution of mirificus and gestroi has not yet been established.)

\section{Key to Genera}

I. Frontoclypeal suture situated at the base of a transverse groove .

2. Intercoxal process of the first abdominal sternite pointed anteriorly; anterior angles of the pronotum never produced into an acute tooth

LAEMOPHLOEUS Dejean ${ }^{1}$

1 This genus is included in the key since although it is not represented in the Ethiopean region proper, it is represented in Mediterranean Africa: supra p. I68. 
- Intercoxal process of the first abdominal sternite straight or slightly rounded anteriorly ; anterior angles of the pronotum often produced into an acute tooth

3. Elytra always covering the whole abdomen; last visible abdominal sternite in the mid-line at most only slightly longer than the preceding sternite; pronotum $\mathrm{I} \cdot 3$ times as broad as long; right mandible of male produced laterally and dorsally

- Elytra leaving at least the tip of the abdomen exposed (Text-fig. 3), often the last segment is completely exposed dorsally ; last visible abdominal sternite usually distinctly longer than the preceding sternite, often twice as long; pronotum usually quadrate or very slightly transverse ; mandibles of the male without any lateral production

II. PLACONOTUS Macleay (p. I76)

4. Head strongly produced anteriorly to the antennal insertions forming a distinct rostrum, this region being broad and flattened; pronotal lines strongly carinate ; anterior coxal cavities widely open posteriorly; coxae very close together on each segment, separated by a distance equal to less than the width of a coxa ; intercoxal process of the first visible abdominal sternite pointed anteriorly; antennae very short, hardly reaching the mid-point of the pronotum

\section{Laemophloeus raffrayi Grouvelle ${ }^{1}$}

- Head only normally developed anteriorly to the antennal insertions or not produced at all ; pronotal lines only weakly carinate ; anterior coxal cavities either broadly or narrowly open, or closed posteriorly ; coxae separated by a distance equal to or greater than the width of a coxa ; intercoxal process of the first visible abdominal sternite never pointed anteriorly; antennae usually reaching at least the mid-point of the pronotum .

5. Lateral lines on the head joined transversely just behind and very close to but distinct from the epistome by an almost straight but sometimes irregular line, this line possibly representing the frontoclypeal suture

- Lateral lines of head, if joined by a line, the line is not straight but clearly curved (or the line is the line of the epistome)

6. Labrum truncate or shallowly emarginate anteriorly ; antennae usually inserted at the front corners of the head ; eyes usually occupying slightly more than one-third of the lateral margin of the head measured from the front angles to the base

III. XYLOLESTES gen. n. (p. I87)

- Labrum evenly rounded anteriorly; antennae usually inserted laterally on the head, behind the front corners ; eyes usually occupying about one-quarter of the lateral margin of the head

IV. XYLOPHLOEUS gen. n. (p.

7. Lateral lines of pronotum never reaching its base (Text-fig. 55) ; head expanding laterally from base to just behind eyes, at widest usually broader than the pronotum ; elytra leaving at least the last and often the preceding segments exposed

XV. CUCUJINUS Arrow (p. 228)

- Lateral lines of the pronotum always reaching its base; head parallel-sided from base to eyes, at most as broad as the pronotum; elytra never leaving more than the tip of the pygidium exposed

8. Prothorax with suture between pronotum and pro-episternum visible dorsally; about $4 \mathrm{~mm}$. in length and Carabid-like in general appearance ; elytra with very distinct punctate striae (Text-fig. 20) . . . . V. BLUBOS gen. n. (p. I94)

- Prothorax with suture between pronotum and pro-episternum not visible dorsally or if so, beetles cylindrical, resembling some Colydiidae and about $2 \mathrm{~mm}$. in length ; elytra with less distinct punctate striae . . . . . . .

9. Epistome either rounded, truncate, or with a single medial spine anteriorly or with two teeth (Text-figs. 28-30) or, if with one emargination, either the mesepimera

1 This species does not belong to the Cucujidae and a detailed study has failed to show its proper family position. It is included here since it was originally described as a Laemophloeus and could possibly be misidentified as a Laemophloeine (see Lefkovitch, I962). 
contribute to the mesocoxal cavities or the body is never longer than $3 \mathrm{~mm}$. and the clypeus is rarely produced into horns in males . . . . . .

- Epistome with three or five emarginations or, if with one emargination, either the mesepimera do not contribute to the mesocoxal cavities or the clypeus is always produced into horns in the males (Text-fig. 54) and the body is usually $3 \mathrm{~mm}$. or more in length . . . . . . . . . . . .

rontoclypeal suture represented by a line strongly curved away from the mouthparts (Text-fig. 24) (in the smallest species, this line is not easily seen); a dark mark is present anteriorly on the lateral lines of the head at the junction between the lines and the frontoclypeal suture; first visible abdominal sternite 2.5 times as long as the second sternite in the mid-line; last visible abdominal sternite I. 5 times as long as the preceding sternite. VI. MICROLAEMUS gen. n. (p.

Frontoclypeal suture obsolete; no dark marks anteriorly on the lateral lines of the sternite in the mid-line; last visible abdominal sternite only rarely longer than the preceding sternite

II. Body almost cylindrical ; antennae less than half the body length in both sexes ; head and pronotum never with two carinae on each side

Body more flattened in section; antennae in female just less than half the body length or longer, in male often considerably longer than those of the female, often either as long as the body, or head and pronotum with two lines on each side, or these characters combined

12. Head longitudinally grooved on each side of a median epistomal horn

IX. NARTHECIUS Leconte (p. 210)

Head, if with a median epistomal horn, not longitudinally grooved on each side of it

I3. Larger beetles, $3.5-5.0 \mathrm{~mm}$. in length; male tarsal formula $5^{-5-4}$; body usually black or reddish black in colour . . . VII. MAGNOLEPTUS gen. n. (p. I99)

Smaller beetles, $\mathrm{I} \cdot 8-3.0 \mathrm{~mm}$. in length; tarsal formula in both sexes $5^{-5-5}$ (except in two species where it is 5-5-4); body usually brown in colour

VIII. LEPTOPHLOEUS Casey (p. 20I)

I4. Anterior coxal cavities with broad transverse extensions laterally (Text-fig. 38 ) ; head with two lateral lines on each side ; mandibles of male produced laterally and ventrally (Text-fig. 39) ; genal horns strongly developed, especially in males

X. PASSANDROPHLOEUS Kessel (p. 213)

- Anterior coxal cavities with narrow lateral transverse extensions; head rarely with two lateral lines on each side, usually with one; mandibles of the males of some species produced laterally but never ventrally; genal horns weakly developed

XVI. CRYPTOLESTES Ganglbauer (p. 23I)

I5. Front of head with a deep emargination just internal to the antennae (Text-fig. 43) ; five distinct emarginations exist between the insertions of the antennae

XI. MESTOLAEMUS gen. n. (p. 21 5)

- Front of head only shallowly emarginate just internal to the antennae; only one distinct emargination exists anteriorly on the head, that over the mouthparts ; very shallow more lateral emarginations may be present in larger species, but a deep emargination just medial to the antennae is never present . . .

I6. Intercoxal process of the first visible abdominal sternite evenly rounded anteriorly and without a straighter median section; frons produced anteriorly into two horns in males (in one species only the left horn is developed), these horns apparently being formed by the production of the external angles of the single epistomal emargination (Text-fig. 54); elytra carinate laterally, with secondary intervals well developed and continuing to the apices ; the secondary intervals may be as broad as the cells or narrower; beetles larger, $2 \cdot 3-3.5 \mathrm{~mm}$. in length (associated with Legume pods)

XIV, PLANOLESTES Lefkovitch (p. 226) 
- Intercoxal process of the first visible abdominal sternite rounded and with a straighter median section; frons not produced anteriorly into horns in either sex; elytra carinate or non-carinate laterally, if with raised secondary intervals then either the elytra become flat apically or the secondary intervals are always as broad as the cells; beetles usually smaller, $1 \cdot 5-2 \cdot 5 \mathrm{~mm}$. in length, if larger, then usually three emarginations are present anteriorly on the head . . . . .

I7. Posterior border of intercoxal process of prosternum concave for reception of mesosternum (Text-fig. 44); elytra not carinate laterally; beetles more convex in section and body rather short; elytra with only one raised interval, recurved near the humeral angle and with faint punctured striae ; scutellum semi-elliptical ; internal angle of metepisternum not contributing to the mesocoxal cavity, i.e. mesepimeron and metasternum in contact with each other

XII. MARIOLAEMUS gen. n. (p. 216)

- Posterior border of intercoxal process of prosternum evenly rounded (Text-fig. 53); elytra carinate laterally; beetles flattened in section and body longer; elytra with at least two raised intervals in addition to the punctured striae; scutellum triangular ; metepisternum contributing to the mesocoxal cavity, i.e. mesepimeron separated from metasternum by the anterior angle of the metepisternum

XIII. NOTOLAEMUS Lefkovitch (p. 220 )

DESCRIPTIONS OF GENERA AND SPECIES

\section{GANNES gen. n.}

Type species: Gannes immoderatus sp. n.

This genus is most closely related to Placonotus Macleay. It is distinguished from that genus by the characters given in the key (p. I72).

About 2 mm.; body flattened.

Head transverse ; eyes large, usually in contact with prothorax ; frontoclypeal suture distinct and situated at the base of a groove ; epistome truncate ; lateral line distinct and forming part of the dorsal margin of eye ; antennae about as long as body in male, shorter in female, in female there is a loose three-segmented club ; males with right mandibles produced laterally and dorsally.

Pronotum distinctly transverse, narrowing somewhat basally; anterior and posterior angles acute but hardly, if at all, produced; lateral line distinctly raised and with an accompanying depression, the line not punctured or foveolate along its length.

Scutellum semicircular; elytra carinate laterally, with the third cell complete (see p. I 70 ) and two other raised intervals.

Genae normal; gular sutures obsolete ; anterior coxal cavities closed posteriorly, circular and widely separated; intercoxal process of the prosternum slightly convex posteriorly; mesepimera not contributing to the mesocoxal cavities (Text-fig. 2 ); metasternum equal in length to the first two abdominal segments ; intercoxal process of first abdominal segment almost straight anteriorly; first visible abdominal sternite $I \cdot 5$ times as long as the second sternite, second, third and fourth sternites about equal to each other, fifth slightly longer; legs subequal; trochantero-femoral junctions of normal type ; tarsal formula 5-5-5 in female, 5-5-4 in male.

\section{KEY, TO SPECIES}

I. Head with punctures very slightly less in diameter than facets of eyes, separated by a polygonal micro-reticulation; discal setae about 2.5 times as long as diameter of a puncture; fifth antennal segment in males longer than the scape

2. ambiguus (Grouvelle) (p. I75) 
- Head with punctures much less than an eye facet in diameter (about 0.25 times), separated mainly by smooth cuticle but with small areas of irregular microreticulation; setae about 5 times as long as the diameter of a puncture; fifth antennal segment in males shorter than the scape . I. immoderatus sp. n. (p. I75)

\section{Gannes immoderatus sp. n.}

(Text-fig. 3)

I.9-2.3 mm.; body reddish yellow to blackish red in colour; elytra somewhat more yellow than the head and pronotum.

Head across eyes nearly as wide as pronotum at its widest; frontoclypeal suture evenly curved posteriorly; epistome rounded anteriorly; antennae as long as body in male, shorter in female; last three segments somewhat enlarged; head simply punctured, with a microreticulation, punctures separated by one to two diameters, each subtending a seta equal to five punctures in length ; pronotum with puncturation and setation as on the head ; elytra somewhat oval, broadest about a third of their length from the base and narrowing apically, evenly rounded to apico-sutural angle.

Congo, Uganda.

Holotype male "Yangambi I953. C. Donis z.2634 (= Synsepalum dulciferum Sch. and Th. : Sapotaceae) coll. R. Mayné. Com. et Bois Congo. R2439 " (Mus. R. Congo Belge) ; I paratype with same data as holotype except with z.2992 and R2440 ; I paratype with same data as holotype but with z.2672 (Mus. R. Congo Belge) ; 2 paratypes "Uganda Kampala 25.vii.I927 H. Hargreaves" (British Museum (Natural History)).

\section{Gannes ambiguus (Grouvelle) comb. n.}

Laemophloeus ambiguus Grouvelle, 1923.

This species differs from $G$. immoderatus sp. n. in that the setae on the head and pronotum are considerably shorter, the elytra are less narrowed apically, and the epistome is truncate whereas that of $G$. immoderatus is rounded anteriorly.

$\mathrm{I} \cdot 8-2 \cdot 3 \mathrm{~mm}$; body yellow to blackish red in colour.

Head across eyes as wide as or slightly narrower than pronotum ; frontoclypeal suture evenly curved posteriorly ; epistome truncate anteriorly ; antennae as long as the body in male and the last three segments not forming a club, in female antennae shorter than body and last three segments forming a loose club. Head evenly punctured, punctures separated by one diameter, micro-reticulated between the punctures; setae equal in length to 2.5 times diameter of one puncture. Pronotum with puncturation and setation as on head. Elytra less narrowed apically than in $G$. immoderatus sp. n., evenly rounded to apico-sutural angle.

EAst Africa, Congo.

Holotype female "Afrique orient. anglaise Forêt de Nairobi Alluaud et Jeannel Nov.-Dec. I9II-I700-St II " (Grouvelle coll.). Other specimens seen include : I “ Benito. Congo Franc. sp. nv." ; I " Ogoove Lambarene R. Ellenberger IgII ” I "Af. or. All. Amani/Eichelbaum/Laemophloeus testaceus F var A inéd " (Grouvelle collection, Muséum National d'Histoire Naturelle, Paris): I "Congo Belge M2 Kahuzi S7 III. 22-viii-I952. Dr. Schedl. S.708"; I "Recolté dans l'humus/ I.R.S.A.C.-Mus. Congo Kivu: Terr. Uvira, Mulenga I880-2010 m. (Vest. for. 
ombroph.) V-I95I. N. Leleup.” ; I "S/L'écorce de Canarium Schweinfurthi/Coll. Mus. Congo. Bas-Congo : Sanda. Courtois." ; I "Eala vii-I935. J. Ghesquière ”; I " A la lumière I.R.S.A.C.-Mus. Congo. Kivu : Terr. Masisi, $720 \mathrm{~m}$ Walikale (River Loa) xi-53. N. Leleup" ; I "Elisabethville -ii-I940 H. J. Brehdo" ; 2 " Kivu : Buranga 5-xii-I925 and 9-xii-I925. Dr. H. Schouteden" ; 3 "Yangambi, I952. C. Donis. z3032 (Synsepalum dulciferum Sch. and Th. : Sapotaceae) "; Miss. H. de Saeger, 3 (3649), I (35I9), 2 (3736), I (3738), I (260I), 2 (3379) (see Appendix) (Mus. R. Congo Belge) ; I " Uganda. Ruwenzori Range. Mahoma River 6,700 ft. I3-I6. viii.I952. D. S. Fletcher" ; I "R. E. Dent. Charia R.7800. July, I929" ; I "Ngong Forest in Boletus. Nairobi B.E. Africa 4.x.I920. A. F. J. Gedye"”; 4 " Port St. John. Pondoland Sept. I923. R. E. Turner" ; 3 " Belgian Congo I8 m. sw of Elizabethville I3.xi.I927. Dr. H. S. Evans"; 2 "Nairobi .xi.I920"; (British Museum (Natural History)) ; 2 " Mt. Elgon O(st) A(frika) 2200 m. iv-25 leg Alinder" (Zoologische Sammlung des Bayerischen Staates, Munich).

\section{PLACONOTUS Macleay}

(Text-fig. 5)

Placonotus Macleay, 1871.

Silvanophloeus Sharp, I899.

Type species: Placonotus longicornis Macleay (by monotypy).
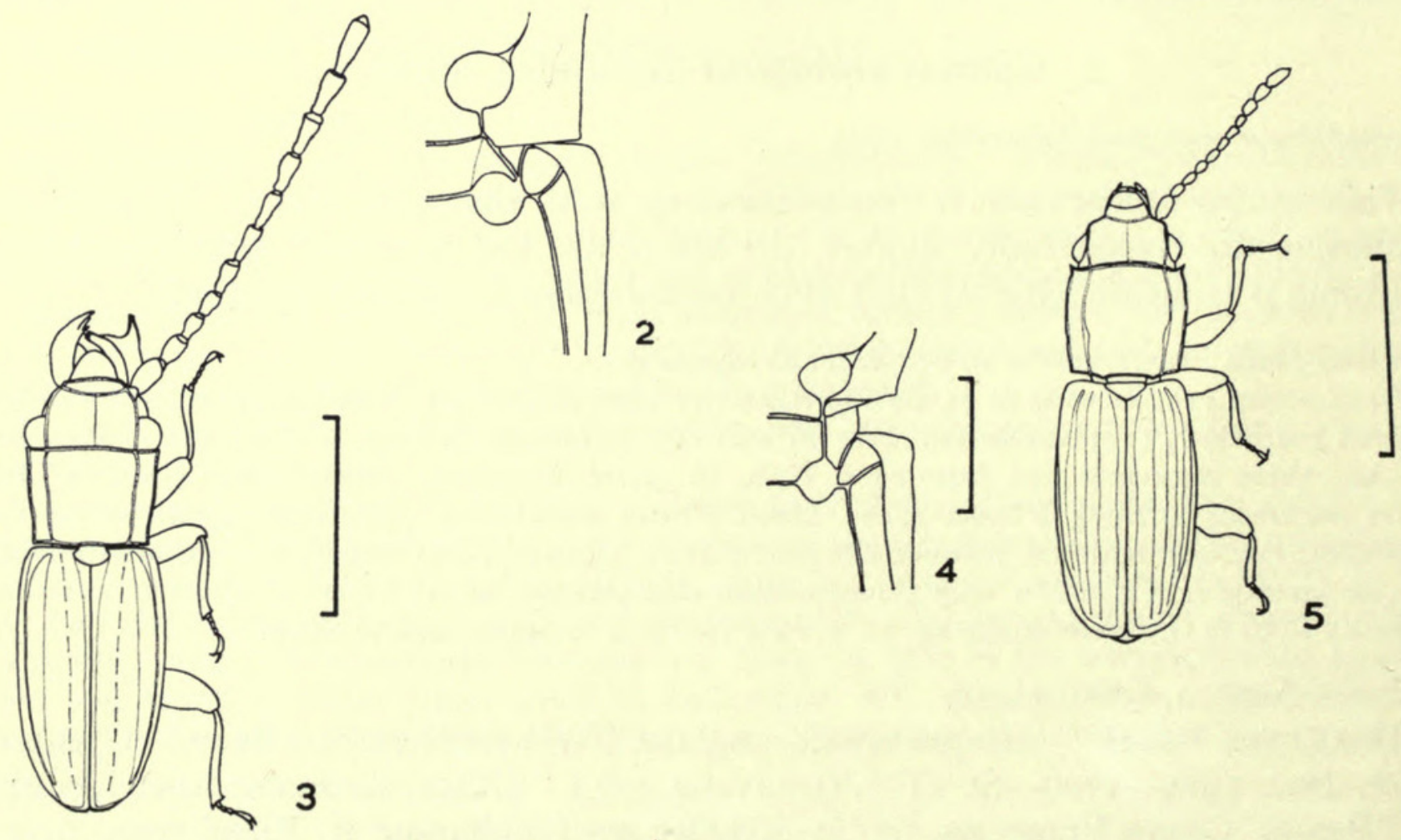

Figs. 2-5. (2) Front and middle coxal cavities of Gannes immoderatus ; (3) dorsal view of G. immoderatus; (4) front and middle coxal cavities of Placonotus testaceus (F.) ; (5) dorsal view of $P$. testaceus.

Scale lines: Figs. 2, $4=0.25 \mathrm{~mm}$. Figs. $3,5=1 \mathrm{~mm}$. 
A redescription of this genus is given by Lefkovitch (I959b). In addition to the characters indicated there, the following should be noted : Lateral line on head formed by raised ridge ; that of pronotum by a groove with outer margin slightly raised to form a weak ridge; genae normally developed ; gular sutures obsolete ; hind border of prosternal process convex posteriorly ; anterior coxal cavities circular ; metepisternum not contributing to mesocoxal cavity but both mesepisternum and mesepimeron do ; posterior border of mesosternum straight ; trochanterofemoral junctions of normal type.

The structure of the male genitalia presents points of interest in this genus. Two pairs of claspers are present which appear to be derived from the sclerites of the tenth abdominal segment. The tergite may be partially or completely divided along the median line to form two elongate rods; the sternite is always divided and articulated at its proximal end. Internally, the two sclerites may be tuberculate posteriorly. The protrusion of these claspers gives the impression that they are ovipositors; several specimens labelled by their collectors as females were found to be males with projecting claspers.

\section{Key to African Species}

I. Anterior angles of pronotum acute (Text-fig. 6)

- Anterior angles of pronotum rounded (Text-fig. 7)

2. Black or reddish black in colour, without a lighter mark on each elytron; epistome truncate anteriorly $\quad . \quad$. $\quad . \quad$. $\quad . \quad . \quad . \quad$ I. tastus sp. n. (p. I78)

- Head and pronotum brown or yellowish in colour, or if black, then each elytron with a lighter mark at basal third; epistome emarginate anteriorly .

3. Elytra unicolorous .

- Elytra with a lighter mark at basal third

4. Smaller species (about $\mathrm{I} \cdot 5^{-2} \mathrm{~mm}$.) ; pronotum distinctly transverse and head punctate; elytra $2 \cdot 5-3 \cdot 0$ times as long as their combined width . . . .

- Larger species (about I.8-2.3 mm.) ; pronotum about as broad as long or if transverse, then head impunctate ; elytra usually less than 2.5 times as long as their combined width

5. Epistome concave .

- Epistome convex.

6. Disc of head impunctate but strongly reticulate.

- Disc of head punctured .

7. Disc of head polygonally reticulate between punctures

- Disc of head smooth or with irregular groove-like markings between punctures .8

8. Elytra rounded together posteriorly (Text-fig. 8) . . 4. majus sp. n. (p. I79)

- Elytra separately rounded to apico-sutural angle, semitruncate (Text-fig. 9) . $\quad$. 9

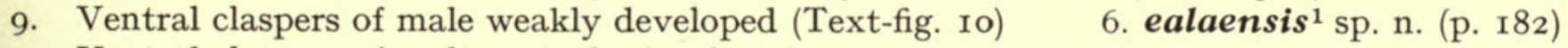

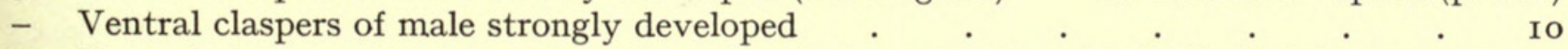

Io. Ventral claspers straight posteriorly ; dorsal claspers incompletely divided, in shape together equivalent to a normal tenth tergite (Text-fig. I I)

5. subtruncatus $^{1}$ sp. n. (p. I $8 \mathrm{I}$ )

Ventral claspers spatulate posteriorly; dorsal claspers completely divided except for a narrow strut anteriorly, posteriorly no broader than ventral claspers (Textfig. I2)

II. Head and pronotum reddish brown

. . . . . I2. exornatus (Grouvelle) (p. I86)

- Head and pronotum black . . . . . . I I. decoratus (Grouvelle) (p. I86)

I2. First visible abdominal sternite with femoral lines; pronotum convex between lateral lines ; anterior angles of pronotum not produced (Text-fig. 7)

9. politissimus (Wollaston) (p. 183 )

${ }^{1}$ Good characters for the separation of females have not been discovered. 
- First visible abdominal sternite without femoral lines; pronotum almost flat between the lateral lines; anterior angles of pronotum somewhat produced

Io. bolivari (Grouvelle) (p. 185)

\title{
I. Placonotus tastus sp. n.
}

\author{
(Text-fig. 6)
}

$2 \mathrm{~mm}$; ; body reddish black in colour, elytra less black than the head and pronotum ; shining but not brilliantly.

Head somewhat transverse, eyes large slightly in advance of base ; frontoclypeal suture with a raised ridge anterior to the shallow groove; epistome truncate anteriorly; antennae as long as body in male; disc evenly punctured, punctures separated by a distance equal to two to three diameters ; each puncture subtends a seta equal to about one diameter in length ; laterally on disc the intervals between punctures micro-reticulate, medially less so ; frons punctured just anterior to frontoclypeal suture but only reticulate just behind epistome.

Pronotum very slightly transverse and slightly narrowed basally, at its broadest slightly narrower than head; anterior angles acute and produced, posterior angles obtuse; disc with a small shallow depression on each side just anterior to the fovea included in lateral line ; disc with puncturation and setation as on disc of head; region between lateral line and lateral margin with more distinct micro-reticulation than on disc.

Elytra slightly broader across shoulders than pronotum at broadest; 2.5 times as long as their combined width; parallel-sided anteriorly but narrowing somewhat towards apices from about mid-point ; third cell developed basally, with part of first cell developed at about midpoint ; punctate striae present and complete until just before the apical region where they are obsolete; each elytron subtruncate apically, their combined median regions being straight; surface with micro-reticulation between punctures and lines.

Female unknown.

ETHIOPIA.

Holotype male "Abyssinia: Djem-Djem Forest. circa 8000 ft. 25-29.ix. I926. Dr. H. Scott.” (British Museum (Natural History)).

This species is most clearly distinguished from other Placonotus in its colour which is a very dark red or a slightly reddish black. In addition, the truncate epistome is unique amongst the African species of the genus having acute anterior angles to the pronotum.

\section{Placonotus dolce sp. $\mathrm{n}$.}

This species can be distinguished from other Placonotus in that it is quite small, the pronotum transverse, the ratio of length of elytra to their combined breadth is between 2.5 and 3 and has interesting double puncturing on the discs of both the head and the thorax.

$\mathrm{I} \cdot 5^{-2} \cdot \mathrm{o} \mathrm{mm}$. ; body brownish red in colour.

Head transverse ; eyes about half a diameter in advance of base of head; frontoclypeal suture with a slight raised ridge anterior to deep groove; epistome shallowly emarginate anteriorly ; antennae about 0.75 times length of the body in male, shorter in female; antennae of female with last three segments slightly enlarged to form a loose club, in male these segments more elongate than those preceding but not broadened laterally; disc of head with punctures of two sizes, the larger with diameter equal to slightly more than that of eye facet, the smaller being equal to half or less than this diameter; the larger punctures separated by a distance 
equal to one to two diameters, each subtending a seta equal in length to two diameters ; the smaller punctures irregularly and sparsely scattered between larger; head without microreticulation between punctures but smooth and shining.

Pronotum $\mathrm{I} \cdot 25$ times as wide as long, at its broadest slightly broader than head; anterior angles acute and slightly produced, posterior angles acute; lateral margin with twelve small teeth, those anterior being further separated from each other than those posterior ; puncturation and setation similar to that of head; fovea of lateral line deep.

Elytra at shoulders slightly broader than pronotum ; $2 \cdot 5^{-3} \cdot 0$ times as long as their combined width, hardly narrowing apically; not or only weakly carinate laterally; with three cells weakly developed but hardly visible apically and basally ; striae distinct ; each elytron separately rounded to apico-sutural angle ; without micro-reticulation between punctures.

\section{Congo.}

Holotype male "Dans terreau, au Berlese/Kivu: Terr. Lubero, confl. Munobo et Lubero, I880 m. R. P. M. J. Celis ix-I954" and allotype with the same data (Mus. R. Congo Belge).

\section{Placonotus mestus sp. n.}

This species resembles $P$. dolce sp. n., differing as follows: head and pronotum with punctures separated by once to twice their diameter, without micro-puncturation, with micro-reticulation between punctures at least peripherally on disc; epistome convex anteriorly ; eyes situated very close to thorax; elytra no broader across shoulders than pronotum, markedly narrowing apically, clearly carinate laterally.

\section{Sierra Leone, Congo.}

Holotype male and I5 paratypes "Bas-Uele: Kotell I/2I-i-I925 Dr. H. Schouteden ". Other paratypes: I "Mongende I3-iv-I92I Dr. H. Schouteden "; 3 " Eala viii-I935 J. Ghesquière" ; I "Katanga : Katompe I/I5-vi-I930 Dr. P. Gerard " ; I "Recolté sous écorce d'Hevea Yangambi v-I952 J. Decelle" ; I "Luki 5-xi-I952 R. Mayné R.M.I."; 3 "Yangambi I95I C. Donis z.3-I7, z.802 and z.I368" (Mus. R. Congo Belge) : 2 " Sierra Leone Njala 4-i-I933 E. Hargreaves. Under bark of dead rubber" (British Museum (Natural History)).

\section{Placonotus majus sp. n.}

\section{(Text-fig. 8)}

This species resembles Placonotus tastus sp. n. but differs in that its body colour is less dark, in the possession of the small longitudinal impressions between the

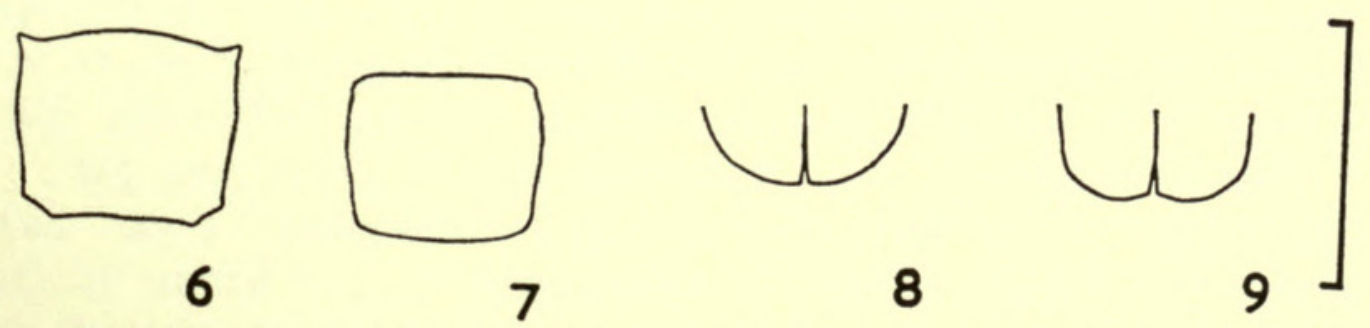

Figs. 6-9. (6) Pronotum of Placonotus tastus and (7) of P. politissimus; (8) elytral apices of $P$. majus and (9) of $P$. subtruncatus.

Scale line $=0.25 \mathrm{~mm}$. 
punctures of the disc of the head and prothorax, in the greater narrowing of the pronotum basally in addition to the emarginate epistome.

$2 \cdot 0-2 \cdot 5 \mathrm{~mm}$.; body ferrugineous in colour.

Head transverse ; eyes about half a diameter in advance of base ; frontoclypeal suture with an anterior ridge and a shallow groove; epistome emarginate anteriorly; antennae about 0.75 times body length in males, shorter in females; disc of head punctured, punctures smaller than facets of eyes, separated by one to three diameters, each with a short seta equal in length to one and a half diameters; surface between punctures irregular, with a tendency to groove-like impressions but otherwise shining.

Pronotum slightly broader than head, about as broad as long at its broadest, narrowed basally ; anterior angles acute and produced, posterior angles obtuse; puncturation and setation on disc similar to that of disc of head; surface micro-reticulate between lateral line and lateral margin ; the fovea included in lateral line shallow but includes a deep puncture.

Elytra as wide as pronotum at widest, slightly more than twice as long as their combined width, carinate laterally, disc concave between carina and suture ; almost parallel-sided until just before apices; apices evenly rounded to apico-sutural angle; cells weakly developed ; striae represented by rows of setae whose subtending punctures are very shallow.

\section{Rhodesia, Congo, Angola, West Africa.}

Holotype and 2 paratypes "N.W. Rhodesia Shigariatombwes, 8-vii-I9I3 H. C. Dollman" (British Museum (Natural History)) ; paratypes as follows : 3 " N.W. Rhodesia Mwengwa $27^{\circ} 40^{\prime} \mathrm{E} 30^{\circ} \mathrm{S}$ 26-vi-I9I3 H. C. Dollman " ; I " Sierra Leone ” (British Museum (Natural History)) ; I "Angola 4I94.5-Alto Chicapa, gal. forest. riv. Ngungo, dans. tronc 27-vi-54. Ed. Luna de Carvalho " ; 2 " Angola 4II6.20Alto Cuilo, Poste de Cacolo, rives de la Cavuemba, detr. sol, 26-v-54. A. de Barros Machado" ; 3 "Angola 4II.6.I7-Dundo, iii-48, piège lumineux. A. de Barros Machado" ; I "Angola 4II8.9-Gal. forest. riv. Lunguena, affl. Luangue, Poste Xa-Cassau, 7-vi-54. A. de Barros Machado "; ir "Angola Io656.42-Marco de Canavezes (Cubal da Ganda), district de Benguela, piège lum; iii-56. Ed. Luna de Carvalho " ; 3 “ Angola 3I58.24-Dundo, xii-53, piège lum. Ed. Luna de Carvalho " ; I3 “ Angola 4895.3-Cazombo, Alto Zambeze, sous écorces arbres morts, I9-i-55. A. de Barros Machado" ; I "Angola 4323.23-Alto Chicapa, gal. forest. riv. Tchirimbo, detr. sol, 9-vii-54. A. de Barros Machado "; 2 "Angola 4II7.I5 -Alto Cuilo, Poste de Cacolo, gal. forest. ruisseau Tcha-Muchito, 2-vi-54. A. de Barros Machado "; I "Angola 4742.I4-Rives du Lac Calundo, sous écorces arbres morts, I9-i-55. A. de Barros Machado" ; 3 "Angola 4737.9 as 4742 . I4 ; 4 “ Angola 3I76. I I-Dundo, ix-53, piège lum. Ed. Luna de Carvalho ” ; 2 " Angola 4359.3-Alto Chicapa, 7-viii-54. Ed. Luna de Carvalho " ; I " Angola 4370.36Alto Chicapa, gal. for. riv. Tchimboma, detr. sol, I7-i-55. A. de Barros Machado ” ; I" Angola 42I4.42-Alto Chicapa, gal. forest. riv. Ngungo, detr. sol, 27.vi.54. A. de Barros Machado" ; I “Angola 3II5.2I-Dundo, viii-53, piège Lum. Ed. Luna de Carvalho " (Museu do Dundo) ; 2 “ Yangambi I95I C. Donis 300, 302 ” ; 3 “ Luki I95I P. Henrard 97 ” ; II “ Eala vii-viii-I935 J. Ghesquière ” ; 24 " Eala iii-I935 J. Ghesquière " ; 3 "Eala X-I936 J. Ghesquière " ; 2 " Kindu L. Burgeon " ; I " Stanleyville I9-viii-I928 A. Collart " ; I " Kamajembi (Luebo) 2I-ix-I92I Dr H. Schouteden " ; I “Malych I942 Rev. P. Van Eyen ” ; I " Katang: Kanzenge I2544 N. Leleup I2-ii-I949” ; I “ Tanganyika : Moba, 780 m (à la lumière) xi-I953 
H. Bomans " (Mus. R. Congo Belge) ; 23 “IFAN I953 Bafrechie (Mauritanie) 5-ix to Io-x A. Villiers" ; I3 "IFAN I946 Mr Nimba N.E. 500-700 m. A. Villiers"; 2 "Irabellaben Mrs Baguezans I200-I300 m 28-3I-viii IFAN I947 L. Chopard, A. Villiers ” (Muséum National d'Histoire Naturelle, Paris).

\section{The subtruncatus Species Group}

There are three species involved in this group, $P$. subtruncatus sp. n., $P$. ealaensis sp. n. and $P$. africanus sp. n. It has not been possible to separate these species on invariable external characters but there are no difficulties in seeing the differences between the male genitalia. Externally, the three species resemble P. tastus sp. n. but differ from it in that the body is yellowish brown in colour and in the tendency to longitudinal impressions on the surface of the head between the punctures.

\section{Placonotus subtruncatus sp. $\mathrm{n}$.}

(Text-figs. 9, II)

$2 \cdot 0-2 \cdot 5 \mathrm{~mm}$.; body yellowish to reddish brown in colour.

Head transverse ; eyes a quarter to a half times their diameter in advance of base of head, hemispherical in shape ; frontoclypeal sutural region with anterior shallow transverse impression consisting of a ridge and a deeper groove ; epistome emarginate anteriorly; antennae about $0 \cdot 75$ times body length in males, fifth to eleventh segments about twice as long as broad, in
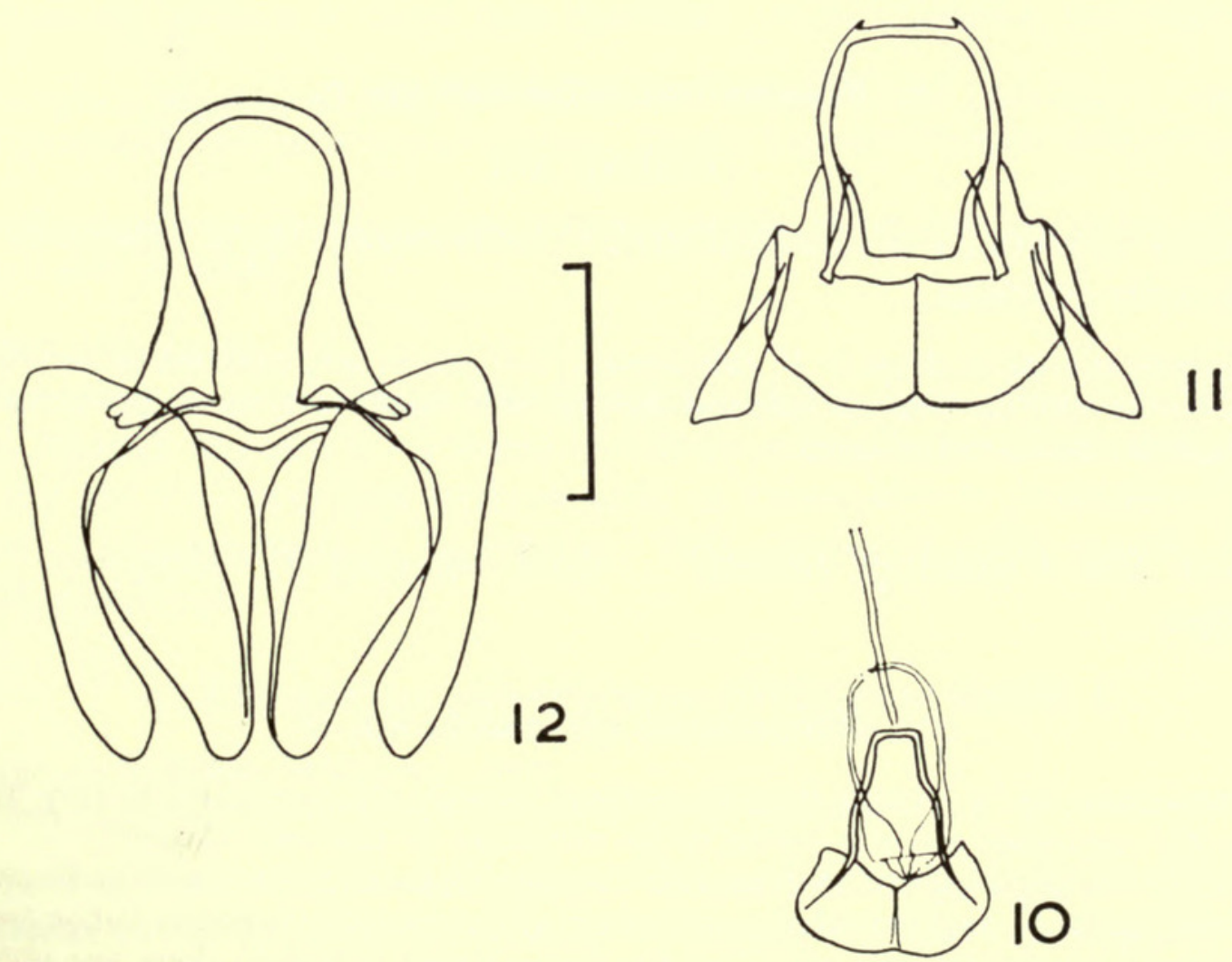

FIgs. I0-12. Male claspers of (Io) Placonotus ealaensis, (I I) P. subtruncatus and (I2) $P$. africanus.

Scale line $=0.25 \mathrm{~mm}$. 
females antennae about 0.6 times body length, fifth and subsequent segments about $\mathrm{I} \cdot 5^{-2 \cdot 0}$ times as long as broad; in both sexes, last three segments slightly dilated, more distinctly so in female ; disc of head punctured, the punctures slightly smaller than facets of eyes, separated by once to three times their diameter, each with a fine seta equal to $\mathrm{I} \cdot 5$ times this diameter in length ; surface between punctures polygonally reticulate but generally shining.

Pronotum slightly broader than head (including the eyes), very slightly broader than long at its broadest, narrowed basally; anterior angles acute and produced, posterior angles obtuse ; disc ornamented similarly to disc of head ; fovea included in lateral line encroaches upon disc, moderately deep and often includes a deep puncture and blackish mark.

Elytra slightly broader than pronotum, broadest just anterior to mid-point, about $2 \cdot 25$ times as long as their combined width, abruptly deflected laterally but not carinate at fold; each elytron separately and abruptly rounded to apico-sutural angle; cells weakly developed, strial punctures shallow.

Ventral claspers of male genitalia straight posteriorly with three irregular dorsal rows of small tubercles posteriorly, in shape resembling a coal hammer ; dorsal claspers not completely divided in mid-line, less strongly chitinized medially than laterally, together of shape appropriate to a normal tenth tergite, ventral surface with four irregular rows of tubercles posteriorly ; both dorsal and ventral claspers in length equal to fifth externally visible abdominal sternite.

Congo, West Africa.

Holotype male and 8 paratypes: "Nioka xii-53. P. Deville Pap. 49 ”; other paratypes as follows : 4 as holotype but dated 26-xii-53 and Pap 47, I with Pap. 46, I dated 28-xii-53 and Pap. 68 ; I " Katanga. Katompe I/I5-vi-I93o Dr. P. Gerard" (Mus. R. Congo Belge) : 2 "IFAN-I946 Tonkoui C.I. 900-I200 m. A. Villiers Forêt Prim. 20/30-ix” (Muséum National d'Histoire Naturelle, Paris).

\section{Placonotus ealaensis sp. n.}

(Text-fig. Io)

This species appears to be identical with $P$. subtruncatus sp. n. except in the structure of the male genitalia.

Dorsal claspers similar to those of $P$. subtruncatus but less evenly rounded externally ; ventral claspers hardly developed, being a thin rod on each side apparently fused posteriorly with the external angles of the dorsal claspers.

Congo.

Holotype and I paratype (males): "Eala viii-I935 J. Ghesquière" (Mus. R. Congo Belge).

\section{Placonotus africanus sp. $\mathrm{n}$.}

As $P$. subtruncatus sp. n. except that the surface between the punctures is very weakly, if at all, polygonally reticulate and also differs in the structure of the male claspers :

Dorsal claspers completely divided medially except, apparently, for a thin transverse strut anteriorly, narrowed posteriorly where no wider than ventral claspers; tubercles on dorsal claspers arranged in two groups, one irregular row running forwards along the lateral margin from posterior region until just before anterior margin ; other tubercles about twenty in number situated in a group antero-medially; ventral claspers spatulate posteriorly, situated lateroventrally, bearing about twenty-five long spines internally. 
Congo, Angola.

HoLotype male "Katanga: Kanzenze (a même l'argile sous bois pourri) I2544 N. Leleup I2-ii-49"; paratypes as follows: I "Katanga : Kansenze 22-xi-I948 I2625 N. Leleup "; I " Recolté dans l'humus. Distr. Elisabethville Gal. for. de la Kisanga 26-ix-5I N. Leleup "; 4 "Elisabethville 6-X-I9I2 Miss. Agric."; I "S/Bois divers Kasai : Kakenge Seierie Exforka i-I945. J. Vrydagh " ; Io " Eala iii-I935 J. Ghesquière 376" (Mus. R. Congo Belge) ; I8 “ N.W. Rhodesia Shigariatombwes 8-vii-I9I3 H. C. Dollman" ; I "Angola 3I76. II-Dundo, ix-53, piège lum. Ed. Luna de Carvalho" ; 2 "Angola 4II7.I5-Alto Cuilo, Poste de Cacalo, gal. forest ruisseau Tcha-Muchito, 2-vi-54. A. de Barros Machado" ; I "Angola 4II9.3-Alto Cuilo (Cacalo), vi-54. A. de Barros Machado et Ed. Luna de Carvalho "; I "Angola 4373.9-Rives du Lac Calundo, sous écorces arbres morts, I9-i-55. A. de Barros Machado" ; I "Angola 4895.3-Cazombo, Alto Zambeze, sous écorces arbres morts I2-ii-55, Ed. Luna de Carvalho"; I "I8 m. S.W. of Elizabethville 3I-X-I927 Dr. H. S. Evans" (British Museum (Natural History)).

\section{Placonotus donacioides (Wollaston) comb. $\mathbf{n}$.}

Laemophloeus donacioides Wollaston, I854.

Laemophloeus granulatus Wollaston, 1854, syn. $\mathbf{n}$.

Head very slightly transverse in males, as broad as long in females; epistome shallowly emarginate anteriorly; lateral line represented by raised ridge and an internal groove which includes a weakly impressed line ; surface punctured, punctures slightly larger than the facets of eyes, separated by once to twice their diameter; surface between punctures polygonally reticulate.

Pronotum about as broad as long, narrowed both anteriorly and posteriorly ; anterior angles acute and produced, posterior angles obtuse; lateral line and surface ornamentation as that of head.

Elytra with three cells developed, secondary intervals about half the width of cells; strial punctures almost invisible.

Madeira, Canaries.

There are 2 specimens without data labelled as types by G. Arrow in the Wollaston collection (British Museum). I select the male as lectotype of the species.

There are also two syntypes without data of Laemophloeus granulatus in the same collection. I select a male as lectotype. This species is quite clearly just a small form of $P$. donacioides.

\section{Placonotus politissimus (Wollaston) comb. n.}

Laemophloeus politissimus Wollaston, 1867.

Laemophloeus (Silvanophloeus) mirus Grouvelle, I905, syn. n.

This species, when described by Grouvelle, was considered to be very simila: to Laemophloeus nitens Leconte (this American species properly belongs to Placonotus and is now placed in that genus comb. n.). The two species were distinguished by the presence of femoral lines on the first visible sternite of the abdomen of $P$. politissimus. In addition it has been found that no other species of the genus from 
Africa possesses femoral lines and thus this feature serves as an adequate distinguishing character.

$\mathrm{I} \cdot 5^{-2} \cdot \mathrm{O} \mathrm{mm}$; body yellow to reddish brown in colour.

Head transverse; eyes large and situated close to base ; frontoclypeal suture with shallow groove and without raised ridge anteriorly ; epistome emarginate anteriorly ; antennae about three-quarters length of body in males, somewhat shorter in females, distal three segments very slightly dilated in males, a little more so in females; disc of head very evenly punctured, punctures separated by about two to four diameters, each puncture with a seta about $1 \cdot 5$ diameters in length; intervals between punctures smooth and shining.

Pronotum transverse, about I.25 times as wide as long, slightly broader than head ; broadest across anterior third; anterior angles obtuse and rounded, posterior angles rectangular to slightly obtuse; puncturation and setation as on head; fovea of the lateral line apparently formed by fusion of three large shallow punctures.

Elytra broader across shoulders than pronotum at its widest, broadening slightly before midpoint and then narrowing towards apices, each evenly rounded to apico-sutural angle ; at their extreme length, between suture and external angle, elytra about twice as long as their combined width; only the third cell is developed basally together with part of the first near mid-point and close to suture; each elytron with inflected lateral region but not carinate; striae with punctures considerably larger than those of head and pronotum.

The species exhibits marked heterogony in the adult structure in addition to some variation in size and puncturation.

Atlantic islands off Africa, Congo, Ivory Coast, Madagascar, Seychelles.

There are eleven specimens in the Wollaston Cape Verde collection in the British Museum and two further specimens with a $\beta$ written on the card standing in the position indicated by the species name. One of the eleven has a British Museum type label and a second label with " politissimus, Woll " in Wollaston's handwriting. In his original description Wollaston writes that the species was taken "in profusion "; it would seem likely that these eleven specimens are all, or at least some, of the syntypes. I now select the labelled specimen, a male, to be lectotype. Of the remaining specimens, ten are the same species; the specimens labelled $\beta$ on the card are Cryptolestes capensis (Waltl). Wollaston, in discussing Laemophloeus clavicollis Woll. immediately after describing L. politissimus, refers to a "var. $\beta$ affinis" and since L. clavicollis is C. capensis (see p. 235), I presume that these two specimens are misplaced in the collection and are not to be considered as syntypes of L. politissimus.

Grouvelle, in his original description of Laemophloeus mirus gave the following type localities: "Fort-Dauphin (coll. Alluaud) ; localité incertain (coll. A. Grouvelle); St-Thomé (coll. A. Grouvelle)". In the Grouvelle collection in Paris, there are the following specimens of the species; one "Madagascar [mss]/Type [black printed on white]/Laemophloeus mirus Grouv. ty [in Grouvelle's mss]/ Type [black printed on red]" ; one "Madagascar (Sud) Forêt Nord Ft. Dauphin Alluaud I900 [printed] I7 [mss]". In addition there are six specimens from Amani and one from the Cape of Good Hope which are obviously not syntypes. I have not located a specimen from St. Thomé in the Grouvelle collection either named as this species or unnamed but referable to it. I consider that the two specimens of the species whose detailed data are given above are syntypes and I now select the specimen which bears Gruovelle's mss label as lectotype. The 
other specimen is the same species. It is quite clearly the same species as $P$. politissimus.

The author has seen specimens of the species from the following places: Yangambi, I95I (C. Donis), Lubilonga, ii.52 (M de Backer), Luki, vii.42 (R. Mayné), Luki, I95I (P. Henrard), Elizabethville, ii. I940 (H. J. Bredo), Kunungu, 9.iv. I92I (Dr. H. Schouteden), Eala, ix.I938 (J. Ghesquière). Elizabethville-à la lumière, xi.50/vi.5I (Ch. Seydel), Mobeka, I6.iii.rgII (L. Burgeon) all within the Congo; I "Madagascar Namoroka xi.52 R. P(aulian)" ; I " Seychelle Islands Percy Sladen Trust Expedition/Mahe I908-9" ; I " Madagascar (Sud) Forêts Nord Ft. Dauphin Alluaud I9oo (I7)" ; I " Haut Côte d'Ivoire, Danaue (Fort Hittos) A. Chevalier I9Io, Avril "; I " Madagascar Perrier".

\section{Io. Placonotus bolivari (Grouvelle) comb. $\mathbf{n}$.}

Laemophloeus bolivari Grouvelle, 1905.

$\mathrm{I} \cdot 75^{-2} \cdot 25 \mathrm{~mm}$. ; body shining, yellowish red in colour, elytra much more yellow and almost transparent.

Head very transverse, about twice as broad as long; eyes situated in advance of base ; head turning abruptly medially just anterior to antennae and anteriorly again at lateral end of frontoclypeal suture ; suture evenly rounded; epistome truncate ; antennae as long as or slightly longer than body in males, about 0.75 times length of body in females; scape robust and about equal in length to second and third segments combined in males, somewhat shorter in females; distal segment slightly curved in male, straight in the female, in female last three segments slightly enlarged forming a loose club ; disc of head regularly punctured with irregularly shaped small punctures, punctures separated by a distance equal to two eye facets, each with a very short seta ; intervals between punctures rather shining and with very fine micro-punctures.

Pronotum very slightly broader than head at its broadest, $\mathbf{I} \cdot 2$ times as broad as long, broadest at about anterior quarter ; anterior angles ventral in position since anterior half of region between lateral line and lateral margin inflected ventrally ; angles obtuse and slightly produced ventrally, posterior angles rectangular or very slightly produced; lateral line consisting of a groove, expanding from about the mid-point to a maximum at included deep puncture, narrowing towards basal fifth; secondary raised line present basally between primary line and lateral margin ; disc with puncturation and setation as on the disc of head.

Elytra about twice as long as their combined maximum width which is at about their midpoint, there broader than pronotum, narrowing slightly until external apical angles, then turning more or less abruptly to sutural angle; thus each elytron subtruncate; cells not developed; striae distinct; elytra apparently glabrous except for a few larger setae apically; abdomen only slightly exposed dorsally.

\section{EAst and West Africa, Congo.}

Holotype " Biafra Cabo S. Juan viii-rgor Escalera/Type/I5/L. Bolivari Grouv. ty.” (Grouvelle coll). There are eight other specimens standing next to the type of this species all collected in S. Thomé, their data labels being written in differently coloured inks suggesting that they were acquired by Grouvelle at different times. The specimen collected by Escalera is the only one to bear the word type in Grouvelle's handwriting although three of the others have a printed label with the word type in addition to the locality label. I do not accept the S. Thomé specimens as syntypes and consider that the Escalera specimen is the holotype. Other specimens seen include 2 "Luki I950 R2306 Com. et Bois Coll. R. Mayné" ; 4 "Yangambi, 
I95I C. Donis z.304, 32I, 323, and 326 Coll. R. Mayné Com. et Bois Congo R. 2326" ; I "Haut-Uele: Moto x-xi-I923 L. Burgeon" ; I "Mayumbe. Pulu-Banzi I7-iiI924 A. Collart" ; I "Ubangi : Gemena 3-i-I936 C. Leontovitch" ; 2 "Yangambi 3-vii-I952 Dr. Schedl s.295" (Mus. R. Congo Belge); 2 "St. Thomé" ; I "Ed. Luga Kondie Congo Belge" (Muséum National d'Histoire Naturelle, Paris).

\section{Placonotus decoratus (Grouvelle) comb. n.}

Laemophloeus decoratus Grouvelle, I908.

This and the next species are the most distinct of African Laemophloeinae and certainly the most distinct Placonotus. P. exornatus (see below) differs in having the head, pronotum and the greater part of the elytra brown and not black as $P$. decoratus.

Since Grouvelle's description is quite adequate, the species will not be fully redescribed.

$\mathrm{I} \cdot 75^{-2 \cdot 3} \mathrm{~mm}$; ; body shining; mouthparts, basal segments of antennae, tibiae and tarsi dark brown; femora, head, pronotum and the greater portion of each elytron black; elytra otherwise yellow in a region at anterior third from about second or third strial interval to lateral margin. Elytra truncate, external apical angle being somewhat more distinct than usual; last segment of abdomen almost entirely exposed dorsally ; in male paired accessory structures of genitalia often exposed.

The lectotype, which I now select, is in the Grouvelle collection in Paris and bears the following data: "Af. or All Amani/Eichelbaum/Type/Laemophloeus decoratus sp. nv. Grouv." The other syntype in the same collection bears identical data except that it does not bear the name of the species in Grouvelle's handwriting.

South Africa, Congo, Kenya.

The author has seen specimens as follows: 2 "E. Cape Prov., Katberg $4000 \mathrm{ft}$. xii-I932 R. E. Turner” ; I “ E. Cape Prov., Katberg 4000 ft. I3-I5.iii-I933 R. E. Turner" (British Museum (Natural History)) ; 23 "Ruanda: Kayove $2000 \mathrm{~m}$. terr. Kisenyi P. Basilewsky I4-ii-I953"; I " Manyema I9I8 Sibatwa Kilengwe Dr. Gerard" ; I "Forêt de bambous et Podocarpus Kenya : Elgon, Vers. Est. 2500 m. (dans humus) N. Leleup 4-xii-I953" ; 2 " Nioka xii - I953 F. Deville Pap. 49/Com. et Bois Congo R. 2507" (Mus. R. Congo Belge) ; I “ O A Nandi Reservat leg. Alinder" (Munich).

\section{I2. Placonotus exornatus (Grouvelle) comb. n.}

Laemophloeus (Silvanophloeus) exornatus Grouvelle, 1908.

It has not been possible to find any external difference between this and the previous species except in their colour; it is therefore possible to confuse immature $P$. decoratus with $P$. exornatus. This difference in colour may indicate that the two species are not really distinct since $P$. exornatus is only known to the writer by two specimens. It may be possible to show that the two species are in fact synonymous if $P$. decoratus is found together with $P$. exornatus in South Africa and the specimens of $P$. exornatus are kept alive and observed to see whether they 
change colour with time. A similar colour difference between two species of otherwise identical Cryptolestes was found to reflect a specific difference (Lefkovitch, I959a).

South AFrica.

Grouvelle's original description was based upon a single male bearing the following data: "C. B. Ep. Donkis/Port Alfred/L. exornatus ty. Grouv." The author has seen a second specimen with the following data: "Port St. John Pondoland Nov. I923/S. Africa R. E. Turner” (British Museum (Natural History)).

\section{I3. Placonotus mossus sp. n.}

This species most resembles $P$. donacioides (Woll.) in that the nature of the microsculpture on the head and pronotum and the consequent dull appearance distinguish these two species from other Placonotus. These two species can be distinguished easily in that $P$. donacioides is relatively longer in its build and possesses punctures on its head in addition to the reticulation.

I. $8 \mathrm{~mm}$.; head and pronotum reddish brown, rather dull, elytra yellow and transparent.

Head transverse ; eyes situated about half a diameter in advance of base ; epistome shallowly emarginate; frontoclypeal suture with a groove the anterior margin of which is raised slightly. evenly rounded posteriorly; antennae in male with segments longer than broad, becoming progressively longer after third ; scape the most robust segment ; antennae in total length just reaching apices of elytra ; disc of head impunctate but strongly reticulate into polygonal areas, three of these areas being slightly greater in area than an eye facet; without setae on disc.

Pronotum distinctly transverse, about $\mathrm{I} \cdot 25$ times as broad as long; broadest at about midpoint; distinctly broader than head; distance between anterior angles only just perceptibly greater than that between posterior angles ; anterior angles acute and projecting, lateral margin just posterior to them evenly sinuate, not abruptly so as in most Placonotus; posterior angles obtuse; lateral line expanded somewhat just behind mid-point to accommodate the deep puncture or fovea ; surface of disc otherwise impunctate but reticulate as on head ; glabrous.

Elytra broadest at anterior third, there as broad as pronotum; narrowing from this region to apices, each elytron separately rounded to apico-sutural angle ; elytra just twice as long as their combined width ; three cells present basally, outer margin of third continues further posteriorly than others ; striae more or less visible, apparently without setae. Legs somewhat shorter than is usual for the genus.

Female unknown.

Congo.

Holotype male "Yangambi I952 C. Donis z.2978 Com. et Bois Congo R.2440" (Mus. R. Congo Belge).

\section{XYLOLESTES gen. $\mathrm{n}$.}

Type species : Laemophloeus unicolor Grouvelle.

This genus is most closely related to Xylophloeus gen. n. which is described below. It resembles some species of that genus more closely than others, especially Xylophloeus patens (Grouvelle). The key to genera and the table on p. Igo outline the most important differences.

I.5-2.5 mm.; body moderately flattened.

Head distinctly transverse ; eyes situated about half their diameter in advance of base, occupying slightly more than one-third of lateral margin; antennae inserted at about front 
corners of head and equal to half body length; with last three segments more transverse and enlarged to form a distinct club ; epistome apparently straight but in fact with three shallow emarginations ; lateral line represented by a groove on each side, joined anteriorly by a transverse groove situated just behind epistome; frontoclypeal suture obsolete ; labrum parallelsided and truncate to distinctly emarginate anteriorly.

Pronotum transverse, with rounded anterior and obtuse posterior angles ; lateral line represented by a distinct groove; basally a slight ridge and a shallow groove running laterally from lateral line to hind angle; lateral lines joined anteriorly but not posteriorly by a groove.

Scutellum triangular with rounded angles; elytra normally covering whole abdomen; the three cells clearly defined, posterior border of first and borders of third much more clearly defined than others which may be obsolescent; each elytron distinctly carinate laterally, the carina lying close to outer margin of third cell after basal third.

Genae normal ; gular sutures distinct; anterior coxal cavities narrowly open posteriorly, with distinct lateral extension ; intercoxal process of the prosternum slightly concave posteriorly ; mesepimeron only just reaching mesocoxal cavities; posterior margin of mesosternum slightly concave; metasternum about equal in length to first and second visible abdominal sternites combined (Text-fig. I3) ; median metasternal line not reaching the anterior margin of sclerite; first visible abdominal sternite about $\mathrm{I}_{5} 5$ times as long as second, second to fifth about equal to each other; legs subequal; trochantero-femoral junctions of normal type; tarsal formula 5-5-5 (in both sexes).

\section{Xylolestes unicolor (Grouvelle) comb. $\mathbf{n}$.}

(Text-fig. I4)

Laemophloeus unicolor Grouvelle, 1908.

This species was described by Grouvelle only in his key, to which the above reference relates, as " unicolor Grouv. Afrique or. all." Fortunately, it can be recognized as a distinct and not uncommon species in Africa. The species is redescribed below.

I.5-2.75 mm.; body reddish brown in colour, elytra more yellow than head and pronotum, tarsi and antennal club yellow.

Head transverse, trapezoidal in shape ; antennae just reaching basal quarter of elytra, fourth to eighth segments as wide as long, segments one to three more elongate, at most twice as long as wide; last three segments about I.5 times as broad as eighth and except for last segment, I' 5 times as long as eighth; last segment about twice as long as broad and shaped rather like an egg; disc of head irregularly punctured with irregularly shaped punctures, these smallest and most nearly circular near mid-line, largest half-way between mid-line and lateral line; the largest punctures somewhat larger in diameter than facets of eyes ; surface of head shining between punctures ; with sparse, very fine setae which are often not easily visible.

Pronotum twice as wide as long, broadest in front of middle where thorax $I \cdot I-I \cdot 25$ times as wide as head across and including eyes ; anterior angles rounded, posterior obtuse ; puncturation on disc finer than on head; setation as on head.

Elytra across shoulders as broad or broader than pronotum, slightly more than twice as long as their combined width, roughly oval in shape; broadest at about anterior third, there about I.25 times as broad as pronotum; thinner darker areas of elytra are arranged in rows and probably represent striae; apparently glabrous.

There are two syntypes of this species in the Grouvelle collection, one with data "Zanzibar Raffray/Laemophloeus unicolor Grouv ty" and the other "Af.or. All. Amani/Eichelbaum/Type [mss] " and a Paris museum type label. I now select the first of these specimens to be lectotype. 
East and West Africa, Congo, Angola.

I have examined the following specimens of the species: I "Nioka 27-ii-54 F. Deville Pap. 57 R.2507"; I "Yangambi, I95I z.26I R. 2333"; 7 "Coquilhatville 27-viii-I930 J. Vrydagh "; 2 "Eala vii-I935 J. Ghesquière " ; 2 " Potopot près Dima 4-ix-I930 G. F. de Witte"; 2 "Ituri: La Moto: Madyu L. Burgeon "; I "Equateur: Flandria xi-I929 R. P. Hulstaert "; I " Haut Uele, Walsa, xi-Igr9 L. Burgeon"; I "Recolté dans l'humus/Kivu: T. Fizi, Bas Itombwe rooo m. (Gal. for. Mukera) N. Leleup ii-52" ; I " Kwamouth vi-I92I Dr. H. Schouteden" ; I "Isangi I929 J. Walkiers" ; I "Lulua ; Kapanga viiI932 G. F. Overlaet " Miss. H. de Saeger : I (2062) ; I (2II5) ; I (3563) ; I (3744) (see Appendix) (Mus. R. Congo Belge), I " Angola I253.II.2. Dundo, galerie forestière Luachimo, sous écorces arbres tombes, xii-48 A. de Barros Machado " (British Museum (Natural History)) ; 22 " IFAN-I946 Tonkui C.I. 900-I200 m. A. Villiers " ; I "Amani "; I "Côte d’Ivoire Bimbroko"; I "S. Thomé (Muséum National d'Histoire Naturelle, Paris).

\section{XYLOPHLOEUS gen. n.}

Type species: Laemophloeus patens Grouvelle.

This genus resembles the previous in several ways; it can be distinguished by the characters given in the key to genera on p. I72 but especially by those given in the tabulated comparison with Xylolestes (p. I90).
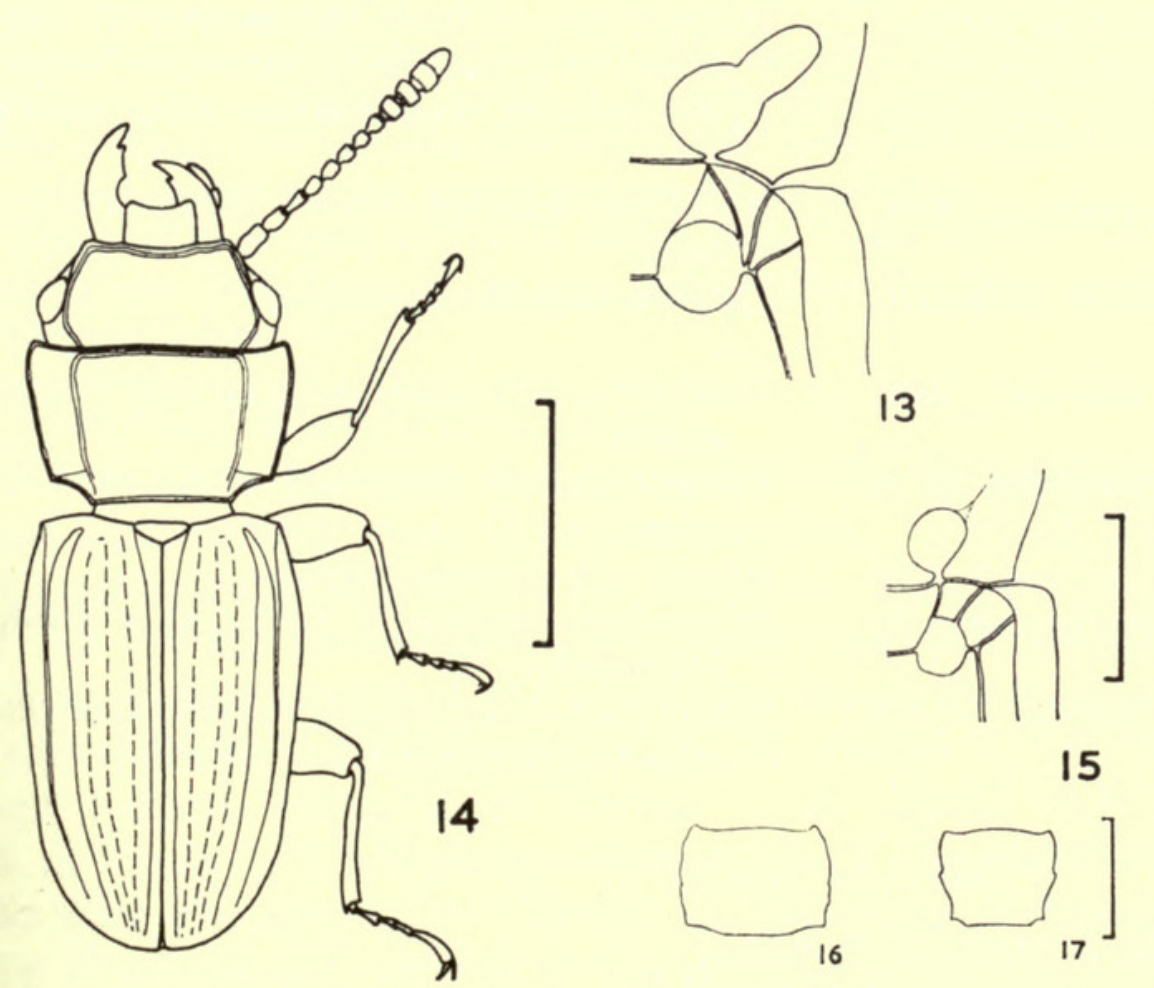

15
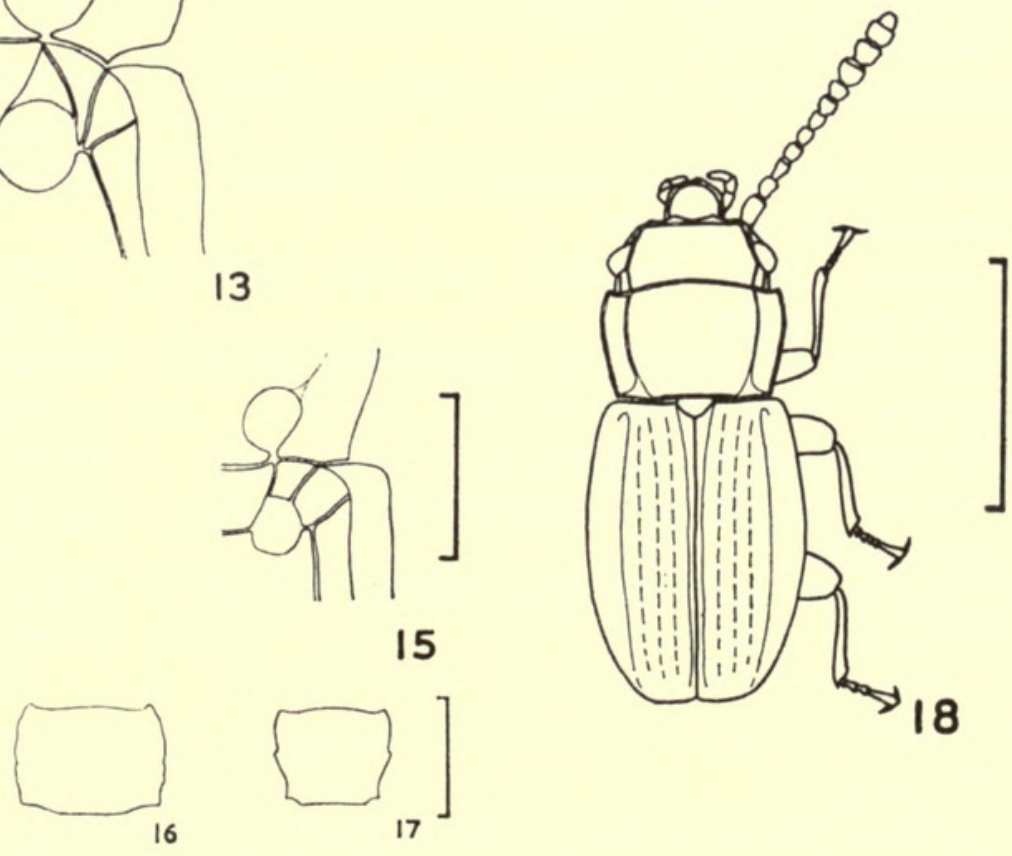

Figs. I3-I8. (I3) Front and middle coxal cavities of Xylolestes unicolor ; (I4) dorsal view of X. unicolor; (I5) front and middle coxal cavities of Xylophloeus patens; (I6) pronotum of $X$. bimaculatus and ( $\mathrm{I} 7$ ) of $X$. unifasciatus ; ( 18 ) dorsal view of $X$. patens. Scale lines: Figs. I3, I5 $=0.25 \mathrm{~mm}$. ; Figs. I4, I6, I7, I $8=\mathrm{I} \mathrm{mm}$. 
2.5 mm.; body moderately flattened.

Head transverse and rectangular in its general appearance; lateral lines distinct and forming part of dorsal margin of eye, joined anteriorly just behind epistome by an almost straight ridge ; epistome with three emarginations ; antennae inserted just behind front corners of head, their segments (except for scape and pedicel) slightly transverse, last three forming a loose club ; frontoclypeal suture obsolete although depressions corresponding with this and with median line can be seen if the incident light is at the correct angle ; eyes situated in advance of base of head; labrum rounded anteriorly.

Pronotum transverse, somewhat cordiform ; anterior and posterior angles acute ; lateral line represented by a ridge raised above the general surface ; internal to lateral line often a row of small punctures situated very close to lateral line, somewhat more distinct behind mid-point ; externally to lateral line a shallow circular fovea situated at about mid-point, diameter of which about equal to distance separating line from margin.

Scutellum triangular, slightly transverse ; elytra with three cells developed although lateral margin of third obsolescent just after base ; no lateral carina present but lateral region evenly deflected ventrally from inner border of third cell.

Genae normal; gular sutures distinct; anterior coxal cavities slightly open posteriorly ; anterior coxae spherical and well separated ; intercoxal process of prosternum straight posteriorly; metepimeron not contributing to mesocoxal cavity but mesepisternum and mesepimeron contribute equally, forming together about one-third of circumference of cavity (Text-fig. I5) ; metasternum equal in length to first two visible abdominal sternites; first abdominal sternite twice as long as second, its intercoxal process straight anteriorly ; second sternite slightly longer than either third or fourth, the fifth about equal to or slightly longer than second.

Legs subequal; trochantero-femoral junctions of normal type ; tarsal formula 5-5-5 in female, 5-5-4 in male.

\section{Xylolestes gen. $\mathbf{n}$.}

Lateral lines of head represented by groove joined anteriorly by a transverse groove

Epistome apparently straight but with three shallow emarginations

Antennae inserted at front corners of head

Labrum parallel-sided, truncate to distinctly emarginate anteriorly

Prothorax with rounded anterior and posterior angles

Lateral line of pronotum represented by a groove

Each elytron carinate laterally

Intercoxal process of prosternum concave posteriorly

Mesepimeron just reaching middle coxal cavities

\section{Xylophloeus gen. $\mathbf{n}$.}

Lateral lines of head represented by ridges, joined anteriorly by a transverse ridge.

Epistome with three distinct emarginations.

Antennae inserted behind front corners of head.

Labrum rounded anteriorly.

Prothorax with acute anterior and posterior angles.

Lateral line of pronotum represented by a ridge.

Elytra not carinate laterally.

Intercoxal process of prosternum straight posteriorly.

Mesepimeron and mesepisternum contribute equally to middle coxal cavities.

\section{Key to Species}

I. Pronotum at widest as wide as elytra at shoulders

- Pronotum at widest narrower than elytra at shoulders

2. Pronotum hardly broader than long $(\mathbf{I} \cdot \mathbf{I}$ times) ; disc of pronotum convex

- Pronotum transverse $(\mathrm{I} \cdot 3-\mathrm{I} \cdot 5$ times as broad as long); disc of pronotum flat

3. Pronotum unicolorous yellow; elytra coloured as pronotum r, patens (Grouvelle) (p. I9I) 
- Pronotum darker in colour on disc between lateral lines than outside ; elytra with dark markings

4. Pronotum entirely black .

- Pronotum red or yellow, at least in part

5. Elytra black but for the humeral angles which are dark red in colour

7. dentatus $\mathrm{sp} . \mathrm{n}$. (p. 194) 3. chrysomeloides sp. n. (p. I92)

- Elytra entirely yellow or with a dark maculation on each

4. elgonensis sp. n. (p. I93)

6. Hind angles of pronotum slightly acute ; disc of pronotum almost black ; distance between hind angles of pronotum equal to or slightly more than that between the front angles (Text-fig. I6) . . . . . . 6. bimaculatus $\mathrm{sp}$. n. (p. I93)

- Hind angles of pronotum obtuse ; disc of pronotum hardly if at all darker than the lateral region; pronotum narrower between the hind angles than between the

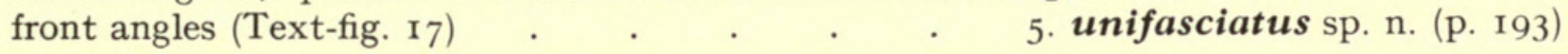

\section{Xylophloeus patens (Grouvelle) comb. n.}

(Text-fig. I5)

Laemophloeus patens Grouvelle, 1908.

$2 \cdot 0-2 \cdot 25 \mathrm{~mm}$.; yellowish brown in colour, elytra almost transparent.

Head with front region at slightly lower level than rest (? frons) ; lateral line formed by ridge and groove; secondary line present behind eye; antennae reaching to basal third of elytra, third segment slightly elongate ; disc evenly punctured, punctures equal to or slightly smaller than facet of eye, separated by one to three diameters, with fine setae about equal to three diameters in length.

Pronotum $\mathrm{I} \cdot 7$ times as wide as long at maximum width, which varies from about mid-point to just behind anterior angles ; at maximum width prothorax very slightly broader than head ; lateral lines formed by slightly raised ridge, occasionally not joined by transverse line posteriorly ; anterior angles produced further anteriorly than greater part of anterior margin of pronotum, acute in shape but extreme apices rounded ; posterior angles sharp and acute-angled ; puncturation and setation on disc similar to that on disc of head.

Elytra of maximum width at about basal third, there $\mathrm{I} \cdot 25$ times as broad as pronotum; slightly less than twice as long as their combined width; punctured striae present but elytra apparently glabrous.

South and East Africa, Congo.

There are 2 syntypes of the species in the Grouvelle collection; I select as lectotype a male which bears the following data: "Af. or. All Amani/Eichelbaum/Type/ 3g/Laemophloeus patens n.s. ty. Grouv." The data of the paralectotype are "Af. or. All. Amani/Eichelbaum/Type [mss] " and a Paris museum type label.

I have also examined the specimens whose data are given below : 3 " Zululand: Eshowe. 6-3I-V-I926 S. Africa R. E. Turner"; 9 "Port St. John, Pondoland. Sept I923 S. Africa R. E. Turner "; I " Natal, near Durban (Virgin bush), IoI8. xii.I904 " ; I " Malvern, Natal G. A. K. Marshall-viii-I897" (British Museum (Natural History)) ; I " Forêt de transition/Tanganyika Terr: Uluguru Mts., val. Ullulu-Ndogo, I500 m. 8-v-I957/Mission Zoolog. I.R.S.A.C. en Afrique orientale (P. Basilewsky et N. Leleup)" ; I "Forêt de montagne/Tanganyika en Afrique orientale (P. Basilewsky et N. Leleup) " ; 2 " Tanganyika Terr : Mt. Oldeani, Versant Est, for. bamb. 2350-2500 m. 6/9-vi-57/P. Basilewsky et N. Leleup " ; I "For. montange/Kivu : Terr. Kabare, S.E. Kahuzi, 2080/2200 m. N. Leleup viii-I95I " ; 
I "Recolté dans l'humus/Kivu: Terr. Uvira, Mulenge I880-20Io m. (Vest. forêt ombroph.) v-I95I N. Leleup ” (Mus. R. Congo Belge).

\section{Xylophloeus mimosae sp. n.}

$3^{\circ} \cdot \mathbf{-}^{\circ} \cdot \mathrm{o} \mathrm{mm}$; ; body rather shining.

Head $\mathrm{I} \cdot 5$ times as wide across eyes than long; eyes situated one diameter in advance of base, their mid-points equidistant from base and antennal insertions; lateral line formed by raised ridge ; secondary line present posterior to eye ; median line visible as a shadow when viewed with lateral illumination; punctures on disc about equal to $\mathrm{I} \cdot 25$ times diameter of eye facet; separated by 2-4 times diameter of puncture, each with seta about equal to two diameters in length ; surface of head between punctures with short impressed lines inclined at an angle to median line and parallel with each other on each side, about equal to two punctures in length ; surface of head between punctures and lines otherwise shining.

Pronotum $\mathrm{I} \cdot \mathrm{I}-\mathrm{I} \cdot 2$ times as wide as long, slightly broader than head, narrowing basally; front angles acute, hind angles acute and projecting; lateral line formed by raised ridge ; lateral margin weakly toothed at posterior border of fovea; puncturation, setation and surface of disc as on head.

Elytra broadest at about middle, there nearly twice as wide as pronotum, about $\mathrm{I} \cdot 75$ times as long as their combined width; each elytron with internal margin of first cell visible apically, separated by striae from the basally visible internal margin of third cell ; each strial puncture with a short seta.

ETHIOPIA.

HoLotype and 4 paratypes (I partially dissected): "Under bark of decaying Mimosa/Djem-Djem Forest nearly 9,000 ft. I-X-I926 Dr. H. Scott ” (British Museum (Natural History)).

\section{Xylophloeus chrysomeloides sp. $\mathrm{n}$.}

2.5 mm.; trophi, epistomal region of the head, first two and base of third antennal segments reddish in colour; remainder of head, pronotum and antennae black, antennae with yellow setae ; elytra yellow but for suture, interstices adjacent to fifth stria and lateral inflected margin brown in colour; striae somewhat darker than interstices; pygidium brown; general surface rather dull.

Head $\mathrm{I} \cdot 5$ times as wide as long; lateral line formed by raised ridge with adjacent row of closely applied punctures; secondary line present posterior to eye; punctures on disc about equal to eye facet in size, slightly smaller behind epistomal ridge, separated by one to three diameters ; surface of head strongly reticulate between punctures.

Pronotum $\mathrm{I} \cdot 25$ times as wide as head, broadest at about anterior third; lateral line formed by a broad, raised ridge and a closely approximated row of punctures, just turning towards centre anteriorly before disappearing and therefore not meeting its fellow behind anterior margin of sclerite ; disc punctured as on head and with a similar reticulation; surface between lateral line and lateral margin reticulate and with few punctures; lateral margin without a tooth near the obsolescent fovea; just before base of disc two very shallow foveae, their centres equidistant from lateral line and lateral margin.

Elytra broadest at mid-point, there about $\mathrm{I} \cdot 75$ times as broad as pronotum; about $\mathrm{r} \cdot 8$ times as long as their combined width; punctured striae somewhat depressed below general level of elytra, each puncture with a seta; surface with longitudinal reticulations between striae, almost micro-rugose ; pygidium coarsely and closely punctured, with long setae. 
Congo.

HoLotype female " Recolté dans l'humus/I.R.S.A.C. Kivu: Terr. Unira, Lubuka 2780 m. (for. bamb.) 4-xi-5I N. Leleup ” (Mus. R. Congo Belge).

Male unkown.

\section{Xylophloeus elgonensis $\mathrm{sp} . \mathrm{n}$.}

This species resembles $X$. mimosae sp. n. but differs in the following particulars: head, antennae, apical and basal regions of pronotum, scutellum, humeral angles of elytra and legs red in colour ; middle region of pronotum, remainder of elytra and pygidium black ; impressed lines between the punctures on discs of head and pronotum more dense and slightly deeper ; elytra across shoulders $I \cdot 3$ times as broad as pronotum at its broadest.

KENYA.

Holotype "Dans feuilles mortes de bambous I.R.S.A.C.-Mus. Congo Kenya: Elgon, Vers. Est. 300 m. II-xii-I953 N. Leleup” (Mus. R. Congo Belge).

\section{Xylophloeus unifasciatus sp. n.}

$$
\text { (Text-fig. I7) }
$$

This species resembles $X$. elgonensis sp. $\mathrm{n}$. very closely in its general shape and differs only in its coloration which is as follows: bases of elytra (except along the suture), apices of elytra and legs yellowish, body otherwise red.

EAst Africa, Congo.

Holotype male "Africa or. Katona/Kilimanjaro X-Igo4" (Természettudományi Muzeum, Budapest) ; paratypes : I " Kivu : Tshibinda xi-I932 L. Burgeon ”; I "Recolté dans l'humus/Kivu: T. Kalehe, 2200 m. Contref. S.O. Kahuzi (forêt de bambous) viii-I95I. N. Leleup"; I "Kivu: Terr. Uvira, Lubuka 2I80 m. (marecage) 3-ix-I95I. N. Leleup ” (Mus. R. Congo Belge).

\section{Xylophloeus bimaculatus sp. $\mathrm{n}$.}

(Text-fig. I6)

3-4 mm.; disc of head and pronotum, middle of each elytron black in colour, remainder of body yellow ; shining and almost glabrous.

Head only slightly broader than long ; antennae with all segments elongate, pedicel shortest ; lateral line formed by raised ridge and internal punctured groove ; secondary line present behind eye; disc punctured, punctures somewhat larger than an eye facet, but somewhat smaller peripherally ; surface of head otherwise smooth and shining except for a few minute punctures between the larger ones.

Pronotum at widest $\mathrm{I}_{5} 5$ times as broad as head, broadest at basal third where lateral margin sinuate ; anterior angles produced, acute but apically rounded ; posterior angles slightly acute ; lateral line formed by ridge and internal punctured groove ; a deep fovea present in sublateral region; disc with punctures as on head; punctures of explanate sublateral region much smaller and very much sparser than those of disc.

Elytra at widest $\mathrm{I} \cdot 5$ times as wide as pronotum, broadest at basal third just anterior to darker markings ; between humeral teeth elytra $I^{*} 4$ times as wide as pronotum ; elytra about $\mathrm{I} \cdot 5$ times as long as their combined width ; not carinate laterally but laterally evenly curved ventrally 
except for extreme lateral region which is explanate; third cell well developed basally, outer margin disappearing before the maculation; elytra striate.

Congo.

Holotype female " Ruanda: Yanina, terr. Klibuye, 2,300 m I2-ii-I953. P. Basilewsky" and I paratype, female " Recolté dans l'humus/I.R.S.A.C. Kivu : Terr. Uvira, Mulenga I880-20ro m. (Vest. for. ombroph.) v-I95I N. Leleup ” (Mus. R. Congo Belge).

\section{Xylophloeus dentatus sp. $\mathbf{n}$.}

3.0-3.5 mm.; trophi, anterolateral regions of head, scape, pedicel, lateral regions of pronotum and elytra, basal region of elytra adjacent to scutellum and median apices of elytra (other than suture) yellow to red in colour, remainder of dorsal surface black; antennae with yellow setae ; moderately shining.

Head about twice as wide as long, less trapezoidal in shape than usual for the genus ; lateral line formed by raised ridge ; a secondary line present behind eye ; disc of head punctured, the punctures of diameter about equal to nearly twice that of eye facet, except near and at median region where they are smaller; separated by distance equal to about half their diameter to twice their diameter; disc of the head polygonally reticulate anteriorly but laterally compressed elsewhere; surface of disc otherwise shining.

Pronotum $\mathrm{I} \cdot 7$ times as wide as long, at widest about $\mathrm{I} \cdot 3$ times as wide as head, broadest at about anterior third and equally broad across lateral blunt teeth situated on lateral margin at the basal third; anterior angles produced, acute in shape but rounded at the extreme apices; posterior angles acute and slightly projecting ; lateral line formed by raised ridge and internal groove, not joined together transversely behind anterior margin; sublateral fovea large in area, encroaching upon ridge of lateral line ; at region of fovea, lateral margin thickened, forming a blunt tooth; lateral region explanate; disc with punctures smaller and further distant than those of head, separated by a distance equal to twice to six times their diameter.

Elytra broadest at basal third, $\mathrm{I} \cdot 7$ times as broad as pronotum, slightly broader across shoulders than pronotum ( $\mathrm{I} \cdot \mathrm{I}$ times); almost twice as long as their combined width; evenly rounded to apico-sutural angle; in longitudinal section elytra sinuate, being concave basally becoming convex at apical third; carinate laterally, lateral margin narrowly explanate.

Kenya, East Africa.

Holotype "Ravin boisé/Tanganyka Terr.: Mt. Meru, Oikokola, versant N.O. 2750 m. 25-vi-I957/Mission Zoolog. I.R.S.A.C. en Afrique orientale (P. Basilewsky et N. Leleup) " (Mus. R. Congo Belge) ; I paratype “ Kidumnik (?) Ukunda [Kenya] ii-I947/Com. Inst. Ent. Coll. No. I0840 ” (British Museum (Natural History)).

\section{BLUBOS gen. $\mathrm{n}$.}

Type species: Blubos matris sp. n.

This genus appears to stand apart from other Laemophloeine genera known to the writer and as such it is difficult to find another genus with which it can be compared. It resembles, at least superficially, some of the species of Xylophloeus gen. $\mathrm{n}$. but differs in many features, the most conspicuous being that the suture between the pronotum and pro-episternum is dorsal in position and not lateral as in that genus.

Head parallel at base, turning outwards just behind eyes ; across eyes head as broad as pronotum; antennae about equal in length to head and pronotum, third segment somewhat longer 
than second, distal three segments slightly enlarged; antennae inserted laterally, behind the apparent front angles of head, insertions somewhat sunken; lateral line on head behind eyes represented by very fine ridge, anterior to eyes this ridge more completely developed; lateral lines joined anteriorly behind epistome by an evenly curved concave ridge ; that part of frons anterior to this ridge evenly emarginate anteriorly, the whole anterior region of head having three emarginations; labrum very slightly emarginate anteriorly, otherwise evenly rounded.

Pronotum transverse, broadest in front of middle ; anterior angles acute, posterior angles acute and produced ; lateral lines represented by groove, its outer margin continuous with anterior and posterior discal margins ; secondary line present basally running medially from posterior angle and turning anteriorly for short distance just before primary line before disappearing ; at about mid-point of lateral region two large, deep punctures or foveae situated between lateral line and lateral margin of pronotum; suture between pronotum and pro-episternum visible dorsally, pro-episternum providing outermost lateral region of prothorax.

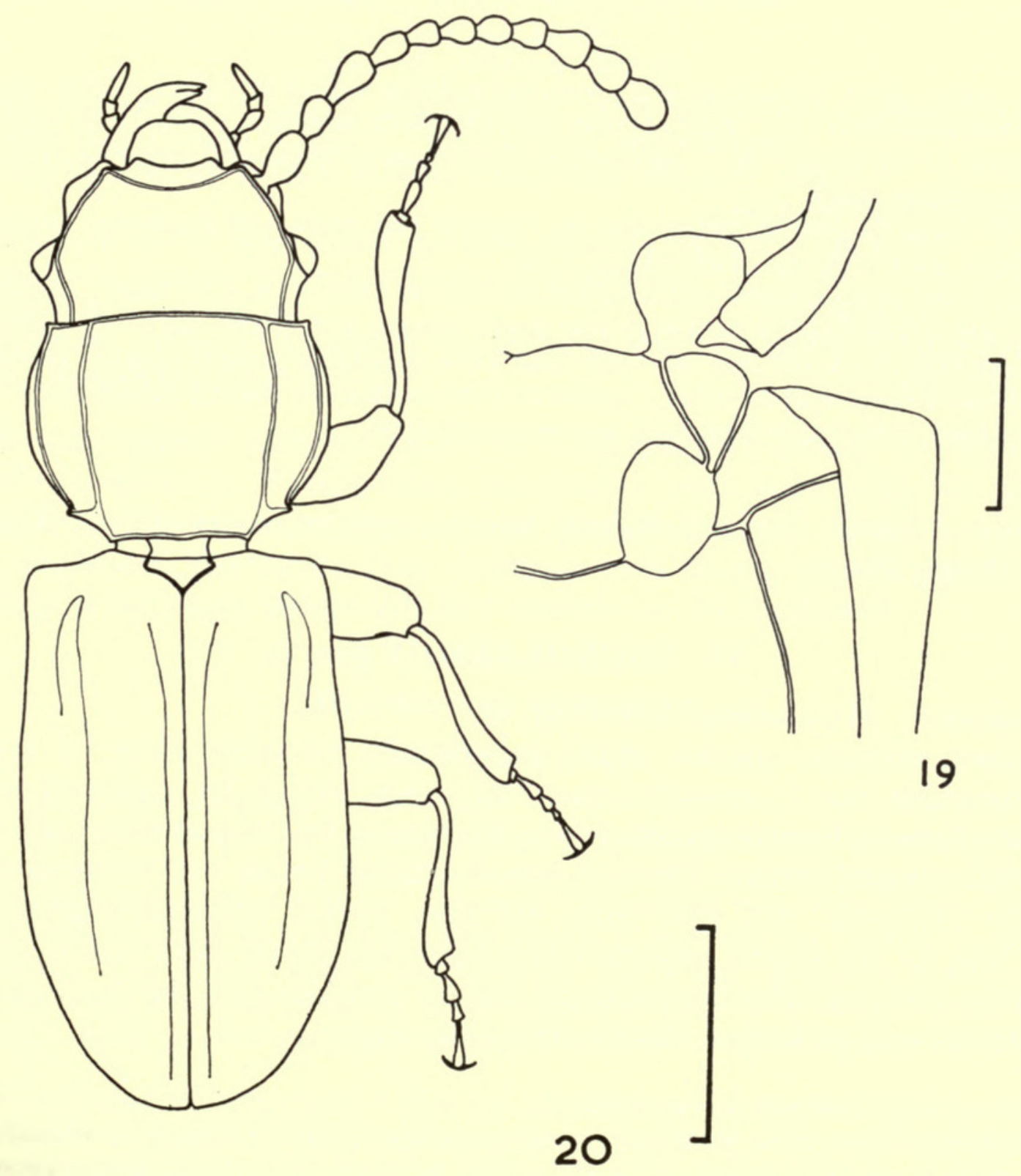

Figs. 19-20. (I9) Front and middle coxal cavities of Blubos matris ; (20) dorsal view of B. matris. Scale lines: Fig. $19=0.25 \mathrm{~mm}$.; Fig. $20=\mathrm{I} \mathrm{mm}$. 
Scutellum triangular, apex sharp; elytra with distinct, punctate striae, third cell developed apically ; not carinate laterally ; somewhat narrowed apically, rounded to apico-sutural angle, leaving part of last abdominal segment exposed dorsally.

Genae normal, gular sutures distinct; anterior coxal cavities broadly open behind, slightly transverse; hind margin of intercoxal prosternal process concave posteriorly; intercoxal process posteriorly deflected dorsally ; metepisternum not reaching mesocoxal cavity ; mesepimeron and metasternum meeting on a broad front (Text-fig. I9) ; metasternum as long as first and second abdominal sternites combined; intercoxal process of first visible abdominal sternite slightly rounded anteriorly ; abdomen narrowing towards apex ; first visible abdominal sternite twice as long as second, second to fourth equal to each other, the fifth slightly longer than fourth ; legs of normal length for the subfamily ; trochantero-femoral junctions of normal type ; tarsal formula $5^{-5-4}$ in the male; female unknown.

\section{Blubos matris sp. n.}

(Text-fig. 20)

About $4 \mathrm{~mm}$; head, pronotum and antennae reddish yellow in colour, elytra more yellow, the punctures somewhat red; each elytron with one dark brownish mark, both together giving the impression of the letter " M "; legs yellow with bases of tibiae and tarsi more red in colour ; apices of mandibles black.

Head with large punctures, separated by slightly less than one diameter, surface shining between them, each puncture with a short seta.

Pronotum with puncturation and setation on disc as that of disc of head; region between lateral line and lateral margin with very few, much smaller punctures, each with a seta.

Elytra with first, third and fifth intervals with a few punctures present basally, these punctures further separated than those of striae ; apices of elytra with a few slightly longer setae ; pygidium finely punctured, with fine reticulation between punctures.

Congo.

Holotype “ Kivu : contr. S. Kahuzi, km. 27, 2200 m., 28-iii-I953 P. Basilewsky ” (Mus. R. Congo Belge).

\section{MICROLAEMUS gen. $\mathrm{n}$.}

Type species : Microlaemus turneri sp. n.

This genus includes species which superficially resemble those of Hypocoprus Mots.; amongst the Laemophloeinae, the genus could be confused with some Cryptolestes but can be distinguished from that genus by the possession of a distinctly visible frontoclypeal suture, the transverse anterior coxae with their cavities open posteriorly (Text-fig. 2I), and with the fifth visible abdominal sternite about twice as long as the fourth whereas Cryptolestes has closed front coxal cavities, the coxae being globular, the frontoclypeal suture obsolete and the last visible abdominal sternite only as long as the fourth at the most.

I-2.5 mm. ; body moderately flattened.

Head somewhat triangular in shape; eyes moderate in size, situated in advance of base; antennae with scape and pedicel elongate, other segments transverse, distal three segments forming a loose club; epistome shallowly emarginate or truncate anteriorly; lateral line represented by raised ridge and closely approximated internal groove; frontoclypeal suture and median line represented by slight depressions in general surface of head. 
Pronotum slightly transverse or very occasionally very slightly longer than broad; anterior and posterior angles obtuse to rounded in shape; lateral line represented by raised ridge and a closely situated internal groove.

Scutellum triangular in shape ; elytra carinate laterally ; three cells developed, lateral margins of first and second indistinct; secondary intervals narrow.

Genae moderately well developed lateroventrally to trophi, gular sutures obsolete; anterior coxae transverse, with distinct lateral extensions, their cavities open posteriorly; intercoxal process of prosternum separating coxae to some extent, in the smallest species separation much less in proportion to general body structure than in more typical species of genus ; intercoxal process convexly rounded posteriorly; metepisternum just contributing to mesocoxal cavity, mesepimeron and mesepisternum contributing about equally; metasternum equal in length to first two visible abdominal sternites combined; intercoxal process of first visible abdominal sternites narrow and rounded anteriorly; first abdominal sternite $2 \cdot 25-2 \cdot 5$ times as long as second, second to fourth equal to each other, fifth somewhat longer, legs subequal; trochantero-femoral junctions of normal to elongate type; middle femora less dilated than either front or back; tarsal formula $5^{-5-5}$ in female, $5^{-5-4}$ in male.

\section{Key to African Species}

I. Body less than ${ }^{\circ} 5 \mathrm{~mm}$. in length ; frontoclypeal suture obsolescent 4 . slades $\mathrm{sp}$. n. (p. 199)

- Body more than $\mathrm{I} \cdot 5 \mathrm{~mm}$. in length ; frontoclypeal suture distinct . . . $\quad 2$

2. Body very dark brown to black in colour, palpi pale yellow in colour

3. palpalis (Waterhouse) (p. 198)

- Body brown in colour, palpi almost the same colour as the rest of the body . . 3

3. Head produced anterior to the insertions of the antennae and rather narrow across

the epistome (Text-fig. 22) . . . . . 2. ferrugineus $\mathrm{sp}$. $\mathrm{n}$. (p. I98)

- Head normally developed anterior to the antennal insertions and of normal width across the epistome (Text-fig. 23) . . . . . . I. turneri sp. n. (p. 197)

The following species, hitherto placed in Laemophloeus, belong to Microlaemus : M. sylvestris (Grouvelle), M. interceptus (Grouvelle), both from India, M. picipennis (Grouvelle) from Ceylon and $M$. sulcifrons (Grouvelle) from Réunion combb.n.; Lathropus brightensis Blackburn from Australia may belong to this genus although further study is necessary before this last opinion can be confirmed.

\section{Microlaemus turneri sp. n.}

(Text-figs. 23, 24)

$\mathrm{I} \cdot 75^{-2} \cdot \mathrm{O} \mathrm{mm}$. ; brown in colour ; pubescent.

Head I.5 times as wide as long; epistome rounded anteriorly ; frontoclypeal suture evenly concave; distance between anterior margin of eye and apex of epistome equal to that between anterior margin of eye and base of head; antennae just reaching base of pronotum; mandibles expanded laterally so that their posterolateral border is parallel with anterior border of the produced genae; disc of head evenly and shallowly punctured, punctures slightly larger in diameter than facet of eye, separated by distance equal to once to twice times their diameter, each with seta equal to two diameters in length; surface between punctures polygonally reticulate.

Pronotum very slightly transverse, widest at anterior quarter, slightly broader than head $(I \cdot I$ times), narrowed basally ; anterior and posterior angles slightly obtuse ; disc with punctures, setae and surface as on head.

Elytra twice as long as their combined width, broadest at their mid-point, there $\mathrm{I} \cdot \mathrm{I}$ times as broad as pronotum ; apices of the elytra separately rounded to the apico-sutural angle ; striate, setae as long as those of head and pronotum.

ENTOM. I2, 4 . 


\section{South Africa.}

Holotype male " Natal : Kloof I500 ft. Sept. I926 R. E. Turner " and 8 paratypes with same data; other paratypes: 6 "Zululand: Eshowe I-22.v.I926 R. E. Turner " ; I " Port St. John, Pondoland June I-II. I923 R. E. Turner "; 5 " Stn. No. 59 Deepwalls Forest. Knysna, I6-iii-I954, under bark of Yellow-wood, I725 ft. Cape Province J. Balfour Browne"; I "Stn. No. 59 Deepwalls Forest. Knysna, I7-iii-I954 small pool in glade, I725 ft. Cape Province J. Balfour Browne " (British Museum (Natural History)).

\section{Microlaemus ferrugineus $\mathrm{sp} . \mathrm{n}$.}

(Text-fig. 22)

Resembles $M$. turneri sp. n. except as follows: head very much more triangular, epistomal region quite narrow; distance between anterior margin of eye and epistome twice that of distance between anterior margin of eye and base of head ; frontoclypeal suture only slightly concave in shape.

Holotype “ Mauritius J. E. M. Brown B.M. I899-265” (British Museum (Natural History)).

\section{Microlaemus palpalis (Waterhouse) comb. n.}

Laemophloeus palpalis Waterhouse, 1876 .

Laemophloeus tenebrosus Grouvelle, I899, syn. n.

I. $8 \mathrm{~mm}$.; body reddish black in colour, maxillary palpi and tarsi yellow ; setae on head and pronotum white to yellow in colour.
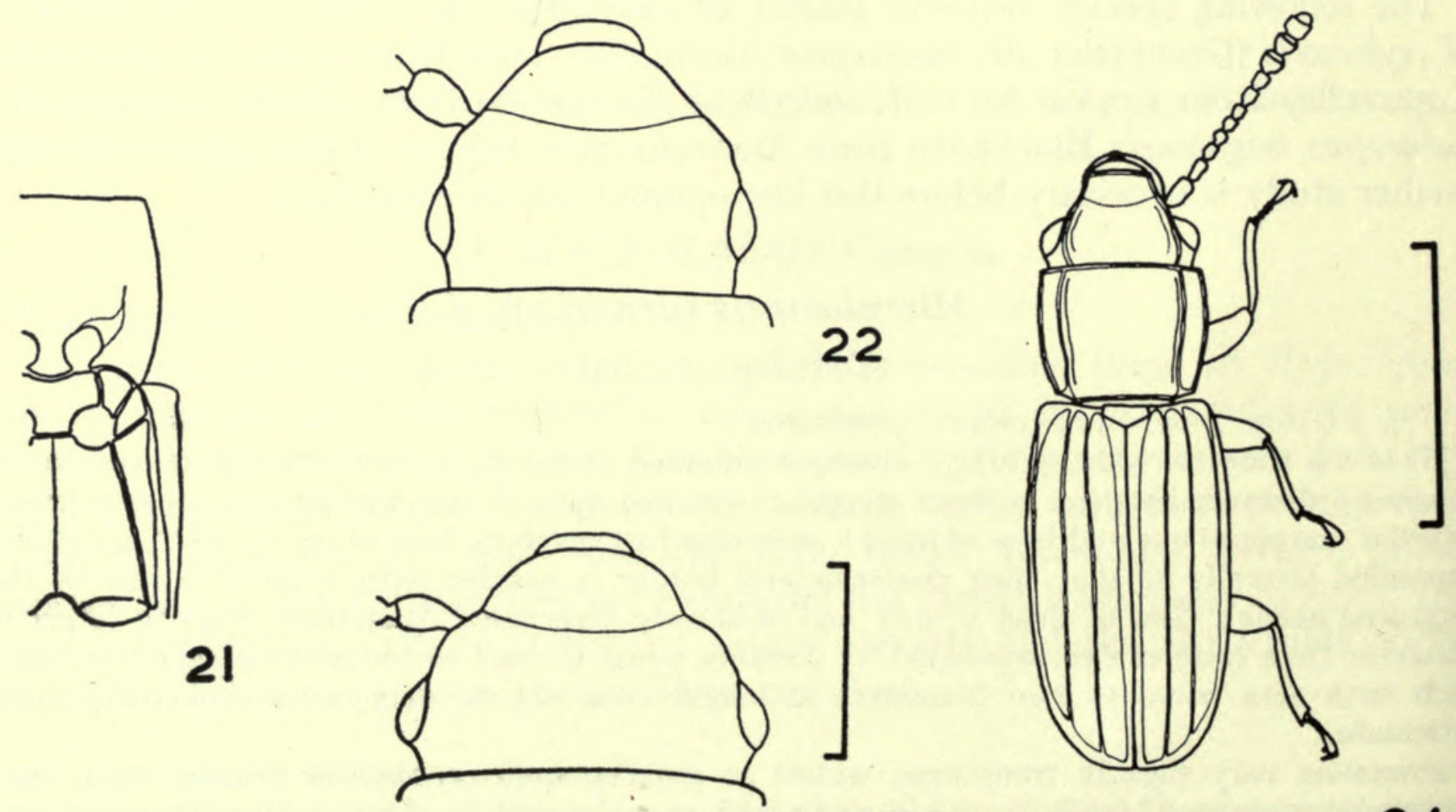

\section{3}

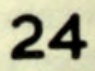

FIgs. 2I-24. (2I) Front and middle coxal cavities of Microlaemus slades; (22) head of $M$. ferrugineus and (23) of $M$. turneri; (24) dorsal view of $M$. turneri.

Scale lines: Figs. $2 \mathrm{I}-23=0.25 \mathrm{~mm}$. ; Fig. $24=\mathrm{I} \mathrm{mm}$. 
Head coarsely punctured, punctures equal in diameter to two eye facets, separated by less than half one diameter; punctures smaller on frons ; surface, including that of internal regions of punctures, reticulate.

Pronotum slightly longer than wide ; disc of pronotum punctured similarly to that of head, but punctures further separated ; surface reticulate ; lateral margin with eleven or twelve blunt tubercles; sublateral region with row of large, closely approximated punctures situated close to lateral line, their medial margins forming part of lateral line ; external to these punctures a second row of deep and smaller punctures alternating with first row but absent at base and apex.

In its body proportions this species is identical with the generic type.

Holotype “Rodriguez G. Gulliver 76-I5/Laemophloeus palpalis (Type) C. Waterh.” (British Museum (Natural History)). The holotype of L. tenebrosus Grouvelle, which bears the data "I. Bourbon [Mauritius]/Type [mss]/Laemophloeus tenebrosus Grouv " and a Paris museum type label, was found to be the same species as $M$. palpalis (Waterhouse).

\section{Microlaemus slades sp. $\mathbf{n}$.}

I•o mm.; yellowish brown in colour; pubescent, dull.

Head $\mathrm{I} \cdot 3$ times as wide as long; distance between anterior margin of eye and epistome $\mathbf{I} \cdot 5$ times that between anterior margin of eye and base of head; disc polygonally reticulate, apparently without punctures, covered with long setae, each seta being nearly as long as scape.

Pronotum $\mathrm{I} \cdot \mathrm{I}$ times as long as wide, at its widest $\mathrm{I} \cdot \mathrm{I}$ times as wide as head; anterior and posterior angles obtuse but rounded distally ; surface of disc reticulate and with setae as on head.

Elytra at their widest as wide as pronotum, twice as long as their combined width, pygidium sometimes partially exposed dorsally ; striate and with rows of setae, setae slightly shorter than those of head and pronotum.

Congo.

Holotype "Bas-Uele: Kotell I-2I.i.r925 Dr H. Schouteden" and 2 paratypes with the same data (Mus. R. Congo Belge); I paratype "Haut-Ovelle Env. de Madyu L. Burgeon I9I9” (Muséum National d’Histoire Naturelle, Paris).

\section{MAGNOLEPTUS gen. n.}

Type species: Magnoleptus pugnaceus sp. n.

This genus differs from the closely related Leptophloeus Casey in several ways, the most important being the considerably larger size of the adults, the tarsal formula of 5-5-4 in the males as against 5-5-5 in Leptophloeus, the arrangement of the intervals on the elytra, the detailed structure and arrangement of the mesocoxal cavities and the rather nebulous difference in the surface appearance. The genus resembles small Passandridae in its general appearance.

Body flattened cylindrical or cylindrical in shape ; $3-5 \mathrm{~mm}$.

Head as long as broad ; eyes small, situated one to two diameters in advance of base ; lateral line represented by raised ridge above and anterior to eyes, posterior to eyes the line obsolescent; frontoclypeal suture obsolete; epistome truncate anteriorly; antennae with pedicel shorter than scape or third segment, otherwise filiform or almost imperceptibly enlarged distally.

Pronotum longer than broad, narrowed basally, anterior angles rounded or obtuse, hind angles obtuse to acute, sometimes obsolescent; lateral line represented by a shallow groove closely approximated to an external raised ridge. 
Scutellum pentagonal; elytra more than 2.5 times as long as their combined width, sometimes more than three times; carinate laterally, carina formed by outer margin of third cell ; three cells present, secondary intervals narrower than cells.

Genae normal ; gular sutures distinct; anterior coxal cavities closed posteriorly, the coxae spherical, situated fairly close together; intercoxal process of the prosternum straight or slightly convex posteriorly ; metepisternum not contributing to the mesocoxal cavities (Text-fig. 25); posterior margin of mesosternum straight; median suture of the metasternum not reaching anterior margin of sclerite ; intercoxal process of first visible abdominal sternite narrow and rounded anteriorly, this sternite $\mathrm{I} \cdot 5$ times as long as second, second to fifth about equal to each other.

Legs subequal; trochantero-femoral junctions of normal type ; tarsal formula 5-5-5 in female, 5-5-4 in male.

\section{Key to SPEcies}

I. Head and pronotum black in colour, rugosely punctured, not shining; elytra parallel-sided and semi-truncate apically; hind angles of pronotum very obtuse (Text-fig. 27 )

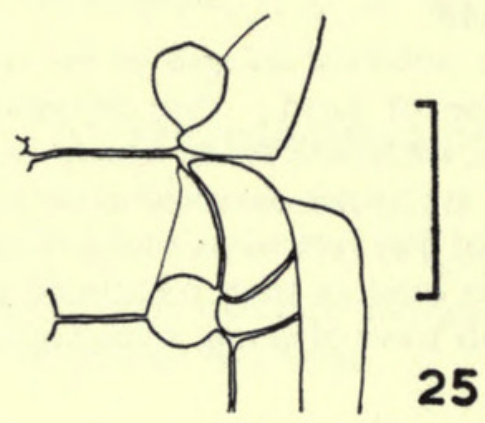

2. parallelicollis sp. n. (p. 201)
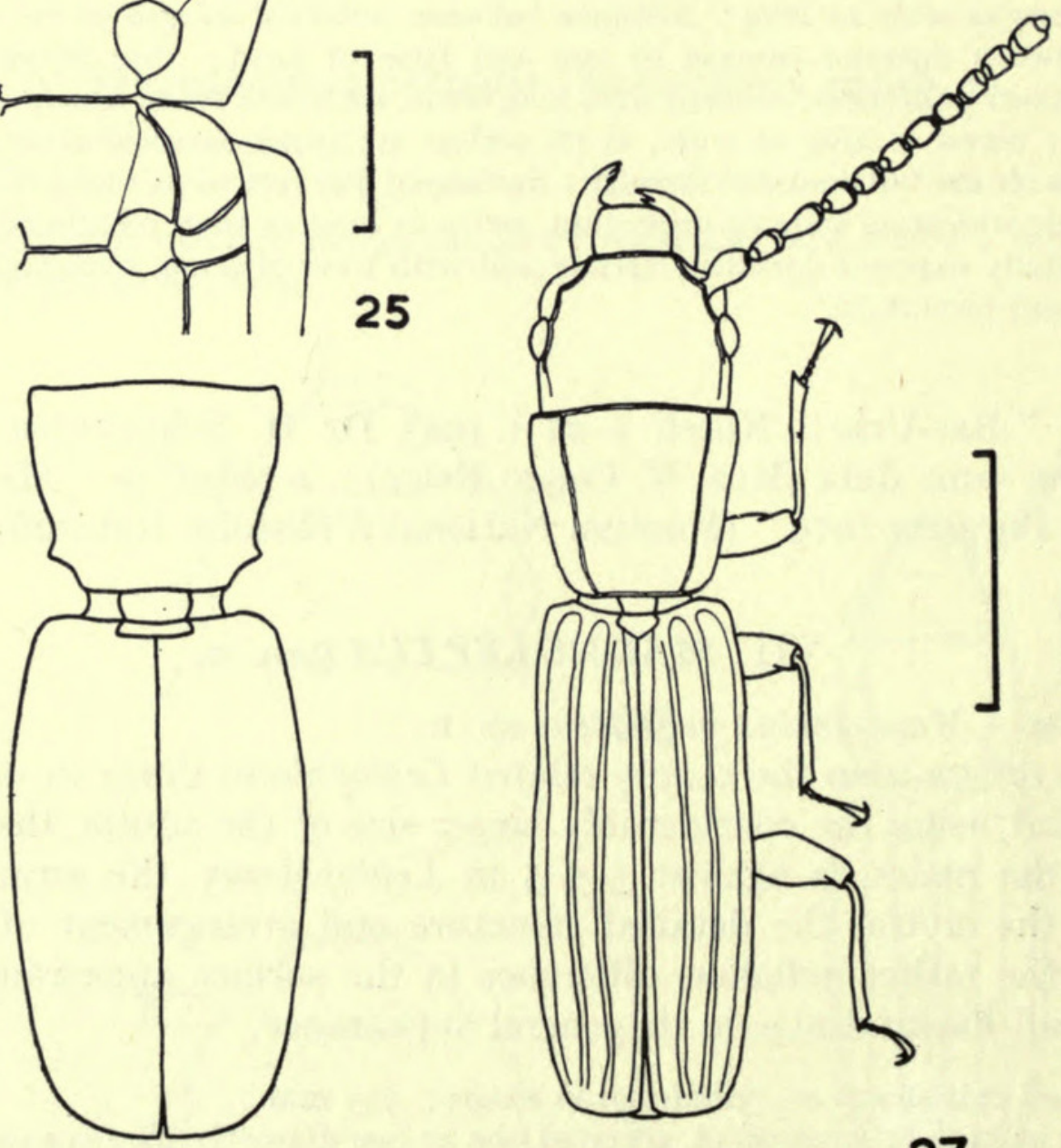

26

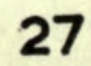

FIGs. 25-27. (25) Front and middle coxal cavities of Magnoleptus parallelicollis ; (26) dorsal view of thorax and elytra of $M$. pugnaceus; (27) dorsal view of $M$. parallelicollis.

Scale lines: Fig. $25=0 \cdot 25 \mathrm{~mm}$.; Figs. $26,27=\mathrm{Imm}$. 
- Head and pronotum blackish red, simply punctured, shining ; elytra diverging from their bases to just behind the mid-point and then narrowing somewhat; apices evenly rounded to the apico-sutural angle; hind angles of pronotum rectangular (Text-fig. 26)

. I. pugnaceus sp. n. (p. 20I)

\section{Magnoleptus pugnaceus sp. n.}

(Text-fig. 26)

$3 \cdot 0-5 \cdot 0 \mathrm{~mm}$.; body blackish red in colour except the tarsi which are less black.

Head as broad as or slightly broader across eyes than pronotum ; disc of head simply punctured, punctures somewhat elongate, separated by once to twice their diameter; surface between punctures micro-reticulate ; almost devoid of setae.

Pronotum somewhat broader than long; anterior angles rectangular and blunt, posterior angles very distinct and projecting ; puncturation and setation as on head.

Elytra about $2 \cdot 25$ times as long as their combined width, parallel-sided until mid-point and then narrowing somewhat apically, evenly rounded to apico-sutural angle; third cell obsolete basally but well developed apically.

Congo, Rhodesia, Angola.

Holotype male "N.W. Rhodesia Kashitu, N. of Broken Hill ii-I9I5 H. C. Dollman " and the allotype with the same data ; paratypes : I "Angola Io656.42 Marco de Canavezes (Cubal da Ganda), district de Benguela, piège lum., iii-56 Ed. Luna de Carvalho" (British Museum (Natural History)) ; I "Mulungu, I95 I P. C. Lefevre 69I Coll. R. Mayné Com. et Bois Congo r.237I". The following paratypes were collected by Dr. K. Schedl : I Yangambi I5.x.I952; 3 Mulungu 5.viii.I952; Io Yangambi I8.vii.I952; I Yangambi 2I.x.I952; 2 HembeBitale I8.vii.I952 ; 2 Ruanda Jhembe 29. vii. I952 (Mus. R. Congo Belge).

\section{Magnoleptus parallelicollis sp. $\mathrm{n}$.}

\section{(Text-fig. 27)}

3.0-3.5 mm.; head and pronotum black, trophi, antennae, legs and elytra brownish black; body quite cylindrical in section.

Head rugosely punctured, punctures elongate, intervals between punctures reticulate; setae quite short.

Pronotum slightly longer than broad; anterior angles obtuse and sharp, posterior angles very obtuse, almost obsolete; puncturation and setation similar to that on head.

Elytra three times as long as their combined width, parallel sided, each elytron subtruncate apically.

CONGO.

Holotype male "Recolté dans cellule de bambous/I.R.S.A.C.-Mus. Congo Kivu : Uvira, Hte Luvubu $265 \mathrm{~m} \mathrm{27-xii-1950}$ N. Leleup " and 2 paratypes with the same data (Mus. R. Congo Belge).

\section{LEPTOPHLOEUS Casey}

Leptophloeus Casey, r9i6.

Truncatophloeus Kessel, I92I, syn. n.

Type species: Laemophloeus angustulus Leconte (by original designation). 
This genus has been redescribed by Lefkovitch (1959b). Additions to that description follow : epistome rarely with tooth in mid-line or with two teeth; lateral line on head formed by raised ridge and closely approximated internal groove; elytra more or less parallel-sided; genae somewhat produced anteriorly; gular sutures obsolescent or obsolete; posterior border of intercoxal process of prosternum straight or very slightly concave posteriorly ; metepisternum not contributing to mesocoxal cavity; mesepimeron just reaching cavity, mesepisternum contributing to cavity but limited to a small region laterally ; median line of metasternum not reaching anterior third of sclerite; trochantero-femoral junctions of normal type; in two species $(L$. problematicus sp. n. and L. cornutus sp. n.) the hind tarsi of males four-segmented, otherwise 5-5-5.

Two species, Laemophloeus mobilis Grouvelle and L. insularis Grouvelle, are included in Kessel's (I92I) subgenus Truncatophloeus of Laemophloeus which was defined merely by " Der Clypeus ist vorn gerade abgestützt ". Examination of the type specimens of both species has shown that they have the generic characters of Leptophloeus. I now select Laemophloeus mobilis Grouvelle as type species of Truncatophloeus Kessel which thereby becomes a junior synonym of Leptophloeus Casey; both of these species are now transferred to Leptophloeus, comb. n.

The species of this genus fall into three groups which are not sufficiently distinct to define as subgenera. The clematidis group includes the darkly coloured, rather elongate species with a tendency to rugose sculpturing on the head and prothorax ; the alternans group include the brown (but occasionally black) species which are less elongate and which have simple puncturation without rugosity on the head and prothorax; the problematicus group is more distinct and includes those species having four-segmented hind tarsi in the males and with an unusual epistome. In other respects this last resembles the alternans group.

There remains the possibility that the problematicus species group does not properly belong to Leptophloeus; I am neither able to place them in any other genus nor find any difference in the structure of the adults which together with the curious epistomal structures and tarsal formula would justify the erection of a new genus to contain the species. They perhaps belong to a different subgenus from the other species here considered to belong to Leptophloeus but I would prefer to await the discovery of a third species, if one exists, before confirming or refuting this suggestion.

\section{Key to African Species}

I. Epistome produced into a tooth, horn or horns over the labrum

- Epistome not produced into a tooth or horns over the labrum but truncate or emarginate

2. Epistome with two lateral horns (Text-fig. 28); males with four-segmented hind tarsi . . . . . . . . . I6. problematicus sp. n. (p. 2 Io)

- Epistome with one more or less medial tooth ; males with four- or five-segmented

3. Punctures on head separated by a distance less than their diameter; head with medial raised ridge; males with four-segmented hind tarsi (Text-fig. 29)

I7. cornutus sp. n. (p. 210)

- Punctures on head separated by a distance greater than their diameter; head without medial raised ridge; males with five-segmented hind tarsi (Text-fig. 3o)

4. Epistome truncate or only very slightly emarginate anteriorly (Text-fig. 3I) 
- Epistome strongly emarginate anteriorly (Text-figs. 32, 33) . . . . . . $\quad$ Io

5. Body black and shining.

- Body brown and dull

6. Posterior angles of pronotum obtuse, clearly defined and somewhat projecting ; head simply punctured

I. ater sp. n. (p. 204)

- Posterior angles of pronotum obsolete; head longitudinally rugosely sculptured

7. Head with median line raised above general surface into a ridge

6. axillaris (Wollaston) (p. 206)

- Head, if with visible median line, the line is depressed

I4. bupleuri (Peyerimhof) (p. 209)

8. Elytra strongly carinate laterally, more than three times as long as their combined width . . . . . . . . 13. mobilis (Grouvelle) (p. 208)

- Elytra abruptly deflected laterally but not carinate, about 2.5 times as long as their combined width

9. Head and pronotum longitudinally rugosely sculptured; eyes situated about one diameter in advance of the thorax; elytra at shoulders as broad as the prothorax, subtruncate apically . . . . . . . . 7. parallelus sp. n. (p. 206)

- Head and pronotum simply punctured ; eyes almost contiguous with the prothorax, elytra at shoulders broader than the prothorax, broadly rounded apically

2. lucidus (Grouvelle) (p. 205)

Io. Pronotum $\mathrm{I} \cdot 5$ times as long as the breadth between the posterior angles

8. mucunae sp. n. (p. 206)

- Pronotum at most $\mathrm{I} \cdot 25$ times as long as broad between the posterior angles .
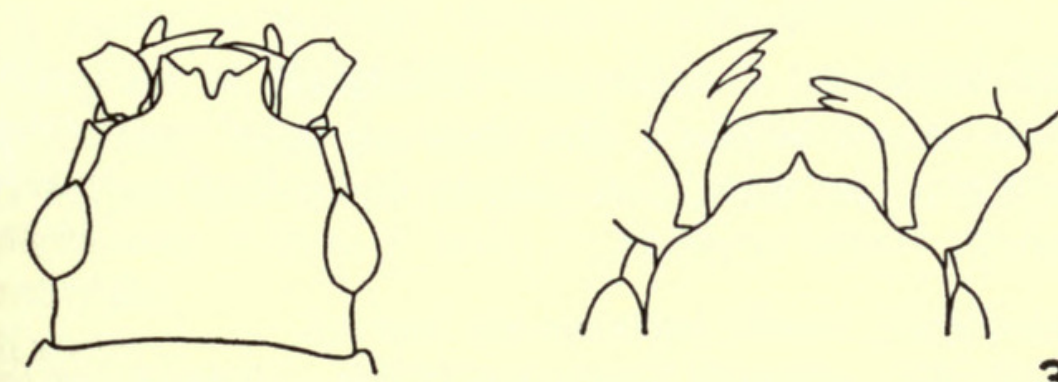

30
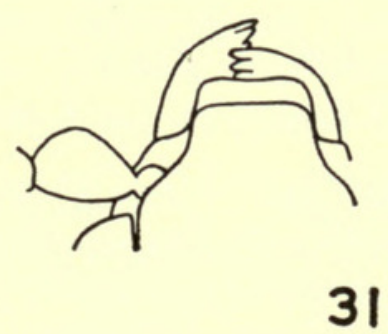

\section{8}

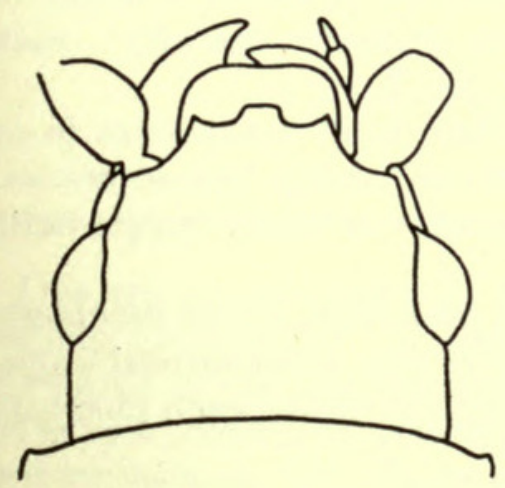

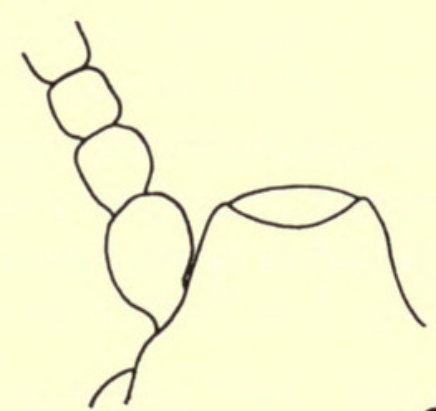

32

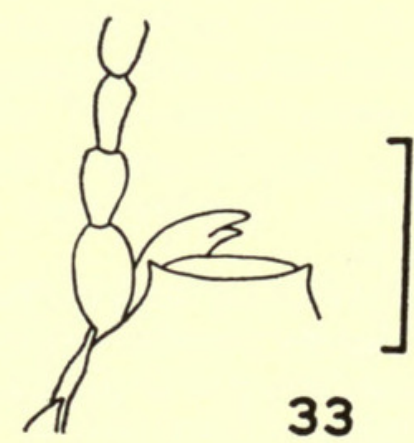

\section{9}

FIgs. 28-33. Heads of Leptophloeus; (28) L. problematicus; (29) L. cornutus ; (30) L. opaculus ; (3I) L. ater ; (32) L. janeti ; (33) L. punctatus.

Scale line $=0.25 \mathrm{~mm}$. 
II. Elytra about $2 \cdot 25$ times as long as their combined width

- Elytra at most about twice as long as their combined width

12. Pronotum at most as long as broad _ . . 5. stenoides (Wollaston) (p. 206)

- Pronotum longer than broad . . . . . . . . . . . . . $\quad . \quad$ I3

13. Body shining, reddish yellow in colour; head more or less smooth between the punctures . . . . . . . 9. cassavae sp. n. (p. 207) Body dull, brown in colour; head reticulate between the punctures

Io. linearis (Grouvelle) (p. 207)

I4. Third segment of antennae narrower than second; body dark brown in colour

II. punctatus sp. n. (p. 208)

- Third segment of antennae about as broad as second; body yellow to brown in colour

15. Head and pronotum smooth between the elongate punctures

I5. janeti (Grouvelle) (p. 209)

- Head and pronotum with longitudinal micro-sculpture between the more circular punctures .

I 2. capitus sp. n. (p. 208)

It has not been possible to include 3. L. anormus (Grouvelle) in this key since it has neither been recognized from the description nor has the type been located (infra, p. 205).

\section{The alternans Species Group (see p. 202)}

\section{Leptophloeus ater sp. n.}

(Text-fig. 3I)

This species is not unlike the European L. alternans (Erichson) in its general appearance but differs in that the colour is black, the eyes are more convex, the puncturation is coarser and the elytra are shorter in proportion to the rest of the body.

2.o mm.; head, pronotum and elytra black, trophi, antennae and legs red.

Head across eyes slightly broader than long ; epistome truncate anteriorly ; antennae reaching basal third of elytra, last three segments enlarged to form a loose club, last segment twice as long as wide ; disc of head with large punctures, about one and a half times to twice diameter of an eye facet, somewhat elongate in shape; punctures separated by a distance equal to once to twice their diameter basally, by twice to four times their diameter apically; each puncture with a very short seta, or apparently glabrous.

Pronotum longer than wide (I.I times); at its widest narrower than head across eyes (0.95 times); anterior angles obtuse and rounded; posterior angles obtuse, sharp and somewhat projecting; puncturation as on basal region of head, with very short setae or apparently glabrous.

Elytra twice as long as their combined width ; I I I times as broad as pronotum across shoulders, very slightly broader at mid-point; each elytron separately curved to the apico-sutural angle, just leaving tip of pygidium exposed dorsally in mid-line ; with punctured striae, each puncture subtending a short seta.

Congo.

Holotype and I paratype "Mulungu, I95I P. C. Lefevre P. C. L. 642 "; other paratypes: I "Mulungu 8-viii-I952 R. Mayné. R.M. 592A"; 3 "Mulungu 5-viii-I952 Dr. Schedl Nr. 267” (Mus. R. Congo Belge). 


\section{Leptophloeus lucidus (Grouvelle) comb. n.}

Laemophloeus lucidus Grouvelle, I908.

This species resembles $L$. ater sp. n. in almost all details and differs primarily from that species in the colour of the main part of the body which is brown and not black. Since Grouvelle's original description is very detailed, no further redescription will be given here.

EAST Africa, Ethiopia.

Holotype "Af. or All. Amani/Eichelbaum/Type [mss]/3h/Laemophloeus lucidus Grouv ty" and a Paris museum type label.

In addition to the holotype described from Dar-es-Salaam, the following specimens have been examined : I "Abyssinia : Djem-Djem Forest nearly 9,000 ft. I-X-I925 Dr. H. Scott ” ; I "Abyssinia/Schimper 430-50".

\section{Leptophloeus anormus (Grouvelle) comb. $\mathrm{n}$.}

Laemophloeus anormus Grouvelle, I923.

Although the type specimen of this species has not been located in either the Grouvelle or the Alluaud collections, the original description presents sufficient information to establish that the species properly belongs to Leptophloeus. Grouvelle wrote that the species is related to L. janeti (Grouv.) and L. axillaris (Woll.), being distinguished from the former by the truncate epistome and from the latter by the more slender antennae, the more elongate body and an emargination at the outside of the base of the prothorax. I have not been able to recognize specimens of a species resembling $L$. janeti and $L$. axillaris, but differing from them as given and agreeing with the rest of the description of $L$. anormus. In my key to species of Leptophloeus (supra, p. 202), L. anormus would probably be identified as L. lucidus (Grouvelle).

KENYA.

According to the original description, the species was found "Rivière Amboni dans la zone des prairies inferieures du mont Kenya, alt. 2,000 m.” by Alluaud.

\section{Leptophloeus opaculus (Grouvelle) comb. n.}

$$
\text { (Text-fig. 30) }
$$

Laemophloeus opaculus Grouvelle, 1908.

This species resembles $L$. lucidus fairly closely but differs in the epistome having a pointed tooth in the mid-line. In other respects, this species resembles the species of the alternans group. The figure of the head (Text-fig. 30) will enable accurate recognition of the species. Since only the type is known, there remains the possibility that this specimen is an abnormal individual of another species. The shape of the prothorax, however, with its projecting, slightly acute hind angles is unlike that of any other African species of the genus.

EAST AFrica.

Holotype "Afr. or. All. Amani Eichebaum [sic] Type/Laemophloeus opaculus Grouv. ty." 


\section{Leptophloeus stenoides (Wollaston) comb. n.}

Laemophloeus stenoides Wollaston, 1854 .

Resembles L. alternans (Erichson) very closely but differs in the greater emargination of the epistome and in having the surface of the head and of the pronotum polygonally reticulate upon a moderately rugose sculpturing.

The surface is so distinct in this species as to distinguish it completely from other Leptophloeus occurring in Africa.

\section{MADEIRA.}

HoLotype, the only specimen seen, is in the Wollaston collection (British Museum (Natural History)). It has a British Museum type label and " Laemophloeus stenoides, type Woll " in a handwriting I do not recognize but which may be that of Arrow.

\section{The clematidis Species Group (see p. 202)}

\section{Leptophloeus axillaris (Wollaston) comb. n.}

\section{Laemophloeus axillaris Wollaston, 1854 .}

This species resembles $L$. clematidis in its general appearance but is reddish black rather than brown in colour, shining rather than dull; the humeral region of the elytra is slightly redder than the remainder.

Eyes situated very far in advance of base of head, very small; head large in proportion to remainder of body, as long as broad ; surface rugosely punctured, the sculpture tending to run into longitudinal ridges; very slightly pubescent; median line slightly impressed.

Pronotum as long as broad, slightly narrowed basally; anterior angles obtuse, posterior so obtuse and rounded as to be obsolete; surface punctured as on head.

\section{MADEIRA.}

HoLotype a single specimen in the Wollaston collection (British Museum (Natural History)). It has a British Museum type label and "Laemophloeus axillaris, type Woll " in a handwriting I do not recognize but which may be that of Arrow. I have not recognized further specimens of this species.

\section{Leptophloeus parallelus sp. n.}

Although belonging to the clematidis group of the genus, this species is most likely to be confused with L. lucidus (Grouvelle); the distinguishing characters presented in the key to species should prove adequate to prevent any confusion between these two species. However, $L$. parallelus is very closely related to L. axillaris (Wollaston) from which it differs in colour and distribution; L. axillaris is reddish black in colour and occurs in Madeira whereas L. parallelus is brown (albeit dark) and occurs in the Congo.

Congo.

Holotype and I paratype "Luki 5-vi-I952 Dr. Schedl s.I36" (Mus. R. Congo Belge).

\section{Leptophloeus mucunae sp. n.}

This species can be distinguished from its nearest relatives by the characters outlined in the key to species.

$\mathrm{I} \cdot 5^{-2} \cdot \mathrm{O} \mathrm{mm}$; ; body brownish red in colour, moderately shining. 
Head transverse, $\mathrm{I} \cdot 6$ times as wide as long ; epistome concave anteriorly; antennae rather short, hardly reaching base of pronotum, last three segments enlarged forming a loose club, last segment at most $\mathrm{I} \cdot 5$ times as long as broad ; surface of disc punctured, punctures twice as large in diameter as facet of an eye, separated by a distance equal to less than one diameter ; each puncture subtending a small seta ; surface between punctures somewhat irregular (not reticulate but tending towards micro-rugosity) and shining.

Pronotum considerably narrowed basally, maximum width slightly broader than head, I.5 times as long along mid-line as broad between hind angles; anterior angles obtuse, posterior obtuse and somewhat projecting; surface of pronotum as coarsely and closely punctured as on head.

Elytra $2 \cdot 3$ times as long as their combined width, at shoulders narrower than pronotum at broadest; together evenly rounded apically, not leaving last abdominal segment exposed dorsally; the three cells developed, secondary intervals being very narrow ; with punctured striae.

\section{Uganda, Congo.}

Holotype and 3 paratypes: "Velvet bean seed/Uganda, Kampala -xi-I932 H. Hargreaves " (British Museum (Natural History)) ; I " Miss. H. de Saeger 3787 " (see Appendix) (Mus. R. Congo Belge).

\section{Leptophloeus cassavae sp. n.}

This is a comparatively small species of the genus ranging from $\mathrm{I} \cdot 6-\mathrm{I} \cdot 9 \mathrm{~mm}$. It resembles L. alternans (Erichson) and L. lucidus (Grouvelle) in many ways but differs in that the body is somewhat more slender than in those species, thus resulting in, for instance, the pronotum being slightly longer than broad; the epistome is emarginate anteriorly and not truncate ; the puncturation of the head is coarser than the facets of the eyes and not finer; the antennae resemble those of $L$. alternans rather than those of $L$. lucidus although the difference between the antennae is very slight ; in other respects the three species appear to be identical externally.

Holotype and 3 paratypes "Sierra Leone. Njala Ex Cassava branch ix-I935 E. Hargreaves " (British Museum (Natural History)).

\section{Io. Leptophloeus linearis (Grouvelle) comb. $\mathbf{n}$.}

\section{Laemophloeus linearis Grouvelle, 1908.}

In the key to African Laemophloeinae presented by Grouvelle (I908), this species and $L$. punctatus sp. n. would be identified as L. hypobori (Perris). Nevertheless, the differences between them and L. hypobori are considerable.

The following differences between $L$. linearis and $L$. clematidis will serve as a description of the species: in $L$. linearis segments of antennae elongate, eyes moderately convex, pronotum broadest just behind anterior angles, elytra as broad across shoulders as pronotum at widest, general surface less pubescent than in L. clematidis where antennal segments transverse, eyes hardly convex, pronotum broadest at anterior third and elytra broader across shoulders than pronotum at widest.

Congo, Ethiopia.

Holotype "Abyssinie/Type/L. linearis A. Grouv." Other specimens seen include 7 "Ituri: Djugu ii-I935. H. J. Bredo"; I " Kivu: NGweshe v-I938 J. Ghesquière" ; I "Kivu: Terr. Kabare Nyakasiba, I80o m (vestige forêt) vi-I95I N. Leleup " ; I “ N. Kivu : Loashi viii-I937 J. Ghesquière " ; I " Uganda : 
Bugiri, I400 m savane boisée 5/8-viii-I957 P. Basilewsky et N. Leleup " (Mus. R. Congo Belge).

\section{Leptophloeus punctatus sp. $\mathrm{n}$.}

(Text-fig. 33)

This species resembles the preceding, differing only in the following details : in general shape body less flattened, almost cylindrical ; elytra about twice as long as their combined width, punctures on head and pronotum simple, surface without any rugosity.

\section{Congo.}

Holotype " Galerie forestière de la Kisanga dans humus. Environ d'Elisabethville. Septembre I948 N. Leleup"; paratypes: I "Recolté dans l'humus (forêt de Hagenia)/Kivu: Terr Kabare, contrel S.E. Kahuzi, 2080 m I3-viii-I95I N. Leleup " ; 2 "Sur Lobelia/Kiball-Ituri : Mont Bughera 2200 m xi- I953 R. R. P. P. Bergmans-Celis"; I "Dans inflorescences de Lobelia/N. Kivu: env. Lubero, 2300 m 6-viii-I953 R. P. M. J. Celis \& Coll.” ; I “ Kwesi \& Kilo Io/I9-iv-I9Ir Dr. Bayer " ; I "Ituri La Moto ; Madyu L. Burgeon " ; I " Miss. H. De Saeger 3787" ; I "Miss. H. de Saeger I724" (see Appendix) (Mus. R. Congo Belge).

\section{I2. Leptophloeus capitus sp. n.}

This species resembles $L$. punctatus sp. $\mathrm{n}$. in most respects but differs as follows : antennal segments at most as broad as long, median line on the head visible although not deep, punctures on the head separated by one or two diameters whereas L. punctatus has the antennal segments longer than broad, the median line of the head obsolete and distance between punctures on head equal to half to once their diameter.

South AFrica.

Holotype “Port St. John, Pondoland Sept. I923/S. Africa R. E. Turner" and I paratype with the same data (British Museum (Natural History)).

\section{Leptophloeus mobilis (Grouvelle) comb. n.}

Laemophloeus mobilis Grouvelle, 1908.

Head as broad as long, eyes somewhat projecting ; antennae reaching basal quarter of elytra, terminal three segments at most $\mathrm{I} \cdot 5$ times as long as broad; surface of disc with elongate punctures separated by narrow ridges, almost rugose ; with fine, narrow longitudinal reticulation between the punctures.

Pronotum just narrower than head across eyes, slightly longer than broad, weakly narrowed basally; lateral line represented by ridge and internal groove, the latter deeper in mid-region than anteriorly or posteriorly ; anterior angles obtuse and blunt, posterior angles obtuse and rounded; surface as on head.

Elytra at shoulders slightly broader than pronotum at its widest, broadening until basal eighth and then parallel-sided until apical third, then evenly rounded together ; 2.5 times as long as their combined width ; the three cells developed, secondary intervals being half width of cells.

EAST AFrica, Congo.

The single male in the Grouvelle collection is selected as lectotype and is labelled "Zanzib./Type/Laemophloeus mobilis Grouv. ty." There is another syntype in 
the Deutsches Entomologisches Institut. I have seen I other specimen " Congo Belge Hembe-Bitale I9-viii-I952 Dr. Schedl ” (Mus. R. Congo Belge).

\section{I4. Leptophloeus bupleuri (Peyerimhof) emend. comb. $\mathrm{n}$.}

Laemophloeus bupleri Peyerimhof, 1948.

This species was called bupleri in the original description but was referred to as bupleuri elsewhere in the paper and was named after Bupleurum spinosum L. The spelling bupleri is quite clearly an error and is here corrected.

L. bupleuri belongs to the clematidis group of Leptophloeus but is unique in having the median line of the head raised into a strong ridge. The head is otherwise rugose, slightly longer than broad ; the antennae do not reach the base of the pronotum ; the front angles of the pronotum are obtuse, the hind angles so obtuse as to be obsolescent ; pronotum just broader than the head, about $\mathrm{I} \cdot 25$ times as long as broad; elytra at shoulders slightly broader than the pronotum, about $2 \cdot 25$ times as long as their combined width, leaving the tip of the abdomen exposed dorsally.

\section{Algeria.}

There are five syntypes, two mounted on one card with the data " Agouni Boussouil Djuidjusa vi-vii-I947/Bupleurum spinosum/Laemophloeus Bupleuri Peyerh. TYPES I-2" ; two mounted on separate cards but on one pin have data as above but "TYPES 3-4"; the fifth is mounted alone and has the same data except for "TyPe 5". The specimen implied by TyPE I is selected as lectotype.

\section{Leptophloeus janeti (Grouvelle)}

(Text-fig. 32)

Laemophloeus janeti Grouvelle, 1899 .

L. janeti resembles L. capitus sp. n. very closely, both these species differing from L. punctatus sp. n. in being yellow rather than chestnut in colour and in the ratio between the length of the elytra to the length of the head and pronotum combined being $\mathrm{I}_{4} 4$ or less in contrast with the figure of $\mathrm{I} \cdot 6$ in $L$. punctatus. In addition to the characters given in the key, L. janeti differs from L. capitus in having the secondary intervals and to a lesser extent the raised regions between the strial punctures yellow in colour whereas the elytra of L. capitus are a uniform reddish yellow.

Two specimens in the Grouvelle collection, Paris, bear printed data labels as follows : "Museum Paris/Congo/Libreville/H. Lecomte 56-97". One of these two specimens bears the word "type" in Grouvelle's later handwriting in his usual purple ink ; the other has a ms. label " Laemophloeus Janeti Grouv." in Grouvelle's early handwriting in black ink. In his original description Grouvelle gave as locality the following information: "Congo: Libreville. Museum de Paris et collection A. Grouvelle.-Espèce decouverte a Paris dans une noix de Cacao, contentant un nid de Monomorium floricola, envoyée au Museum par M. Lecomte ". Consequently, I feel confident that the two specimens indicated above are syntypes. I select the specimen bearing the name " Laemophloeus Janeti Grouv." as lectotype. The other specimen is rather smaller than is usual for the species. 
It is interesting to note that this species, when correctly recognized in stored products, has always been associated with cocoa and coffee beans.

I have seen specimens from throughout the Congo and from Uganda and Ghana.

\section{The problematicus Species Group (see p. 202)}

Two species belong here, Leptophloeus problematicus sp. n. and L. cornutus sp. n., which appear to be unique in the genus in possessing four-segmented tarsi in the hind legs of the male.

\section{Leptophloeus problematicus sp. $\mathrm{n}$.}

(Text-fig. 28)

The following differences from $L$. janeti (Grouvelle) will serve as a description of this very distinct species : colour brown rather than red, puncturation coarse, close ; epistome produced into a plate and two horns over labrum.

Congo.

Holotype male and 3 paratypes: "Yangambi I8-vii-I952 Dr. Schedl Nr. 468”,

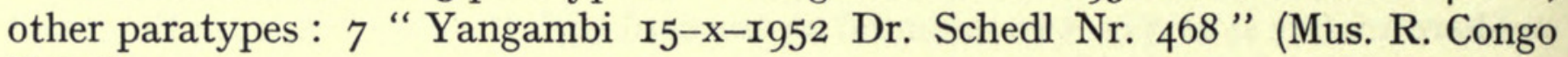
Belge).

\section{I7. Leptophloeus cornutus sp. n.}

(Text-fig. 29)

This species resembles $L$. problematicus sp. $\mathrm{n}$. very closely, differing primarily in the structure of its epistome which in $L$. cornutus has a short sharp median horn contrasting with the plate and two horns to be found in L. problematicus.

Congo.

HoLotype and I paratype "Yangambi I8-vii-I952 Dr. Schedl Nr. 468 " ; other paratypes : 4 "Yangambi I5-X-I952 Dr. Schedl Nr. 468" ; I "Luki I2.vi. I952 Dr. Schedl s.I64a” ; 2 "Luki 5-vi-I952 Dr. Schedl s.I36”"; I " Luki II-vi-I952 Dr. Schedl s.I95" ; I " Yangambi 9-ix-I952 Dr. Schedl Nr. 802 " ; I " Sankuru : Lodja Io-v-I929 J. Ghesquière” (Mus. R. Congo Belge).

\section{NARTHECIUS Leconte}

Narthecius Leconte, I86r.

Paraphloeus Sharp, I899 syn. n.

Type species: Narthecius grandiceps Leconte (by monotypy).

Body cylindrical.

Head longer than broad; epistome acuminate apically, epistome symmetrically or asymmetrically produced over labrum into narrow horn ; head longitudinally shallowly grooved on each side of horn between horn and insertion of antennae, with a raised ridge on outside in some species ; eyes situated well in advance of base, flush with the surface of the head or hardly convex, with moderately large facets ; antennae inserted just below lateral carinae at base of acumination, with terminal three segments broader than remainder, with scape in some species an irregular isoseles triangle in shape, pedicel being inserted at external apical angle, in other 
species scape almost spherical ; frontoclypeal suture obsolete ; lateral carinae represented by raised ridge ; an impressed median line usually present ; gular sutures distinct and well separated; genae moderately produced but negligibly so when compared with Passandridae, Prostomis or Passandrophloeus ; labrum transverse, shallowly emarginate anteriorly.

Pronotum longer than broad, as long as or shorter than head; suture between the pronotum and the pleural sclerites not lateral but lateroventral, sometimes partially visible from above ; anterior angles rounded, posterior obtuse and well defined; lateral line represented by raised ridge and internal groove.

Scutellum more or less semicircular ; elytra parallel-sided, about twice as long as their combined width, about $\mathrm{I} \cdot 5$ times as long as pronotum ; the three cells developed, secondary intervals being as broad as cells or narrower.

Anterior coxal cavities open posteriorly, situated close together ; intercoxal prosternal process convexly rounded posteriorly ; mesosternum very small and consisting of a narrow strut posteriorly between middle coxae; meso- and metepisterna not contributing to mesocoxal cavities, these being formed by meso- and metasterna with mesepimeron ; metasternum equal in length to first four visible abdominal sternites combined; first visible abdominal sternite $\mathrm{I} \cdot 5$ times as long as second in mid-line, its intercoxal process narrow, sharply rounded anteriorly ; second to fourth sternites about equal to each other, fifth longer but not as long as first.

Legs rather short, almost warranting description as brachypodous; trochantero-femoral junctions of normal type, femora strongly dilated; tibiae sinuate ; tarsal formula $5-5-5$ in both sexes; in some (American) species the paired apical spines on tibia asymmetrically developed on the front legs, symmetrically on the others.

Paraphloeus Sharp was erected to contain two species from Central America; the type species, P. crassiceps Sharp, quite clearly is a Narthecius, probably conspecific with $N$. grandiceps and is now placed in that genus comb. n. The other species, $P$. longicollis Sharp, belongs to a different group within the Laemophloeinae meriting generic status. In contrast with Sharp's opinion, Paraphloeus has five tarsal segments in each leg and not four (or three, as he claimed to be present in the front legs). The basal segment is almost entirely withdrawn (in dried specimens, at least) into the tibia and is hardly, if at all, shorter than the second; what little protrudes from the shaft is normally hidden by the spurs, spines, knobs and setae with which the tibia is ornamented in this region.

I have neither been able to see the type of nor recognize $N$. haroldi Reitter, described from Madagascar. Its description suggests that it is not Narthecius but is more related to the Oriental $N$. suturalis Grouvelle which, as indicated below, is considered to belong to a genus distinct from Narthecius. N. haroldi would appear to be distinguished from the species described below as follows :

Epistome asymmetrically acuminate anteriorly Epistome weakly curved anteriorly
N. schedli sp. n. (p. 2I I)

N. haroldi Reitter

\title{
Narthecius schedli sp. n.
}

\author{
(Text-figs. 34, 35)
}

About $\mathrm{I} \cdot 8 \mathrm{~mm}$.; body reddish brown in colour, elytra less intensely so.

Eyes slightly convex, situated $\mathrm{I} \cdot 5$ times their diameter in advance of base; surface of head with slightly longitudinally elongate punctures, not very much smaller to half the diameter of facets of eyes, separated by about one diameter; surface between punctures minutely polygonally reticulate; apparently without setae. 
Pronotum about $\mathrm{I} \cdot 25$ times as long as broad, slightly longer than head; surface as on head ; elytra about 2.5 times as long as their combined width, parallel-sided until apical third, there gently turning inwards and evenly rounded to apico-sutural angles ; strial punctures very minute, each with a thin short seta.

\section{Congo.}

Holotype "Congo Belge Yangambi 25-ix-I952 Dr. K. Schedl Nr. 96r " ; paratypes collected in same locality but on different dates: I, 24-vi-I952 (S.215); I, 30-vi-I952 (S.265) ; 2, 24-ix-I952 (R.944) ; 2, 3I-X-I952 (R.949) (Mus. R. Congo Belge).

It is rather difficult to know with which species to compare $N$. schedli. The American members of the genus are very different in their body form and can easily be distinguished as a group by the following key. Those from the Oriental region which are more closely related are as yet undescribed $(N$. suturalis Grouvelle is probably generically distinct). The following key will indicate the most obvious differences :

I. Eyes situated three diameters in advance of the base, hardly, if at all, convex; scape large and irregularly triangular in shape ; grooves on each side of the frontal horn ridged externally; epistomal horn centrally placed (Text-fig. 36)

American NARTHECIUS

- Eyes situated I.5 diameters in advance of the base, slightly convex; scape globular ; grooves on each side of the frontal horn not ridged externally but merging with the general surface of the head; epistomal horn asymmetrically placed .

2. Epistomal horn with a narrow base, the head otherwise hardly produced anteriorly to the antennal insertions (Text-fig. 37) .

Oriental NARTHECIUS

- Epistomal horn with a broad base, the head being clearly produced anteriorly to the antennal insertions (Text-fig. 35)

N. schedli sp. n.
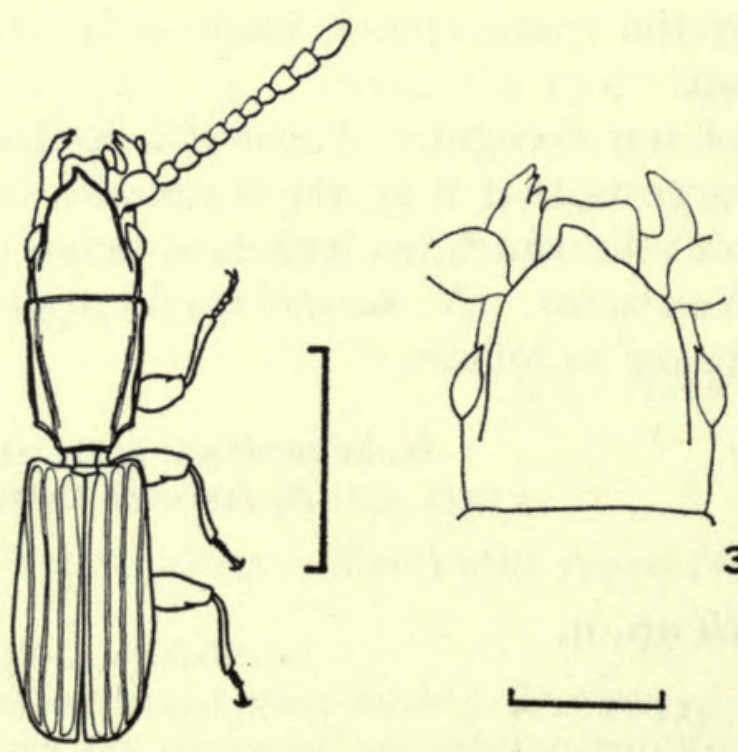

\section{4}

FIgs. 34-37. (34) Dorsal view of Narthecius schedli; (35) head of N. schedli; (36) of American Narthecius and (37) of Oriental Narthecius.

Scale lines : Fig. $34=\mathrm{I} \mathrm{mm}$. ; Figs. $35-37=0.25 \mathrm{~mm}$. 


\section{PASSANDROPHLOEUS Kessel}

Passandrophloeus Kessel, I921.

\section{Type species : Laemophloeus spinosus Grouvelle (present designation).}

This genus could easily be confused with Leptophloeus but can be easily recognized by the ventral structure of the head, the anterior coxal cavities (Text-fig. 38), the shape of the intercoxal process of the first abdominal sternite in addition to the characters given in the key to genera.

Of the seven species listed by Kessel in Passandrophloeus, I select spinosus Grouvelle as the type species. This species is very similar to the single African species redescribed below and may prove to be conspecific.

Body moderately flattened ; $2-4 \mathrm{~mm}$.

Head in male triangular in general shape (Text-fig. 40); eyes situated in advance of base, a distinct ridge present behind eye ; width of head across eyes more than that of pronotum at widest; head in female less obviously triangular in shape (Text-fig. 4I) ; eyes almost in contact with the base, no distinct ridge behind eye ; width across eyes rarely as much as that of pronotum ; in both sexes, frontoclypeal suture and median line obsolete; epistome truncate anteriorly ; antennae with scape, pedicel and terminal three segments distinctly larger than other six segments ; two lateral lines on each side, inner one depressed, outer one ridged and anteriorly forming margin to epistome; external region of mandibles in male produced ventrally and laterally, this production often reaching to beneath produced genae; in female mandibles not produced externally lateroventrally.

Pronotum with indistinct obtuse anterior angles and with distinct acute posterior angles; two lateral lines on each side, inner consisting of internal shallow groove and external ridge, outer essentially a groove between ridge of inner line and a secondary ridge ; this outer groove may consist of a row of largish punctures behind mid-line ; the outer ridge is recurved externally in front, then runs posteriorly close to lateral margin.

Scutellum triangular; elytra carinate laterally, the three cells developed, the carinal fold being closely approximated to outer margin of third ; apices of elytra usually truncate in male, with external apical angles turned outwards; apices sometimes describable as truncate in females but usually evenly rounded to suture.

Genae normal in female, in male this region developed ventrally and slightly laterally into a heavy jowl on each side (Text-fig. 39) ; gular sutures distinct; anterior coxal cavities closed behind, each with a lateral extension ; intercoxal process of prosternum concave posteriorly; coxae well separated; metepimera not contributing to mesocoxal cavities; intercoxal process of first abdominal sternite almost straight anteriorly ; metasternum about as long as first three abdominal sternites ; first abdominal sternite twice as long as second, second to fourth about equal in length to each other, fifth somewhat longer; trochantero-femoral junctions of the normal type ; tarsal formula $5^{-5-5}$ in female, $5^{-5-4}$ in male.

\section{Passandrophloeus glabriculus (Grouvelle) comb. n.}

$$
\text { (Text-figs. 39-4I) }
$$

Laemophloeus glabriculus Grouvelle, I897.

Laemophloeus divergens Grouvelle, 1908 syn. $\mathbf{n}$.

This species is fairly widespread in the Oriental and African regions and appears to be associated with trees of the Dipterocarpaceae.

About $2 \mathrm{~mm}$.; head, antennae, pronotum and legs yellowish red in colour, elytra essentially the same colour but since they are transparent or almost so, they appear to be a dirty white over the metathoracic wings.

ENTOM. 12, 4 . 

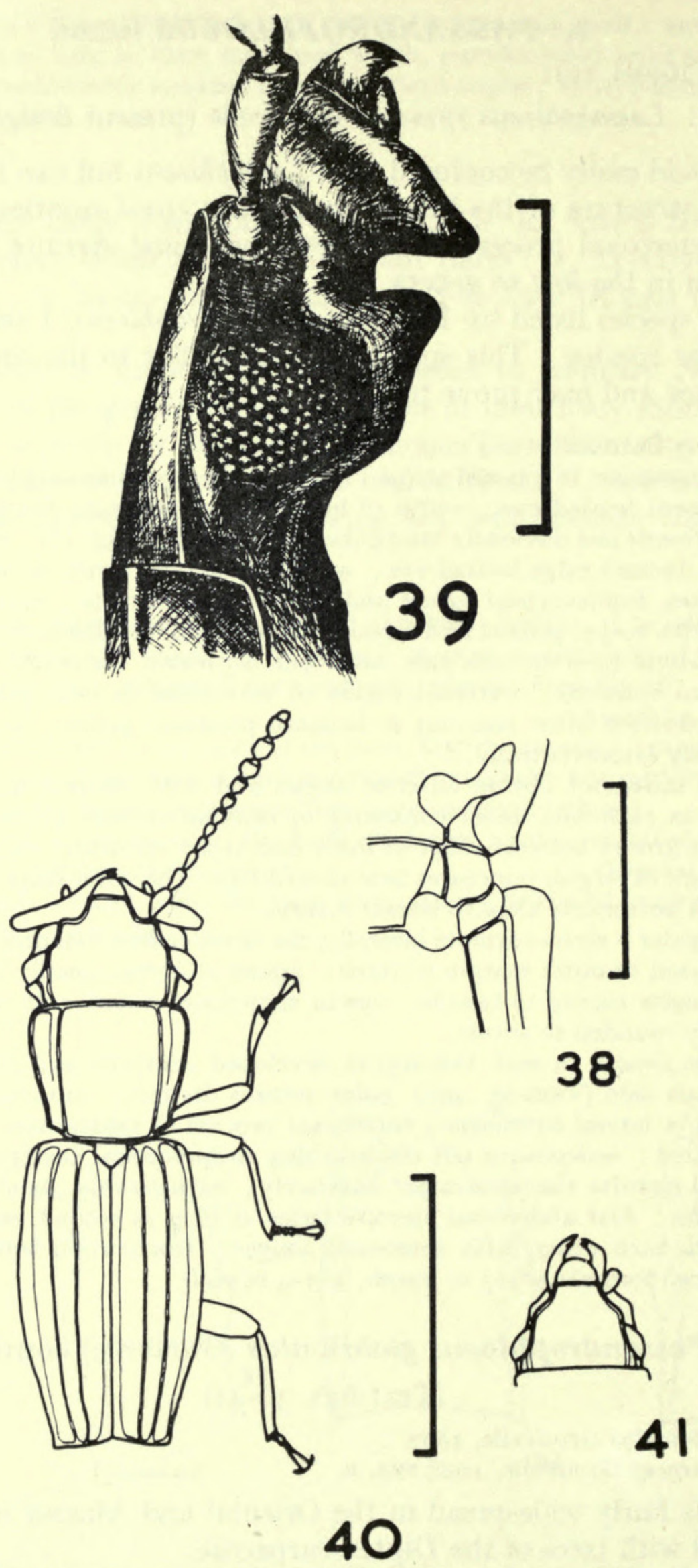

FIgs. 38-4I. Passandrophloeus glabriculus; (38) Front and middle coxal cavities; (39) lateral view of head of male ; (40) dorsal view of male ; (4I) dorsal view of head of female.

Scale lines: Figs. $38,39=0.25 \mathrm{~mm}$. ; Figs. $40,4^{I}=\mathrm{I} \mathrm{mm}$. 
Punctures on head and disc of pronotum slightly smaller in diameter than facet of eyes, separated by once to four times their diameter, each with a seta about two diameters in length.

Pronotum about as long as broad, narrowed basally; elytra at shoulders as broad as pronotum apically, broadening until just posterior to their mid-point where, in male, they are as broad as head across eyes and in females, broader than head ; first strial interval of elytra in addition to contributing to first cell, possesses a row of punctures situated quite close to suture ; the three cells each with row of punctures in addition to two punctured striae; secondary intervals very narrow (these are presumably what Grouvelle in his original description, called the striae since he described each elytron as having three striae).

In the Grouvelle collection there are three males, which I consider to be syntypes of this species: two are mounted together and bear the data "Sumatra Deli/Type [black printed on white]/Laemophloeus glabriculus Grouv ty". The lectotype, which I now select, is the male on the right and has been indicated by the figure 2 on the card. The remaining paralectotype bears the data "Sumatra tabac/Type [black printed on white]".

The holotype of L. divergens bears the following data; "Af. or. All. Amani/ Eichelbaum/Type [mss]/Laemophloeus divergens sp. nv. Grouv." and a Paris museum type label. When examined it was found to be the same species as $P$. glabriculus. Lefkovitch (I957a) gave a record of this species arriving at a British port on dunnage from West Africa, which suggested that the species, previously known only from Sumatra, occurred in Africa. The following data on the specimens given below confirms that the species does in fact occur there.

Congo, West Africa.

I "Yangambi, I95I C. Donis z.309 Com. et Bois Congo r.2326" and 3 other speci-

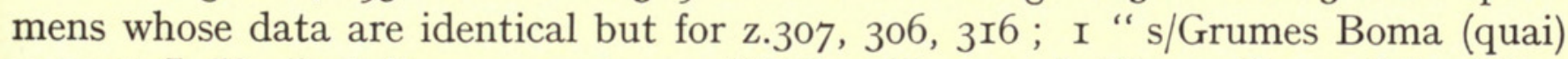
X-I945 J. Vrydagh" ; I4 specimens "Eala viii-I935 J. Ghesquière 708" ; (Mus. R. Congo Belge). Five specimens (author's collection) "Palm kernels loaded Apapa 23-i-I957 next to damp, moulding logs ss.Martita collected I8.ii. I957 R. C. Welch at Bristol " (these last are the specimens referred to in Lefkovitch, I957).

Certain other species hitherto placed in Laemophloeus properly belong to this genus, namely Passandrophloeus ditomoides (Grouvelle) comb. n., P. spinosus (Grouvelle) comb. n. and P. falcidens (Grouvelle) comb. n.

\section{MESTOLAEMUS gen. n.}

Type species: Mestolaemus longicornis sp. $\mathrm{n}$.

The beetles belonging to this curious genus can be distinguished at once from other African Laemophloeinae by the very deep outer emargination on the front of the head.

I.5 mm.; body flattened.

Head broader than long; eyes moderate in size, situated just more than one diameter in advance of base; frontoclypeal suture obsolete; epistome emarginate anteriorly, between epistome and insertions of antennae two further emarginations on each side, outermost very deep; lateral raised line present and additional short line present behind eye ; antennae with all segments elongate, in total longer than body. 
Pronotum with lateral line carinate, this line without a fovea along its length.

Scutellum flatly triangular; elytra with the three cells ; the usual inflected lateral region typical of Laemophloeinae hardly deflected but explanate.

Genae not produced; gular sutures distinct; anterior coxal cavities narrowly closed behind, coxae spherical and well separated from each other; mesepimeron contributing appreciably to mesocoxal cavity ; metasternum about equal in length to first two abdominal sternites ; intercoxal process of first abdominal sternite straight anteriorly ; first abdominal sternite twice as long as second in mid-line, second to fourth subequal, fifth slightly longer; in overall shape, abdominal sternites strongly convex, abdomen consequently semicylindrical in shape; legs subequal in length ; trochantero-femoral junctions of normal type ; hind femora slightly more dilated than others; tarsal formula $5-5-5$ in male, female unknown (probably 5-5-5).

\section{Mestolaemus longicornis sp. $\mathrm{n}$.}

\section{(Text-fig. 43)}

$\mathrm{I} \cdot 5^{-2} \cdot \mathrm{O} \mathrm{mm}$; body very flattened; reddish yellow in colour.

Head transverse, about twice as broad as long ; labral emargination shallow ; region between outer deep emargination and eye strongly produced above antennal insertion; scape about twice as long as broad, other segments three to four times as long as broad; all segments of antennae about as long as each other, antenna about equal to body in length ; last three segments hardly if at all broader than those preceding; surface closely and evenly punctured, diameter slightly less than that of an eye facet, separated by half to one and a half times this distance, each with a short, stout seta about equal to one and a half diameters in length; surface between punctures smooth and shining.

Pronotum at the acute, produced anterior angles as broad as head, twice as broad as long; posterior angles slightly obtuse; lateral margin (including anterior angles) with about six rounded teeth, these being more strongly developed anteriorly; lateral line formed by a raised ridge ; sublateral region explanate; surface with puncturation and setation as on head.

Elytra oval in shape, broadest at their mid-point, there slightly broader than pronotum, slightly longer than their combined width; cells with two or three rows of punctures additional to striae ; each elytron carinate laterally, sublateral region explanate ; setae as long as those on head and pronotum.

West Africa, Angola.

Holotype male " Angola I493,I8.2./Rives Chumbe, 40 km. E. de Dundo, galerie for., detritus sol. I5-V-I949. A. de Barros Machado" (British Museum (Natural History)); I paratype male "IFAN-I946 Tonkoui C.I. 900-I200 m. A. Villiers Forêt Prim. 20-30.ix"' (Muséum National d'Histoire Naturelle, Paris).

\section{MARIOLAEMUS gen. $\mathrm{n}$.}

\section{Type species : Laemophloeus misellus Grouvelle.}

$\mathrm{I} \cdot 5^{-2} \cdot 3 \mathrm{~mm}$; body only slightly flattened and rather broader in general build than is usual in the subfamily.

Head somewhat transverse ; eyes moderate in size, situated in advance of base ; frontoclypeal suture obsolete ; epistome trisinuate ; mouthparts projecting ; antennae elongate, not clubbed, segments increasing in length from fourth to eleventh; third segment longer than either second or fourth; lateral line represented by raised ridge ; a short additional line behind eye present.

Pronotum transverse, narrowed basally, anterior and posterior angles acute; lateral line represented by raised ridge, broadening laterally at base ; just behind mid-point in sublateral region a deeply impressed line with posterior obliquity. 
Scutellum transversely pentagonal; elytra rarely twice as long as their combined width, usually only one and a half times or somewhat less ; first cell strongly margined internally at base, other cells weakly developed ; greater part of last abdominal tergite often exposed dorsally.

Genae normal ; gular sutures distinct; anterior coxal cavities closed posteriorly, circular but coxae very clearly transverse internally; prosternal intercoxal process concave posteriorly; metepisternum not contributing to mesocoxal cavity ; intercoxal process of first visible abdominal sternite slightly curved anteriorly ; metasternum about as long as first two abdominal sternites ; first abdominal sternite twice as long as second, second to fourth subequal in length, fifth somewhat longer, trochantero-femoral junctions of normal type ; legs subequal ; tarsal formula 5-5-5 in female, $5^{-5-4}$ in male.

This genus is not unlike Phloeipsius Casey in its general appearance, but the two are not really closely related. Mariolaemus can be distinguished from Phloeipsius by the strongly formed frontoclypeal suture and the greater degree of flattening in the body. Mariolaemus can be distinguished from other African genera by the characters given in the key.
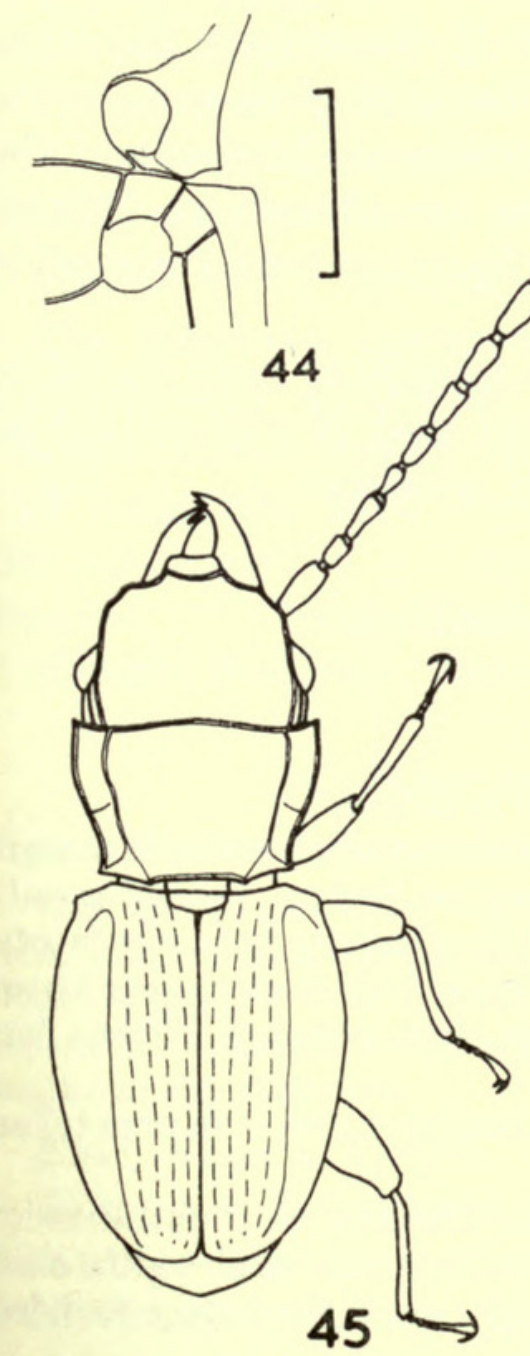
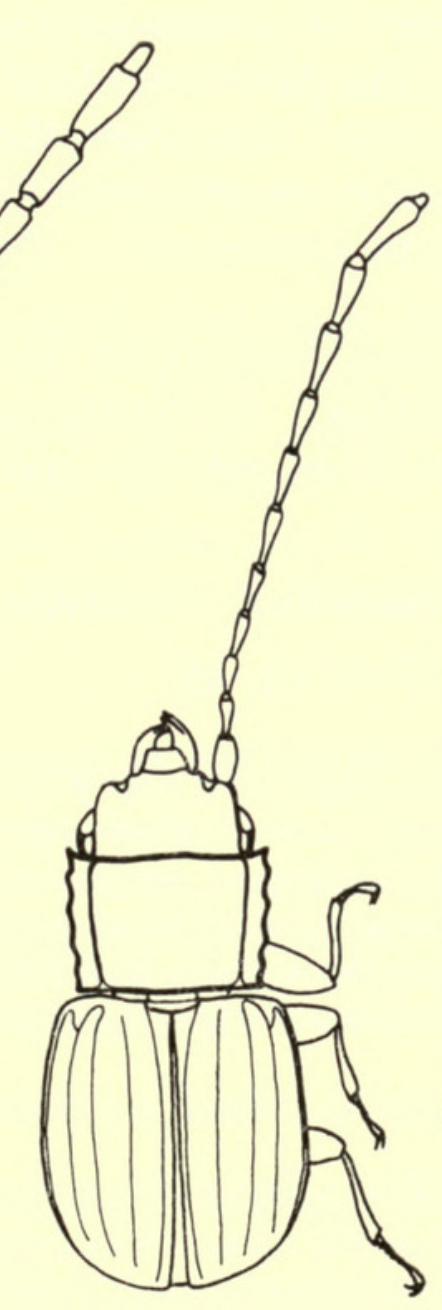

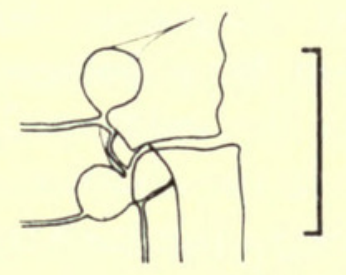

42

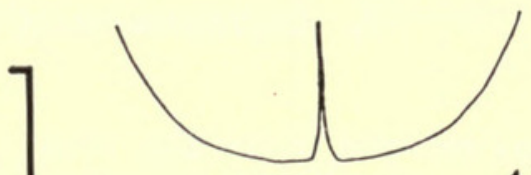

46

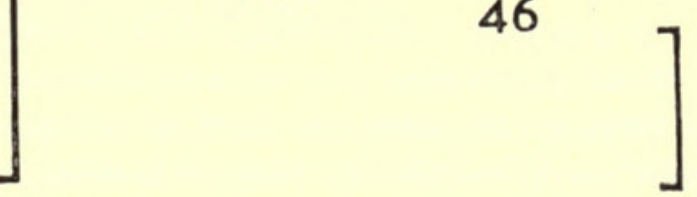

43

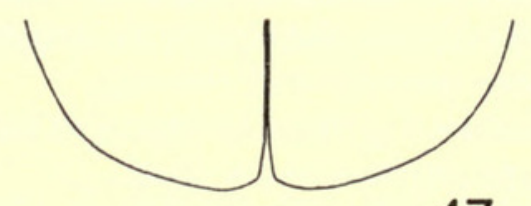

47

FIgS. 42-47. (42) Front and middle coxal cavities of Mestolaemus longicornis; (43) dorsal view of $M$. longicornis; (44) front and middle coxal cavities of Mariolaemus misellus ; (45) dorsal view of M. misellus ; (46) apices of elytra of M. escalerae and (47) of $M$. misellus.

Scale lines: Figs. $42,44,46,47=0.25 \mathrm{~mm}$. ; Figs. $43,45=\mathrm{I} \mathrm{mm}$. 


\section{Key to Species}

x. Elytra about $\mathrm{I} \cdot 5$ or more times as long as their combined width .

- Elytra less than I.45 times as long as their combined width .

2. Head with a striole at the base of the antennae; body slightly convex

I. livens (Grouvelle) (p. 2I8)

- Head without a striole at the base of the antennae ; body distinctly convex (blackish red in colour, with a shining region at the base of the antennae)

4. eichelbaumi (Grouvelle) (p. 219)

3. Elytra of greatest length at their apico-sutural angles (Text-fig. 46); abdomen usually entirely covered by the elytra; elytra at their broadest wider than the pronotum at its maximum width . . . . 3. escalerai (Grouvelle) (p. 219)

- Elytra of greatest length between their external and their apico-sutural angles and the base; tip of abdomen often exposed dorsally; elytra at their broadest as broad as the pronotum at its widest

2. misellus (Grouvelle) (p. 218)

\section{Mariolaemus livens (Grouvelle) comb. n.}

Laemophloeus livens Grouvelle, I923.

The length of the elytra distinguishes $M$. eichelbaumi and $M$. livens from the other two species of the genus; however, the differences that Grouvelle gave to separate $M$. livens from $M$. eichelbaumi (the lesser convexity, the striole at the bases of the antennae and the sublateral impression on the pronotum) are characters difficult to appreciate in the absence of the type specimen(s) ; they have not been discernible in any specimen examined by me.

The type of this species has not been located nor have specimens been found to correspond with the original description. Grouvelle stated that it was related to $M$. eichelbaumi most closely and also to $M$. misellus and $M$. escalerai.

EAST AFRICA.

\section{Mariolaemus misellus (Grouvelle) comb. n.}

\section{(Text-fig. 45)}

Laemophloeus misellus Grouvelle, I889.

I 7-2.0 mm. ; body black with a reddish tinge, tarsi yellow to red in colour.

Head transverse, $\mathrm{I} \cdot 5$ times as wide as long ; a short, shallow groove situated on anterior margin of impunctate area at base of antennae, antennae about as long as body; surface evenly punctured (except for area at base of antennae), punctures smaller in diameter than eye facets, separated by distance equal to two to five times their diameter; each with a short seta about equal to three diameters in length; surface between punctures with micro-punctures but otherwise smooth and shining.

Pronotum I. 5 times as broad as long, as broad as head, narrowing basally ; disc with punctures, setae and surface as on head.

Elytra slightly broader across shoulders than base of pronotum, broadest at about anterior third, as broad as pronotum at widest; elytra $I \cdot 2$ times as long as their combined width, each with punctured striae ; third cell developed internally and anteriorly ; each separately rounded to apico-sutural angle; last segment of abdomen exposed dorsally.

There are 2 syntypes in the Grouvelle collection; I select a specimen with the following data as lectotype (it appears to be the specimen figured in the original description): "Assinie Côte occid. Afrique Ch. Alluaud r886/Type/Laemophloeus misellus Grouv." The paralectotype, which is the same species as the lectotype, 
bears the following data; " Assinie Afrique oc [printed on green paper]/Type [black printed on white]/Laemophloeus misellus Grouv [mss]/Type [black printed on red]."

This species is one of the commonest of the African Laemophloeinae not associated with stored products, and is widespread in its distribution. I have seen specimens from Abyssinia, the Ivory Coast, the Congo, Uganda, Angola and South Africa.

\section{Mariolaemus escalerai (Grouvelle) ${ }^{1}$ emend. comb. $\mathbf{n}$.}

Laemophloeus escalerae Grouvelle, I905.

Laemophloeus subniger Grouvelle, I905, syn. $\mathbf{n}$.

This species resembles $M$. misellus (Grouvelle) very closely but differs as follows : head and pronotum with very few if any micropunctures between punctures ; pronotum slightly broader than head ; elytra across shoulders as broad as greatest breadth of pronotum, at anterior third distinctly broader ; elytra evenly rounded together apically.

There are 3 syntypes of $M$. escalarai (Grouvelle) in the Grouvelle collection. I select a specimen with the data)" Biaffra Escalera" as lectotype. The other two syntypes, which are mounted together, bear the data; "Biafra Cabo S. Juan VII-I9or Escalera/Type [mss]/L. Escalerae Grouv. ty. [Grouvelle's mss]" and a Paris museum type label. They are conspecific with the lectotype. The holotype of $L$. subniger Grouvelle, whose data are "Assinie Côte occid. Afrique Ch. Alluaud I886/L. subniger Gr. ty ined.”, is the same species as M. escalerai.

Congo, West Africa.

The following specimens have also been seen: 2 "Stanleyville: Yangambi I/I6-xii-I953. J. Decelle”; I "Haut-Uele: Moto vi/vii-I923 L. Burgeon”; I "Coquihatville, roo km en amout de, sur le fleure à la lumière 3-v-I949. N. Leleup "; I "Yangambi 20-ix-I952 Dr. K. Schedl"; I "Congo Belge Leopoldville L. Burgeon I9I7"; 3 "Ogoone Lambarene R. Ellenberger I9II" (Mus. R. Congo Belge) ; 2 "Yaule/Nimba (Guinee) M. Lamotte 2-vi-I942" (Muséum National d'Histoire Naturelle, Paris).

\section{Mariolaemus eichelbaumi (Grouvelle) comb. $\mathbf{n}$.}

Laemophloeus eichelbaumi Grouvelle, I908.

This species resembles both $M$. misellus and $M$. escalerai but differs in having no groove or stria anterior to the impunctate region at the base of the antennae and in the elytra being more than 1.5 times as long as their combined width; it resembles $M$. misellus in having each elytron separately rounded to the apico-sutural angle and $M$. escalevai in the non-exposure of the last tergite of the abdomen.

EAst Africa, Congo.

There are 8 syntypes in the Grouvelle collection; I select the one with the following data as lectotype: "Af. or. all. Amani/I9/Laemophloeus eichelbaumi inéd. Grouv." All the other syntypes bear the following data : "Afr. or. all Amani ", and two additionally: "Eichelbaum" on a separate label.

Grouvelle describes this species as being common at Amani during the months of July to November. Two specimens have been examined other than the syntypes,

${ }^{1}$ The emendation accords with the provisions of Article $3 \mathrm{I}$ of the International Code of Zoological Nomenclature, I96I. 
both from the Belgian Congo. One (British Museum (Natural History)), bears the following data: "I8 m. S.W. of Elizabethville I928 Dr. H. S. Evans"; the other (Mus. R. Congo Belge), " Elizabethville-ii-I940 H. J. Bredo ”.

\section{NOTOLAEMUS Lefkovitch}

Notolaemus Lefkovitch, I959b.

\section{Type species: Cucujus unifasciatus Latreille (by original designation).}

2-3 mm.; body moderately flattened.

Head somewhat wider than long; eyes moderately prominent, situated in advance of base and occupying less than one half of lateral margin of head; front margin of head with a central labral, paired mandibular and often small antennal emarginations; antennae about equal in length in both sexes, approaching length of body; last three segments not forming a distinct club ; lateral line represented by raised ridge ; a subsidiary ridge behind eye present in addition.

Pronotum transverse, narrowed basally ; anterior and posterior angles moderately prominent lateral margin sometimes irregularly rounded; lateral line represented by raised ridge which is somewhat broadened basally.

Scutellum triangular; elytra often leaving the tip of abdomen exposed dorsally; the three cells present or absent; outer margin of third cell when present may or may not coincide with lateral carina.

Genae normal ; gular sutures distinct; anterior coxal cavities widely open posteriorly ; coxae globular ; prosternal intercoxal process slightly convex posteriorly ; metepimera not contributing to mesocoxal cavities; posterior border of mesosternum very slightly convex posteriorly; metasternum about as long as first two abdominal sternites, median line broadening towards anterior margin ; intercoxal process of first visible abdominal sternite slightly curved anteriorly ; this sternite twice as long as second, second to fifth sterites subequal; trochantero-femoral junctions of normal type although approaching heteromeroid type in middle and hind legs; legs subequal in length, middle femora slightly less dilated than front or hind; tarsal formula 5-5-5 in female, 5-5-4 in male.

\section{Key to African Species}

I. Pronotum with two well separated lateral lines on each side

- Pronotum with one lateral line on each side

I. perrieri (Grouvelle) (p. 22I)

2. Mandibles of the male broadly produced laterally (Text-fig. 48 ) .

- Mandibles not produced laterally but rounded

3. Hind angles of the pronotum acute or rectangular

- Hind angles of the pronotum obtuse .

4. Pronotum with a short, longitudinal deep impression on each side external to the lateral carina and adjacent to it at its mid-point (Text-fig. 49)

3. perspicuus (Grouvelle) (p. 222)

- Pronotum with a transverse, impressed line between the lateral carina and the lateral margin at its mid-point (Text-fig. 50)

4. riartus sp. n. (p. 223)

5. Pronotum excavate sublaterally (Text-fig. 5I); body brown 5. clarus (Grouvelle) (p. 223)

- Pronotum flattened sublaterally (Text-fig. 52); body brown or black

2. elli sp. n. (p. 22I)

6. Body black and rather dull

8. picinus (Grouvelle) (p. 226)

- Body brown and rather shining

7. Head with a deep transverse groove on each side at the bases of the antennae; body $2.5 \mathrm{~mm}$. in length or more . . . . . 6. peringueyi (Grouvelle) (p. 224)

- Head at most with a shallow fovea on each side at the bases of the antennae, usually non-foveate and flat; body rarely longer than $2.3 \mathrm{~mm}$., usually $2.0 \mathrm{~mm}$. or less in length

7. liganus $\mathrm{sp}$. n. (p. 225) 


\section{Notolaemus perrieri (Grouvelle) comb. n.}

Laemophloeus perrieri Grouvelle, I906.

This species differs from other Notolaemus in possessing two lateral lines on each side on the head and pronotum, and in the broadness of the head.

$2 \mathrm{~mm}$.; brown in colour; head and pronotum covered with short, fine setae; punctures almost invisible.

Head transverse, broader across eyes than pronotum at widest, with two lateral lines on each side ; eyes one diameter in advance of base ; antennae about as long as body.

Pronotum I.3 times as broad as long, broadest just behind anterior angles ; two lateral lines on each side, distance between inner and outer equal to that between outer and lateral margin; anterior angles acute, posterior angles obtuse.

Elytra $\mathrm{I} \cdot 5$ times as long as their combined width, evenly rounded to apico-sutural angle.

Female unknown.

HoLOtype male "Madagascar/Perrier/Type/Laemophloeus perrieri Grouv." (Grouvelle collection). A second male, with the following data, has been seen: "Zamscolla ix-I952 R.P. Institut Scientifique Madagascar" (Muséum National d'Histoire Naturelle, Paris).

\section{Notolaemus elli sp. n.}

(Text-fig. 48)

This species is distinct from other Notolaemus in that the mandibles of the male are strongly produced laterally and the exiernal angles of the central epistomal

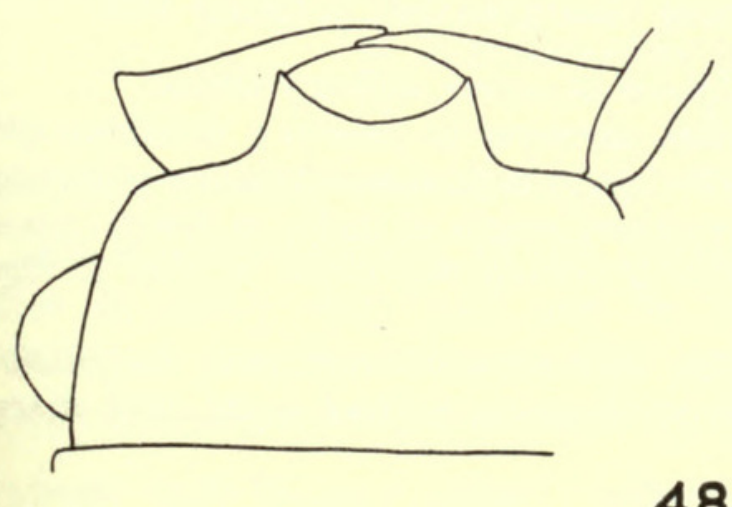

48
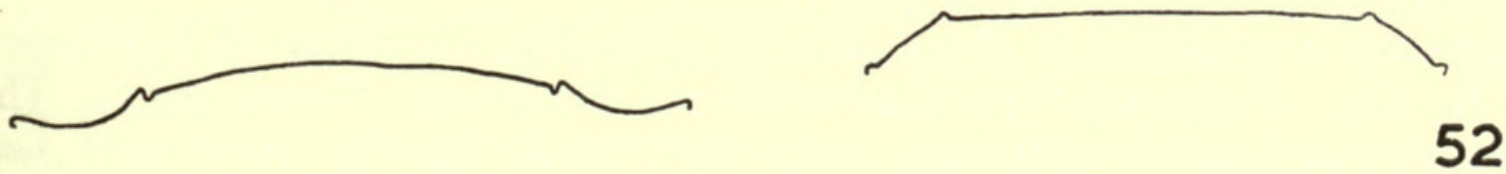

\section{1}

Figs. 48-52. (48) Head of Notolaemus elli; (49) sublateral region of pronotum of $N$. perspicuus and (50) of $N$. riartus ; (5I) transverse section of pronotum of $N$. clarus and (52) of $N$. peringueyi. 
emargination are produced anteriorly, recalling the condition in Planolestes; however, the characters included in the key to genera serve to distinguish this species from those of that genus.

$2 \cdot \mathrm{I}-2.5 \mathrm{~mm}$.; head and pronotum dark red, elytra more yellow in colour.

Head widest across eyes, broader than pronotum; labral emargination of epistome with external angle somewhat produced anteriorly, recalling those of a small male Planolestes; antennae as long as body in males, shorter in females; surface of disc punctured, punctures small, circular and separated by once to three times their diameter, each subtending a seta ; mandibles of males often strongly produced laterally resembling a claw-hammer in general appearance.

Pronotum broader anteriorly than posteriorly in males, about same width in females; surface with puncturation and setae as on head.

Elytra evenly rounded to apico-sutural angles.

\section{Congo.}

Holotype male "Maceo (Luebo) 23-ix-I92I Dr. H. Schouteden "; paratypes : I with the same data as the holotype (female) ; 4 " Kamalembi (Luebo) 2I-ix-I92I Dr. H. Schouteden ” (2 males and 2 females) (Mus. R. Congo Belge).

\section{Notolaemus perspicuus (Grouvelle) comb. n.}

(Text-fig. 49)

Laemophloeus perspicuus Grouvelle, I899.

This species is most closely related to $N$. elli sp. n. but can be distinguished from it in that the mandibles of the male are not produced laterally and that the production of the external angles of the median epistomal emargination is much less.

$2 \cdot 0-2 \cdot 5 \mathrm{~mm}$.; shining; head and pronotum reddish brown in colour, elytra yellower.

Head in males about as broad as pronotum, somewhat narrower in females; epistome with outer pair of emarginations not developed ; outer margins of the central emargination somewhat produced anteriorly; antennae in males about three-quarters length of body, in females about half length of body; surface of head with small, circular punctures separated by once to three times their diameter, this surface smooth.

Pronotum broadest between anterior angles in males, somewhat behind them in females; anterior angles obtuse and rounded, posterior angles rectangular or just acute and sharp; puncturation and setation as on head.

Elytra about $\mathrm{I} \cdot 75$ times as long as their combined width.

\section{Rhodesia, Congo, South Africa.}

There are 4 syntypes in the Grouvelle collection: I select as lectotype a male "C. B. Esp. Peringuey/Type/Laemophloeus perspicuus Grouv. ty". The three other syntypes have the following data : two "C. B. Esp "; one "C. B .Esp./Type [black printed on white]/I04". Other specimens seen include 2 "Kunungi 9-ivI92I Dr. H. Schouteden"; 2 "Ubangi I-ii-I93I M. Leontovitch"; I "Arebi vii-I925 Dr. H. Schouteden"; I (female) "Haut-Uele: Adra 23-iv-I925 Dr. H. Schouteden" (Mus. R. Congo Belge); 3 "N.W. Rhodesia Shigariatombwes, 30-vi-I9I3 H. C. Dollman" (British Museum (Natural History)). 


\section{Notolaemus riartus $\mathbf{s p}$. $\mathrm{n}$.}

(Text-fig. 50)

Closest to $N$. perspicuns (Grouvelle) with which it could easily be confused. In addition to the transverse line between the lateral carina and lateral margin, $N$. riartus is a dirty yellow in colour rather than reddish brown, is less convex than $N$. perspicuus and has the sides of pronotum more smoothly rounded.

$\mathrm{I} \cdot 8-2 \cdot 3 \mathrm{~mm}$.; moderately shining; body fuscous yellow in colour, elytra almost transparent.

Head in males as broad as or broader than pronotum, somewhat narrower in females; epistome with outer pair of emarginations weakly developed, outer margins of the labral emargination somewhat produced anteriorly ; antennae almost as long as body in males, shorter in females ; surface of head punctured, surface micro-reticulate between them.

Pronotum broadest behind anterior angles in both sexes ; anterior angles obtuse and rounded, posterior angles slightly acute and moderately sharp; surface ornamented as on head.

Elytra $\mathrm{I} \cdot 75^{-2} \cdot 0$ times as long as their combined width, sometimes leaving tip of abdomen exposed dorsally.

Rhodesia, Congo, Angola.

Holotype and 2 paratypes "Angola 4II7.I5-Alto Cuilo, Poste de Cacolo, gal. forest. missean Tcha-Muchito, 2-vi-54. A. de Barros Machado" ; other paratypes: 3 "Angola 4II9.3 Alto Cuilo (Cacolo) vi-54. A. de Barros Machado"; I "Angola 4072.6-Alto Cuilo, Poste de Catolo, rives de la Cavuemba, detr. sol. 26-v-54. A. de Barros Machado" ; I "Angola 4II6.20 (as 4072.6)" ; I "N.W. Rhodesia Shigariatombwes 8-vii-I9r3 H. C. Dollman" (British Museum (Natural History)) ; 3 " Miss. H. de Saeger 3384" (see Appendix) ; 2 "Ubangi I-ii-I93I" ; I “Arebi vii-I925 Dr. H. Schouteden” (Mus. R. Congo Belge).

\section{Notolaemus clarus (Grouvelle) comb. $\mathbf{n}$.}

(Text-fig. 5I)

Laemophloeus clarus Grouvelle, I899.

This species is closest to the European $N$. castaneus (Erichson). The two species differ in many ways and can be most easily distinguished in the region of the scutellum; in $N$. castaneus the scutellum is darker in colour than the adjacent parts of the elytra, whereas in $N$. clarus it is lighter.

$3 \mathrm{~mm}$.; dark brown in colour; surface somewhat dull.

Front of head with five emarginations ; slightly narrower across eyes than pronotum at its widest; surface of head closely punctured, punctures circular, separated by one half of their diameter, surface between them with a fine micro-sculpture ; each puncture with a seta about equal to one to one and one half times their diameter in length; antennae as long as body in male (female unknown).

Pronotum somewhat irregularly rounded laterally; front angles acute, posterior angles obtuse; sublateral region somewhat explanate; puncturation, setation and micro-sculpture as on head.

Elytra twice as long as their combined width.

South Africa, EAst Africa.

Holotype "C.B. Esp. Perinta [= Peringuey?]/Type/ro3/Laemophloeus clarus 
Grouv. ty." One other specimen has been seen, a male "Africa or. Katona/Kilimandjaro X-I904" (Magyar Nemzeti Museum, Budapest (ex Reitter coll.)).

\title{
6. Notolaemus peringueyi (Grouvelle) comb. $\mathrm{n}$.
}

\author{
(Text-fig. 52)
}

Laemophloeus peringueyi Grouvelle, 1899.

A very variable species. One of the most characteristic and constant features is the diagonal grooving of the disc of the head just anterior to the antennae. These grooves appear to be indicative of the frontoclypeal suture, but since the impressed median line ends anteriorly in advance of the median junction of these grooves, the latter cannot be considered to be homologous with those of Placonotus.

2.5-3.0 $\mathrm{mm}$.; reddish brown in colour.

Head as broad across eyes as pronotum at widest; antennae as long as body in the male, all segments elongate ; in female, antennae about three-quarters body length, segments less elongate and with last three segments forming a distinct club; surface of head simply punctured, punctures separated by two to three times their diameter, each with a seta about two diameters in length ; surface between punctures with micro-reticulation.

Pronotum transverse, at its widest $\mathrm{I} \cdot 3-\mathrm{I} \cdot 6$ times as wide as long, broadest just behind anterior angles, narrowing basally; anterior angles acute and rounded, posterior obtuse but sharper ; surface ornamented as head.

Elytra twice as long as their combined width, evenly rounded apically, giving elytra a truncated elliptical shape.

Additional characters are given by Grouvelle in his original description of the species.

\section{South Africa.}

Grouvelle, in his original description, indicated that the syntypes of this species were in the Cape Museum and in his own collection. In the South African Museum, there is a single specimen (male) with the following data ; " CT 5.86/CT 9.86 Under bark/I02 [black printed on white]/Laemophloeus Peringueyi Grouv. ty [Grouvelle's mss] ". In the Grouvelle collection, there are two specimens which I consider to be syntypes of this species, a male " C.B.Es. Raffray/Type [black printed on white]/ Laemophloeus Peringueyi Grouv ty." and a Paris museum type label, and a female " C.B. Esp. Peringuey/Type [black printed on white] ro5 [black printed on white]" and a Paris museum type label. Another specimen in the Grouvelle collection which may be a syntype bears the data " C.B. Esp. Raffray " written with a different colour ink on differently coloured paper from the other Raffray specimen. There is yet another specimen of this species which should be mentioned, which although bearing a type label, is not a syntype of any properly described species. Its data are "Le Cap Chevrolet [sic]/Type [black printed on white]/Laemophloeus capensis Chevr [and an illegible word which might be D'tege] ". This species has never been validly published, so far as it has been possible to discover, and is not listed by Hetschko (I930). I now select the male belonging to the South African Museum to be lectotype.

I have examined the following specimens of the species: 24 "Port St. John Pondoland Sept. I923/R. E. Turner"; I "Natal: Van Reenan, Drakensberg 
55-6500 ft. X-I926/R. E. Turner"; I "Natal: Kloof I500 ft. Sept. I926/R. E. Turner" ; I " E. Cope Prov. Hogsback 4000 ft. I0-X-I932/R. E. Turner " ; 4 "E. Cape Prov. Katberg I/I3-xi-I932/R. E. Turner" ; 3 "E. Cape Prov. Katberg $4000 \mathrm{ft}$ I4/26-xi-I932/R. E. Turner"; 2 "E. Cape Prov. Katberg $4000 \mathrm{ft}$. xiiI932/R. E. Turner" ; 6 "Zululand: Eshowe I-22-iv-926/R. E. Turner” ; I "George, Cape Prov. 27-vi to I-vii-I920/ R. E. Turner" I "Orange Free State: Witziesnoek. 6roo ft. 24-ii-I929/Dr. Hugh Scott" ; I "Estcourt, Natal. G. A. K. Marshall " ; I6 "Stn. No. 59, Deepwalls Forest. Knysna I6-iii-I954 under bark of Yellow-wood, I725 ft. Cape Province J. Balfour-Browne, B.M. I954-797 " ; 2, as previous I6 but dated I7. iii. I954 and " small pool in glade, I725 ft." (British Museum (Natural History)).

\section{Notolaemus liganus sp. n.}

This species resembles $N$. peringueyi (Grouvelle) but differs in that it is smaller, is a dirty yellow in colour and does not have the diagonal grooving anteriorly on the head.

I $5-2 \cdot 3 \mathrm{~mm}$.; blackish yellow in colour, moderately shining.

Head slightly narrower across eyes than pronotum at broadest; antennae almost as long as body in males, segments elongate, ninth segment slightly longer (c. I.25 times) than tenth; in females, terminal three segments slightly more thickened than third to eighth ; surface of head with punctures equal in diameter to an eye facet, separated usually by once but sometimes as much as twice times their diameter, each with a seta equal to two diameters in length; surface between punctures smooth and shining.

Pronotum transverse, about $\mathrm{I} \cdot 25$ times as broad as long; moderately convex, broadest at about anterior third; anterior angles rectangular but not sharp, posterior angles obtuse ; surface ornamented as on head.

Elytra $2 \cdot 0-2 \cdot 2$ times as long as their combined width, together evenly rounded apically, broadest at about mid-point.

Congo, Angola.

Holotype and I paratype " Miss. H. de Saeger 4007 ” ; other paratypes I " Miss. H. de Saeger 3I86 " ; 2 " Miss. H. de Saeger 3235 ” ; 5 “"Miss. H. de Saeger 3296 ” ; 3 “"Miss. H. de Saeger 3384” ; 2 “ Miss. H. de Saeger 35I9” (see Appendix) (Mus. R. Congo Belge) ; I "Angola 4076.I.5--Gal. forest. riv. Tcha-Pemba, affl. Luangue, Poste de Xa-Cassan, 26-v-54. A. de Barros Machado" ; 4 "Angola 4072.6-Alto Cuilo, Poste de Cacalo, rives de la Caouemba, detr. sol. 26-v-54. A. de Barros Machado"; 2 "Angola 4II6.20 (as for 4072.6)"; 3 "Angola 4II8.9-Gal. Forest. riv. Lunguena, affl. Luangue, Poste Xa-Cassan, 7-vi-54. A. de Barros Machado" ; I "Angola 4I68. I2 Alto Chicapot, dans les mousses d'une cascade, 24-vi-54. A. de Barros Machado " ; I "Angola 4276. I6-Alto Chicapa, gal. forest ; riv. Tchirimbo, detr. sol. 9-vii-54. A. de Barros Machado" ; I "Angola 4I25.35Alto Cuilo, Cacolo, rives ruisseau Na-Ipanha, detr. sol. Io-vi-54. A. de Barros Machado" ; I "Angola 4370.36 Alto Chicapa, gal. for. riv. Tchimboma, detr. sol, I-viii-54. A. de Barros Machado" ; 6 "Angola 4082.I5 (as for 4072.6) " (British Museum (Natural History)). 


\section{Notolaemus picinus (Grouvelle) comb. n.}

Laemophloeus picinus Grouvelle, r923.

This is a very distinct species, being the only black one of its genus ; it most closely resembles the European $N$. unifasciatus (Latreille) in shape and general body proportions but differs in that it is black; the punctures on the head are about twice the diameter of an eye facet and are situated close together.

$N$. picinus is the only species of the unifasciatus group known to occur in Africa, all the other species of the genus in Africa being closer to $N$. castaneus (Erichson).

EAst Africa, Congo.

In addition to the holotype, which bears the data "AFr. OR ANG. (KIKUYUEsct) KiJABE Alluaud et Jeannel Dec. I9II-2I00 m-St. 27 [printed]/Type [black printed on pink]/Laemophloeus picinus Grouv." and a Paris museum type label, I have seen the following specimens : I " Miss. H. de Saeger 3488” ; I "Miss. H. de Saeger, 4007” (see Appendix) (Mus. R. Congo Belge).

\section{PLANOLESTES Lefkovitch}

Planolestes Lefkovitch, I958a.

Type species: Planolestes laevicornis Lefkovitch (by original designation).

In addition to the characters given in the original description, the following points should be noted: head with lateral line represented by raised ridge, median line by shallow groove; pronotum with lateral line represented by a raised ridge; at about middle third a deep groove just internal to ridge ; basally a short, raised secondary ridge internal to primary ridge ; lateral line appears to be a double structure in basal third, dividing into two very close to base, one part turning abruptly to meet hind angles, other continuing to base; gular sutures obsolete ; anterior coxal cavities circular; prosternal process convex posteriorly; mesepimeron and mesepisternum contributing to the mesocoxal cavities; posterior margin of the mesosternum straight ; median line of metasternum not quite reaching anterior margin of sclerite ; trochanterofemoral junctions of normal type.

I am indebted to Mr. J. C. Davies for collecting larvae of Planolestes; these have emphasized the generic separation of Planolestes from Cryptolestes. A full study of these and other Cucujid larvae will be published elsewhere.

No redescriptions of the species belonging to this genus will be given.

\section{Key to Species}

I. Prothorax I.5 times as broad as long; head of male with clypeal horn strongly developed on the left side only, vestigial on the right laevicornis Lefkovitch (p. 228)

- Prothorax less than I.5 times as wide as long, rarely exceeding $\mathrm{I} \cdot 3$ times; head of male with clypeal horns strongly developed on both sides

2. Head coarsely punctured near the median line, punctures longitudinally elongate, separated by about one diameter ; thoracic punctures as those on the head ; setae on disc of thorax about equal in length to that of the punctures

brunneus (Grouvelle) (p. 228)

- Head with very few punctures near the median line, those present being circular, two to four diameters apart; thoracic punctures as those on the head ; no apparent setae on the disc of the thorax

cornutus (Grouvelle) (p. 228) 
Four species were considered by Lefkovitch (I958a) to belong to this genus. The placing of one of these, described originally as Laemophloeus biskrensis Grouvelle was based upon a specimen labelled "type " in the Grouvelle collection. It has since been compared with the true type in the Alluaud collection and found not to be conspecific. In fact L. biskrensis is a Cryptolestes and is considered in this paper under that genus (p. 233). The incorrectly named specimen in the Grouvelle collec-

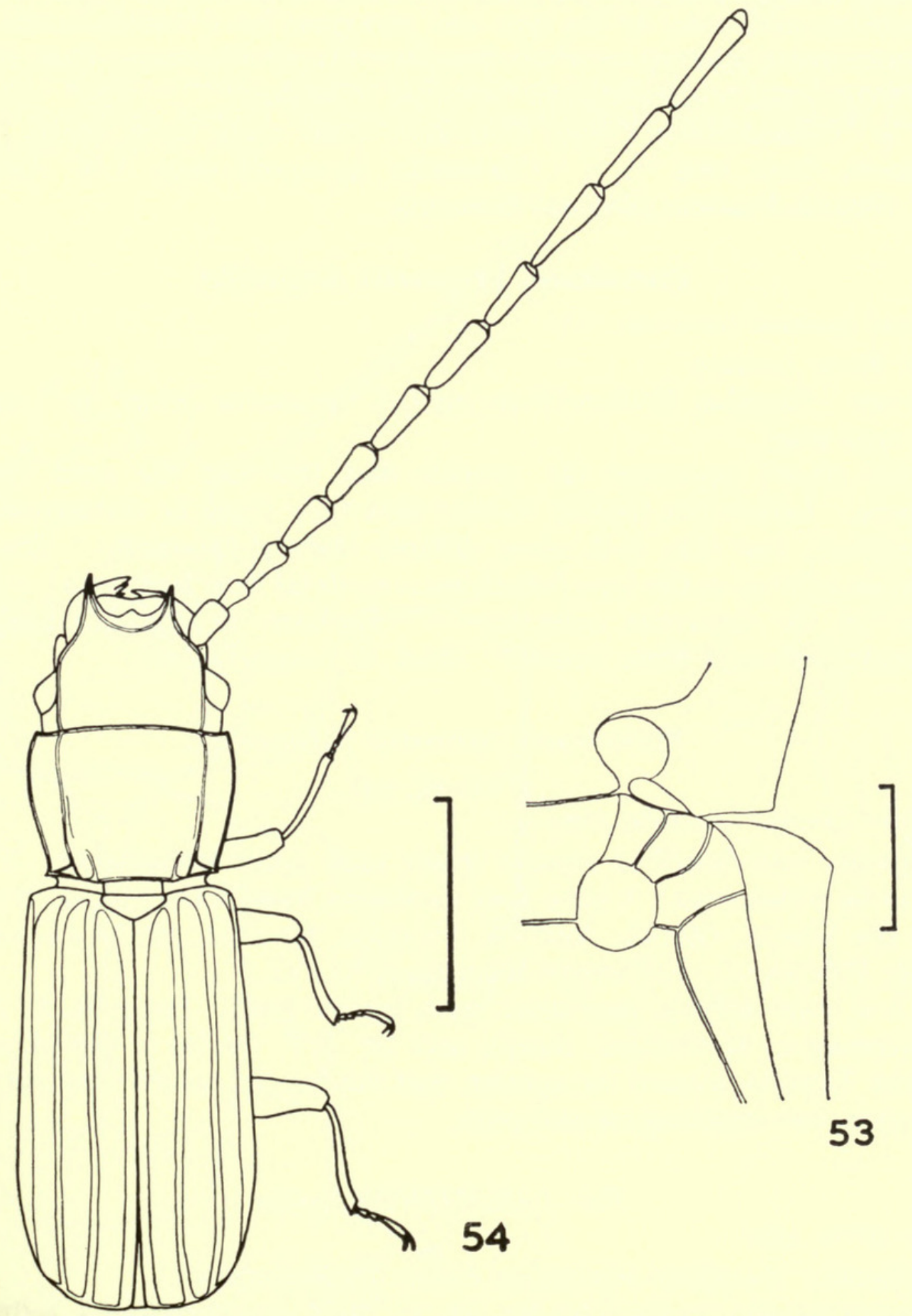

Figs. 53-54. (53) Front and middle coxal cavities of Planolestes cornutus; (54) dorsal view of male $P$. cornutus.

Scale lines: Fig. $53=0.25 \mathrm{~mm}$.; Fig. $54=\mathrm{I} \mathrm{mm}$. 
tion has proved to be a rather aberrent Planolestes cornutus (Grouvelle), agreeing reasonably with the original description of the species with which it had been confused.

\section{Planolestes laevicornis Lefkovitch}

Planolestes laevicornis Lefkovitch, 1958a.

South Africa.

No specimens additional to the type and paratypes have been located.

Holotype and 3 paratypes "Fort Beaufort. C[ape] P[rovince] June I94I. J. W. Geyer. With scale Lecaniodiaspis mimosae [(Maskell)]"; other paratypes as follows : 4 "Grahamstown C[ape] P[rovince.] June I908. C. W. Mally. Emerged from Mimosa thorn twig" ; 3 "Okahandja I9-29-xii-I927. S.W. Africa. R. E Turner" (British Museum (Natural History)).

\section{Planolestes brunneus (Grouvelle)}

Laemophloeus brunneus Grouvelle, 1877.

Congo, EAst Africa.

Holotype "Zanzibar Raffray/Type [mss]/L. brunneus Grouv. ty" and a Paris museum type label.

Grouvelle (I908) expressed the opinion that this and the next species were synonymous. Lefkovitch (I958a) showed that they could be distinguished by the female genitalia and that both sexes differed slightly externally. The following specimens, in additon to the type (which bears no data) have been seen : I " Dimbrey C.B. Esp." in the Grouvelle collection ; I "Bushurn iii-I937 J. Ghesquière ", 7 "Mongbwalu -vii-I938 Mme. Scheitz" (Mus. R. Congo Belge).

\section{Planolestes cornutus (Grouvelle)}

Laemophloeus cornutus Grouvelle, I899.

(Text-fig. 54)

This species was described from a single male from Madagascar. The species appears to be widespread; I have seen specimens from MADAGASCAR, from various parts of the Congo, Ghana, Angola, Uganda, Nigeria, Bechuanaland, Cape Province, Pondoland, Southern Rhodesia, Kenya.

There is a quite definite association with legume pods. Both Mr. F. Ashman of the Department of Agriculture, Kenya, and Mr. J. C. Davies of the Department of Agriculture, Uganda, formed the opinion that this species, which they sent to me for identification, was attacking legume pods.

Cucujinus Arrow, 1920.

\section{CUCUJINUS Arrow}

Type species: Cucujinus micromma Arrow (by monotypy).

This genus is being revised by Mr. W. O. Steel and therefore I include only a generic redescription designed to show its relationship with other African Laemophloeinae. 
Head transverse, with distinct rounded temples, expanding from base; eyes about or more than one diameter in advance of base ; frontoclypeal suture obsolete; front of head between antennae with five emarginations, a shallow labral, paired deep mandibular and a shallow pair between the mandibular and insertions of antennae; antennae about half body length, with a robust scape, small pedicel, slightly elongate third segment, segments increasing in size from fourth to terminal, last three or four segments giving the impression of forming a club but in fact not so ; lateral line represented by a distinct groove, these grooves not joined anteriorly but basally; basally at junction of lateral and transverse grooves a diagonal groove running from junction to base.

Pronotum very transverse, usually more than twice as broad as long ; anterior angles distinct and acute, hind angles rounded ; lateral margin somewhat irregular ; lateral line represented by a distinct groove which does not reach anterior margin, basally curved medially but does not continue across to join the other.
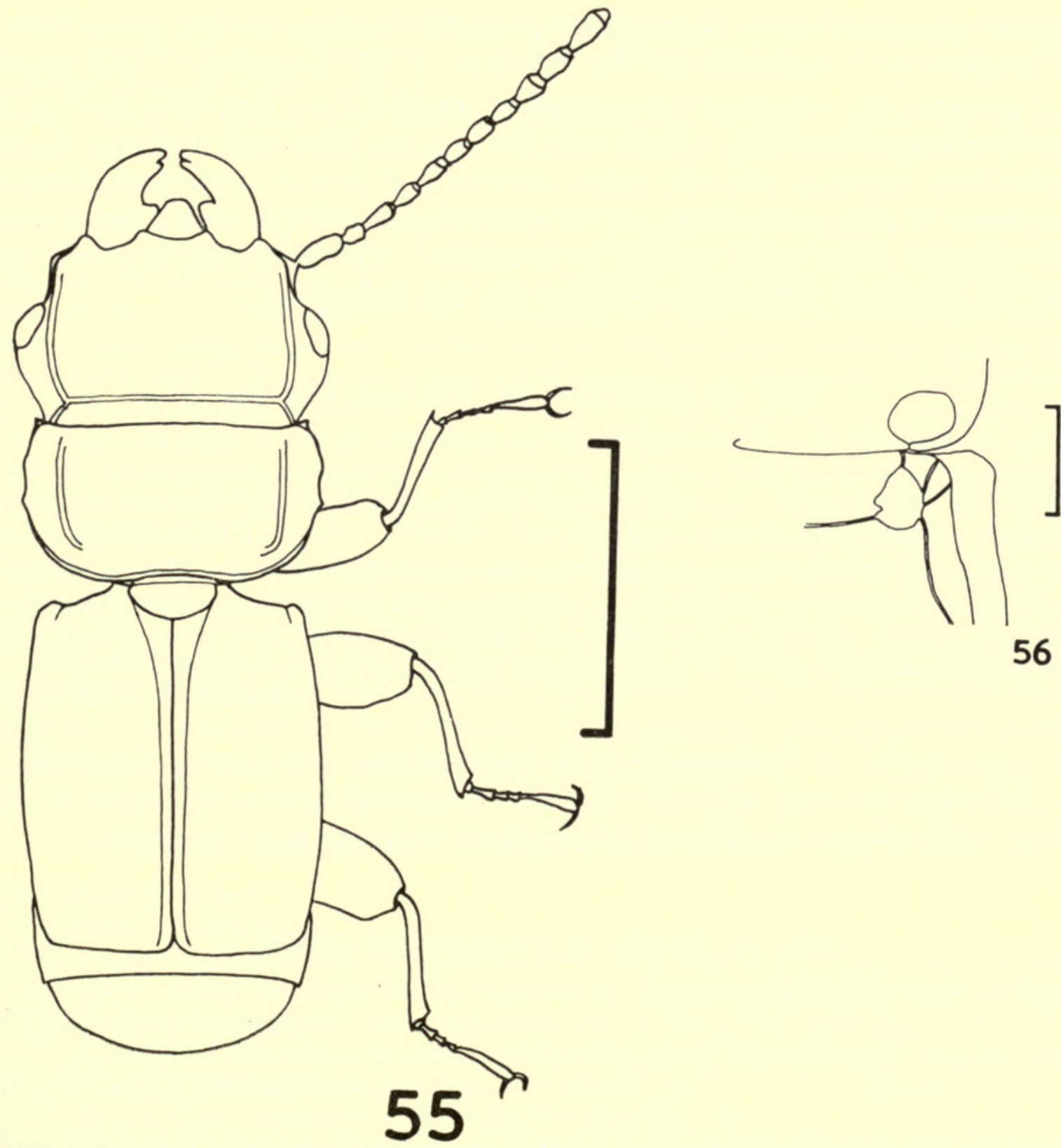

Figs. 55-56. Cucujinus (55) dorsal view ; (56) front and middle coxal cavities. Scale lines: Fig. $55=2 \mathrm{~mm}$. ; Fig. $56=0.25 \mathrm{~mm}$. 
Scutellum semicircular; elytra leaving at least last abdominal segment and often one or two more exposed dorsally; each elytron subtruncate, each separately rounded to apico-sutural angle ; elytra not carinate laterally and with only a sutural line distinct, other regions of cells obsolescent or obsolete.

Genae normal ; gular sutures distinct ; anterior coxae spherical, their cavities closed posteriorly, closure dorsal in relation to rest of cavity ; coxae very widely separated ; intercoxal process of prosternum slightly concave posteriorly; mesocoxal cavities of rather irregular shape, not circular; mesepimeron and metepimeron contributing to mesocoxal cavity; hind margin of mesosternum convex posteriorly; suture between metasternum and metepisternum curving outwards posteriorly, not straight ; median line of metasternum not reaching anterior margin ; metasternum about as long as first three abdominal sternites combined; intercoxal process of first abdominal sternite very slightly convex anteriorly, this sternite twice as long as second, second to fourth subequal, fifth about as long as the first; trochantero-femoral junctions of normal type ; legs subequal ; femora flattened and dilated in one plane ; tarsal formula 5-5-5 in female, either $5^{-5-4}$ or rarely $5^{-5-5}$ in male.

A species described from Madagascar probably belongs to this genus but differs from Cucujinus s. s. especially in the structure of the prothorax. This species, for which I propose the subgenus Paracucujinus subgen. n., was described as Laemophloeus brevipennis Grouvelle. Since only the type has been seen and since L. coquereli Grouvelle from Réunion and one other undescribed species from that island are all the specimens I have seen belonging to this subgenus, a full study must wait until further material from these islands is available. The following key will serve to indicate the principal differences between the two subgenera.

\section{Key to Subgenera of Cucujinus Arrow}

I. Front of head with the outer emargination on each side shallower than the adjacent ; labrum almost triangular in shape ; antennae with terminal segments much thicker than the intermediate; pronotum with rounded anterior and obsolete posterior angles; scutellum rounded posteriorly . . . . C CUCUJINUS Arrow,

- Front of head with the outer emargination on each side deeper than the adjacent; labrum almost semicircular in shape ; antennae with the terminal segments hardly, if at all, thicker than the intermediate, pronotum with acute, somewhat denticulate anterior angles and sharp, obtuse posterior angles; scutellum angled posteriorly

PARACUCUJINUS subgen. n.

The type species of Paracucujinus is Laemophloeus brevipennis Grouvelle, I9o6. The following key will separate the two described species belonging to the new subgenus, each species of which is known only from the type specimen.

\section{Key to SPEcies of Paracucujinus subgen. $\mathbf{n}$}

I. Eyes situated twice their diameter in advance of the posterior angles of the head coquereli (Grouvelle) comb. n.

- Eyes situated their diameter in advance of the posterior angles of the head

brevipennis (Grouvelle), comb. $n$.

Of previously described species hitherto incorrectly placed, Laemophloeus curtipennis Grouvelle and L. nebulosus Grouvelle properly belong to Cucujinus s.s. and are now placed in that genus comb. $\mathbf{n}$. 
XVI. CRYPTOLESTES Ganglbauer

Leptus Thomson, I863, nec Latreille, I796, nec Duftschmid, I825.

Cryptolestes Ganglbauer, I899.

Fractophloeus Kessel, I92I.

Type species: Cucujus ferrugineus Stephens (selected by Casey, I9r6).

This comparatively large genus includes some species of economic importance and of wide distribution in the world.

I.5-2.5 mm.; body moderately flattened.

Head about as broad as long ; eyes of moderate size and situated in advance of base ; epistome slightly convex, straight or slightly concave anteriorly ; antennae when about half body length, distinctly clubbed, when about as long as body (males of some species) not distinctly clubbed; lateral line represented by a ridge.

Pronotum very slightly to distinctly transverse, rarely exceeding $\mathrm{I} \cdot 5$ times, usually somewhat narrowed basally ; anterior angles distinct and usually obtuse ; posterior angles obtuse to acute, usually obtuse, sometimes obsolescent ; lateral line represented by a raised ridge and a closely approximated internal shallow groove.

Scutellum flatly triangular, approximating to pentagonal in shape ; elytra with the three cells developed, secondary intervals being quite narrow ; rows of punctures additional to striae may be present in cells.

Genae normal; gular sutures obsolescent; anterior coxal cavities closed behind; anterior coxae spherical ; intercoxal process of prosternum straight or very slightly concave posteriorly ; metepimeron just not contributing to mesocoxal cavity ; hind margin of mesosternum straight; metasternum almost as long as first two abdominal sternites combined, median line obsolete anteriorly ; first visible abdominal sternite twice as long as second, second to fourth subequal, fifth somewhat longer ; trochantero-femoral junctions of normal type (front and middle femora grooved ventrally for the reception of the tibiae); tarsal formula $5-5-5$ in female, $5^{-5-4}$ in male.

A discussion of the problems in correctly identifying some species of this genus is given by Lefkovitch (I959b). Briefly, the adults show heterogony to such a subtle but confusing degree that detailed external description is almost valueless. The crucial points required for the identification of the species when using external characters alone are given in the key. As will be seen, no attempt is made to separate those species referred to as the "pusilloides " group, since it was found that constant external characters did not exist. Consequently, identifications of this group of species must be made by examination of the genitalia.

\section{Key to African Species Based on External Characters}

I. Body black in colour

- Body brown in colour

2. Scape of male equal in length to segments two to four combined and toothed dorsally apically

8. planulatus (Grouvelle) (p. 236)

- Scape of male much shorter than segments two to four combined and without any dorsal teeth

3. Hind angles of the pronotum obsolescent (Text-fig. 57) .

I. spartii (Curtis) (p. 232)

- Hind angles of the pronotum well developed (Text-fig. $5^{8}$ ) .

4. Body more than $2 \cdot \mathrm{I} \mathrm{mm}$. in length, well covered with setae; males with antennae hardly longer than those of the female, reaching the basal third of the elytra

6. lepesmei (Villiers) (p. 236) 
- Body $2 \mathrm{~mm}$. or less in length, with or without setae; males with antennae much longer than those of the female, nearly as long as body

5. Body shining, only sparsely covered with setae .

- Body rather dull, thickly covered with setae

Io. atulus sp. n. (p. 238)

6. Antennae of males considerably longer than those of the females, often reaching to the apices of the elytra or beyond

“pusilloides" group (pp. 236-240) 7. pusilloides (Steel \& Howe), 9. turcicus (Grouv.), I2. pusillus (Schön.), I3. ugandae Steel \& Howe, I4. evansi sp. n., I5. minimus $\mathrm{sp}$. n.

- Antennae of males hardly longer than those of the females, reaching to about the basal third of the elytra

7. Mandibles of male without tooth on their external margin; elytra nearly twice as long as head and prothorax combined

- Mandibles of male with a tooth on their external margin; elytra about $1 \cdot 5$ times as long as head and prothorax combined

8. Antennal segments hardly longer than broad, last three segments cylindrical

3. brunneus sp. n. (p. 234)

- Antennal segments at least twice as long as broad, last three segments flattened

9. Hind angles of pronotum obsolescent

2. biskrensis (Grouvelle) (p. 233)

- Hind angles of pronotum distinct

5. capensis (Waltl) (p. 235)

4. ferrugineus (Stephens) (p. 234)

\section{Cryptolestes spartii (Curtis)}

(Text-figs. 59, 60)

Cucujus ater Olivier, I795, nec Fourcroy, I785.

Cucujus piceus Stephens, I83I, nec Olivier, I795.

Cucujus spartii Curtis, 1834 .

Laemophloeus rufipes Lucas, 1849.

Laemophloeus suffusus Wollaston, I87I, syn. n.

So far as at present known, this species is confined to Mediterranean Africa, Madeira and Europe ; it is included in this study since it seems likely to be recorded in the future.

I.8-2.5 mm.; antennae, mouthparts and legs brownish red in colour, remainder of body black; setae yellowish in colour ; in very immature specimens adults entirely brownish red in colour and completely indistinguishable morphologically from C. capensis (Waltl).

Head in males often as broad as or broader than prothorax, truncated triangular in shape, narrower in some males and in all females; eyes situated in advance of base ; median line present basally as an impression; epistome very slightly concave anteriorly; antennae reaching to just beyond base of elytra in both sexes; mandibles of males with a tooth on outer margin ; surface evenly punctured, punctures about as large as an eye facet, separated by about one to three diameters, each with a short seta about two diameters in length ; surface between punctures smooth and shining at vertex, polygonally reticulate elsewhere.

Pronotum very slightly transverse, strongly narrowed basally, narrower than head in some males but usually broader; anterior angles slightly acute in broad-headed males, otherwise obtuse ; hind angles obsolescent or very obtuse, often indistinguishable from slightly denticulate lateral margin of prothorax; surface as on head.

Elytra about $2 \cdot 25$ times as long as their combined width ; the three cells developed, secondary intervals less than half as broad as cells; , each cell with one row of punctures additional to striae ; surface with longitudinal reticulation.

North Africa, Madeira.

For a discussion of the synonymy of this species, see Lefkovitch (I959b). It is now possible to add Laemophloeus rufipes Lucas to this synonymy. There are two 
syntypes in the Lucas collection. An examination of these has enabled me to confirm Grouvelle's placing of this species (Grouvelle, I874). In the last drawer of the Wollaston Madeira collection in the British Museum (Natural History), there is a single specimen agreeing with Wollaston's description of L. suffusus, which was based on a single individual collected by Bewicke. The data of this specimen, which I accept as the holotype of $L$. suffusus, are as follows: on the lower side of the card on which the specimen is mounted "Bewicke", an independent label "Laemophloeus suffusus, Woll." in Wollaston's handwriting. It is quite clearly the same species as C. spartii (Curtis).

\section{Cryptolestes biskrensis (Grouvelle) comb. $\mathbf{n}$.}

(Text-figs. 6I, 62)

Laemophloeus biskrensis Grouvelle, I899.

This large Cryptolestes (2-3 mm.) resembles $C$. pusilloides in its thoracic shape and in the length of the elytra but differs in several other important features. The head is rather foreshortened anterior to the antennal insertions and the truncate epistome is shorter in proportion than in pusilloides. There is a strong sexual dimorphism in the antennae, mainly connected with the fourth to the seventh and ninth to eleventh segments of the antennae which in males increase in length with hardly if any increase in width and the distal segment is about four times as long as broad ; the last three segments in the female are distinctly broader than those preceding. In their total length the antennae of the male reach to about the basal third of the elytra; those of the female are a little shorter.

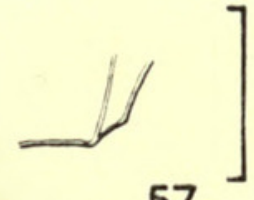

57
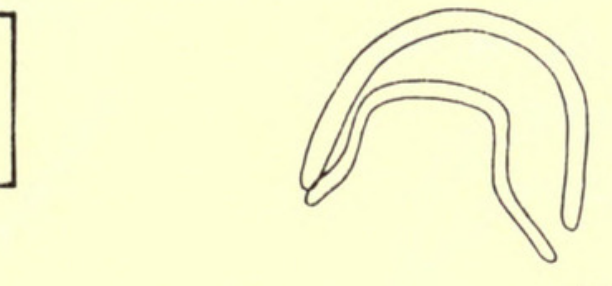

59

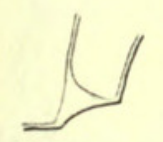

58
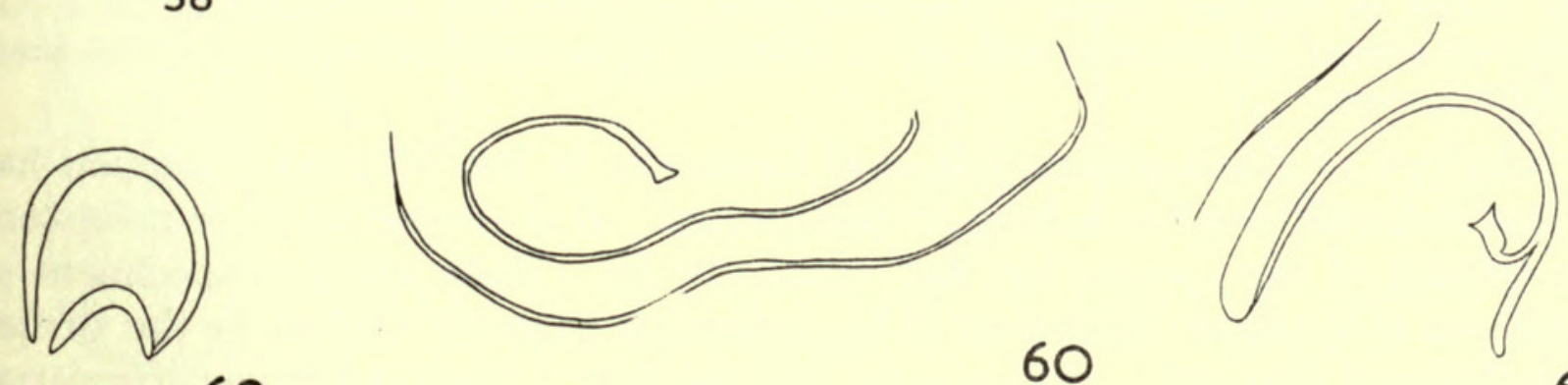

63

Figs. 57-63. Cryptolestes. (57) Hind angle of pronotum of C. spartii and C. capensis ; $(58)$ of $C$. lepesmei and $C$. ferrugineus ; (59) sclerites associated with male genitalia of C. spartii and $C$. capensis; (6I) of $C$. biskrensis (63) of $C$. brunneus; (6o) sclerotization on wall of bursa copulatrix of $C$. spartii and $C$. capensis ; $(62)$ of $C$. biskrensis.

Scale lines : Figs. $57,5^{8}=0.25 \mathrm{~mm}$. ; Figs. $59-63=0.1 \mathrm{~mm}$. 
This species occurs north of the Sahara and in Central Africa. It was not possible to discover any difference in the specimens from the two localities in spite of the improbability of their being conspecific.

North Africa, Uganda, Congo.

I have examined the following specimens : northern form : I "Algerie Chellala "; I "Environs de Biskra De Vauloger "; 3 "Moyen Chari/Fort Archambault/ Bongoul (Ba-Kare)/Mission Chari-Tchad/Dr. J. Decorse I904 Mai ent April" I "Biskra Vauloger"; I "Franchetti/Algerie" (Muséum National d'Histoire Naturelle, Paris); southern form: I "Uganda Katona/Mujenje ix-I9r3"; 9 “Miss. H. de Saeger 63, 578 I803, II57, 2I72, 30I2, 35I9, 3567, 4057” (see Appendix) (Mus. R. Congo Belge).

\section{Cryptolestes brunneus sp. $\mathrm{n}$.}

(Text-fig. 63)

I $\cdot 8-2 \cdot 5 \mathrm{~mm}$. Resembling C. biskrensis but distinguished easily by its darker colour, being a blackish brown, and its almost quadrate prothorax, and the antennal segments which are hardly longer than broad.

Congo.

Holotype and I paratype (males) "Miss. H. de Saeger, 334I" (see Appendix) (Mus. R. Congo Belge).

\section{Cryptolestes ferrugineus (Stephens)}

(Text-figs. 64, 65, 66).

Cucujus testaceus Paykull, I799, nec Fabricius, I787.

Cucujus ferrugineus Stephens, I831.

Cucujus monilicornis Stephens, I831.

Laemophloeus concolor Smith, $185 \mathrm{I}$.

Laemophloeus obsoletus Smith, I85I.

Laemophloeus carinulatus Wollaston, I877, syn. $\mathbf{n}$.

Laemophloeus emgei Reitter, I887.

Laemophloeus alluaudi Grouvelle, I906, syn. n.

This species resembles $C$. spartii (Curtis) very closely, differing externally in that the body is brown in colour, in the hind angles of the pronotum being strongly developed, in the elytra possessing two rows of punctures in each cell in addition to the striae and in the epistome being very slightly convex.

The holotype of Laemophloeus alluaudi Grouvelle in the Alluaud collection has been examined and found to belong to this species. It is somewhat more pubescent than is typical of the species but not unusually so. There are five specimens of Laemophloeus carinulatus Wollaston in his collection from St. Helena in the British Museum (Natural History). One, a male, has the data " Laemophloeus carinulatus, type Woll." and a British Museum týpe label ; the others, which are females, have no data. Wollaston noted that he originally had seven specimens of the species ; I have been unable to locate the remaining pair. The five, which I consider to be syntypes, are the same species and I now select the male to be lectotype. I have no hesitation in synonymising this species with $C$. ferrugineus, of which Wollaston's 
specimens are normal examples; Wollaston, commenting on his species, wrote that it was probably introduced into St. Helena.

C. ferrugineus is Cosmopolitan on stored foods and has also been found under bark, in soil and in most habitats where moderately dry plant material occurs. It can live entirely upon plant material but is facultatively predatory and cannibalistic.

\section{Cryptolestes capensis (Waltl)}

(Text-figs. 59, 60)

Cucujus capensis Waltl, 1834 .

Laemophloeus elongatulus Lucas, 1849 , syn. $\mathbf{n}$.

Laemophloeus vermiculatus Wollaston, 1854 , syn. $\mathbf{n}$.

Laemophloeus clavicollis Wollaston, 1854 , syn. $\mathbf{n}$.

This species differs from C. spartii (Curtis) morphologically in one point only; it is brown in colour in the mature adult and not black (see Lefkovitch, I959a for a biological study of the relationship between these two species).

Europe, South Africa (associated with stored food).

Previously (Lefkovitch, I959b), I stated that the specimens called Laemophloeus elongatulus Lucas that I had seen in European collections of Coleoptera were equally divided between large $C$. ferrugineus and $C$. capensis. Since then $I$ have examined the fifteen syntypes. I select the specimen with a blue label and the words "Laemophloeus elongatulus Lucas" as lectotype. The species is morphologically identical with $C$. capensis.
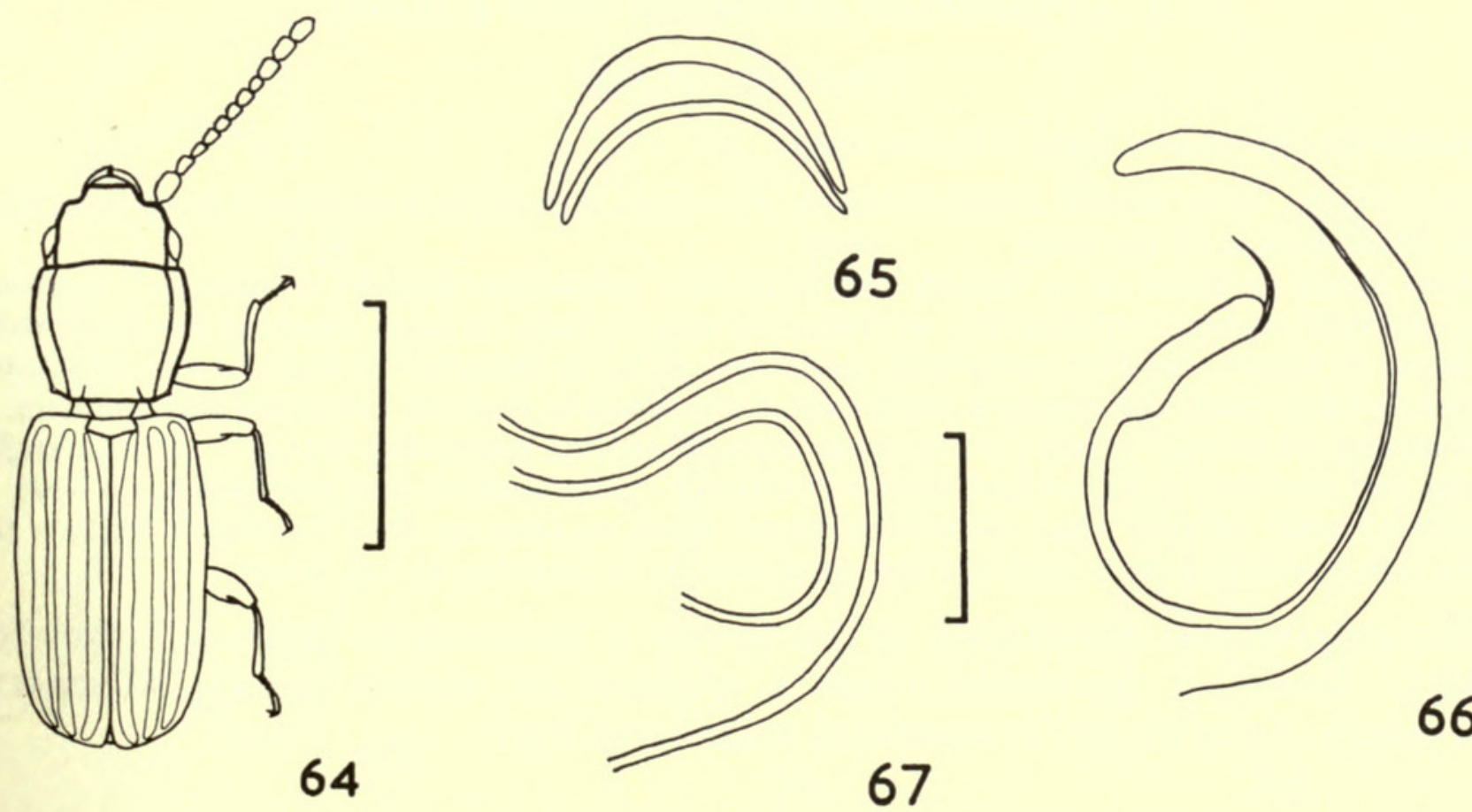

FIgs. 64-67. Cryptolestes. (64) Dorsal view of C. ferrugineus; (65) sclerites associated with male genitalia of C. ferrugineus; (66) sclerotization on wall of bursa copulatrix of $C$. ferrugineus; $(67)$ of C. lepesmei.

Scale lines: Fig. $64=\mathrm{I} \mathrm{mm.} \mathrm{;} \mathrm{Figs.} 65^{-67}=0 \cdot \mathrm{I} \mathrm{mm}$. 
I have also examined the syntypes of Laemophloeus clavicollis Wollaston and L. vermiculatus Wollaston in the British Museum (Natural History) collection and found them to be identical with $C$. capensis.

\section{Cryptolestes lepesmei (Villiers) comb. $n$.}

$$
\text { (Text-fig. 67) }
$$

Laemophloeus lepesmei Villiers, I940.

This species resembles $C$. spartii very closely but differs externally in that the hind angles of the pronotum are as well developed as in $C$. ferrugineus. In size $C$. lepesmei is larger than $C$. spartii, varying between $2 \cdot 1-2 \cdot 7 \mathrm{~mm}$.

In his original description, Villiers wrote that there was a type and six cotypes. On examining the specimens, I found that no type had been labelled as such nor was any indication given in the description of any particular specimen as type. In discussion, Mons. Villiers informed me that he had no particular specimen in mind to be holotype. I select a male as lectotype, but not that specimen illustrated by Villiers since it is distorted on the left side. None of the specimens bear data.

\section{Cameroons, Ethiopia.}

In addition to the 7 syntypes, I have recognized 3 specimens of this species in the British Museum (Natural History) collection. They bear the following data : " Under bark of decaying Mimosa. Abyssinia : Djem-Djem forest. Nearly 9,00o ft. I-X-I926. Dr. H. Scott".

\section{Cryptolestes pusilloides (Steel \& Howe)}

(Text-figs. 68, 69)

Laemophloeus pusilloides Steel \& Howe, 1952.

$\mathrm{I} \cdot 8-2 \cdot 2 \mathrm{~mm}$.; body reddish brown in colour, the elytra in immature specimens being somewhat paler than the rest of the body.

Head about as broad as or slightly narrower than pronotum, slightly transverse; epistome very shallowly concave anteriorly; antennae as long as body in male, reaching the basal third of elytra in female; surface punctured, punctures equal in diameter to facet of eye, separated by one to three times this distance, each with a seta equal to three to five times this diameter.

Pronotum transverse, about $\mathrm{I} \cdot \mathrm{I}-\mathrm{I} \cdot 2$ times as broad as long, narrowing basally ; anterior angles obtuse and rounded, posterior rectangular and sharp; puncturation and vestiture as on head.

Elytra hardly broader than pronotum, about twice as long as their combined width; the three cells developed, each with one row of punctures in addition to two striae.

The geographical distribution of this species is discussed by Howe \& Lefkovitch (I957). Briefly, C. pusilloides occurs in southern and eastern Africa, Australia and South America and is associated with stored food.

\section{Cryptolestes planulatus (Grouvelle) comb. $\mathrm{n}$.}

\section{Laemophloeus planulatus Grouvelle, 1896.}

This species resembles $C$. pusilloides in its general shape but differs as follows: pronotum somewhat more narrowed basally; anterior and posterior angles acute; scape in male equal in 
length to segments two, three and four combined, thickened distally, and dorsally produced into a tooth above the thickening. The scapes of Laemophloeinae are discussed by Lefkovitch $\left(195^{8 b)}\right.$.

\section{Congo.}

Holotype female "I. Bourbon Fairm./type/L. planulatus Grouv ty".

Two colour forms exist, a brown (the typical form) and a black. The following specimens in addition to the holotype have been seen : black form: "Yangambi I95I C. Donis z.II77/Com. Et. Bois Congo R.2394” ; “Yangambi I95I C. Donis z.306/Com. Et. Bois Congo R. 2326" ; brown form : 28 “ Miss. H. de Saeger, 928, I2I4, 2007, 3I86, 3384, 35I9, 3649, 3738, 3744, 4007” (see Appendix) (Mus. R. Congo Belge).

\section{Cryptolestes turcicus (Grouvelle)}

(Text-figs. 70, 7I)

Laemophloeus turcicus Grouvelle, 1876.

This species differs externally from $C$. pusilloides principally in the shape of the pronotum, which in $C$. turcicus is almost quadrate and has projecting acute posterior angles. The pronotum may be narrowed slightly basally in large specimens somewhat as in $C$. pusilloides but the epistome is slightly convex and never concave anteriorly.

Temperate regions of the world except Australia and New Zealand; associated with stored food.

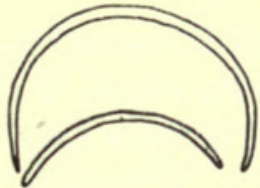

68

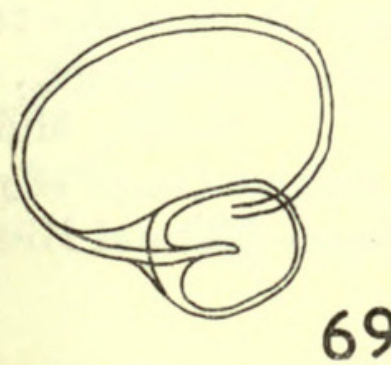

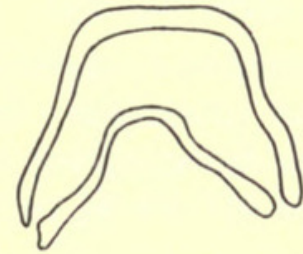

70

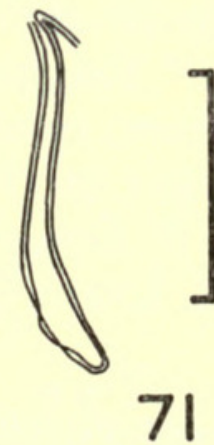

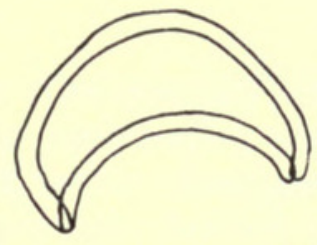

72

FIgs. 68-73. Cryptolestes. (68) Sclerites associated with male genitalia of $C$. pusilloides; (70) of C. turcicus; (72) of C. atulus ; (69) sclerotization on wall of bursa copulatrix of C. pusilloides; (7I) of C. turcicus ; (73) of C. atulus.

Scale line $=0.1 \mathrm{~mm}$. 
C. turcicus is not known to breed in Central Africa but has been recorded from the Belgian Congo and Uganda (Howe \& Lefkovitch, I957). Additional records: 3 " C.T. 4.86/C.B. Esp. Peringuey/in a packet of Cocoa " in the Grouvelle collection, Paris ; 3 specimens " Flour mill. Cape Town M. Howroyd I959” (author's collection).

\section{Io. Cryptolestes atulus sp. n.}

\section{(Text-figs. 72, 73)}

$\mathrm{I} \cdot 8-2 \cdot 2 \mathrm{~mm}$. This species resembles $C$. turcicus but is black and much more shining than that species ; the legs, antennae, mouthparts and the impunctate area at the base of each antenna are reddish in colour. There are only a few short setae on the head and pronotum.

\section{S. Thomé, Congo.}

HoLotype male "Tshuapa: Bokuma ii/iii-I954 R. P. Lootens"; paratypes as follows : I "Ubaugi : Gemena-xi-I935 P. Henrard" ; I "Barumbi -vii-I925. fruit ficus pressée. Lt. J. Ghesquière” ; I "Haut-Uele: Mauda -iii-I925. Dr. H. Schouteden" ; I "Luebo -viii-I92I. coton. Lt. Ghesquière" ; I "Luebo 25-viiiI92I. Dr. H. Schouteden " ; 2 "Eala -iii-I935 J. Ghesquière" ; I "I.R.S.A.C. Tshuapa; Terr. Bikoro, 350 m. Lac Tumba N. Leleup -X-I955”; I "Ruanda: Kisenyi I500 m. 2I-viii-I953 A. E. Bertrand "; I "N’Gazi I4-vii-I952" ; I "Yangambi 5-viii-I952" (Mus. R. Congo Belge); 3 "S. Thomé" (Muséum National d'Histoire Naturelle, Paris).

\section{Cryptolestes atuloides sp. n.}

\section{(Text-figs. 74, 75)}

$\mathrm{I} \cdot 8-2 \cdot 3 \mathrm{~mm}$. This species is very closely related to $C$. atulus $\mathrm{sp}$. $\mathrm{n}$. but differs in that it has longer, more abundant pubescence on the head and pronotum. In shape, the pronotum is closer to that of $C$. ferrugineus rather than $C$. turcicus, being rather more narrowed basally and without such strongly formed hind angles. The setae are about twice as long as the intervals between the punctures.

Congo.

HoLotype male "Luebo -viii-I92I Lt. Ghesquière. Bois mort"; allotype and 3 other paratypes with the same data as the holotype. Other paratypes : 6 " Eala -vii-I935 J. Ghesquière " ; 2 " Luebo I8-viii-I92I Dr. H. Schouteden " ; 3 " Haut Uele: Moto I920 L. Burgeon" ; I "Yangambi 23-vi-I952 Dr. Schedl s.2r3a” ; I "Yangambi 3-vii-I952 s.296"; brown specimens externally resembling C. evansi sp. n. ; “ Kamalembi (Luebo) 2I-ix-I92I. Dr. H. Schouteden ”; " Kasal : Mukumbi I8-X-92I. Dr. H. Schouteden " (Mus. R. Congo Belge) ; I " Belgian Congo I8 m(iles) S.W. of Elizabethville I927. Dr. H. S. Evans” (British Museum (Natural History)).

\section{I2. Cryptolestes pusillus (Schönherr)}

(Text-figs. 76, 77)

Cucujus minutus Olivier, I79I, nec Fourcroy, 1785.

Cucujus pusillus Schönherr, I8I7.

Cucujus testaceus Stephens, I83I. 
Cucujus crassicornis Waltl, I839.

Laemophloeus longicornis Mannerheim, I843.

Loemophloeus (sic) brevis Fairmaire, 1850.

Laemophloeus parallehus Smith, I85I.

Laemophloeus pauper Sharp, 1899.

This species resembles $C$. pusilloides in many ways and since they both occur in stored products, they have often been confused with each other. C. pusillus is much more pubescent, the pronotum more transverse (often as much as $\mathrm{I} \cdot 4$ times), the elytra are comparatively shorter in relation to the rest of the body, and possess two rows of punctures in the cells in addition to the striae. Small specimens of the two species and of $C$. turcicus and $C$. ugandae are virtually indistinguishable from each other externally.

I have seen specimens of this species from almost all parts of AFRICA; associated with stored food.

\section{I3. Cryptolestes ugandae Steel \& Howe}

(Text-figs. 78,79 )

Cryptolestes ugandae Steel \& Howe, 1955 .

Externally, this species is somewhat intermediate between $C$. pusillus and $C$. pusilloides. It has been impossible to find external characters which are really reliable. The epistome is slightly more emarginate than in those species, the anterior margin of the pronotum is just sinuate before the anterior angles and the puncturation on the head and pronotum is finer than is usual in those two species. But all these species vary so much externally that no real reliance can be placed upon these characters.

The distribution of this species is given by Lefkovitch (I957b) and by Howe \& Lefkovitch (I957). It appears to be confined to Central AFrica, associated with stored food.

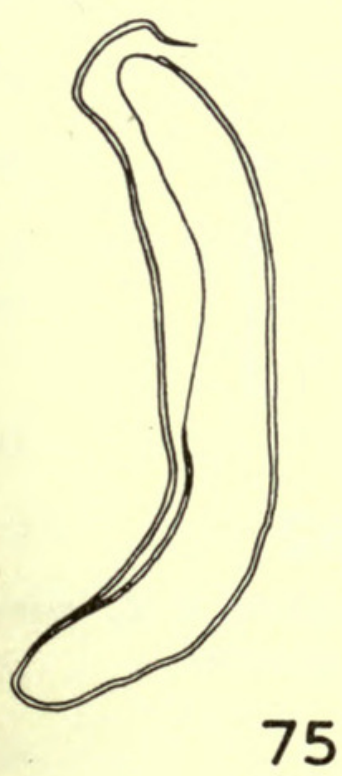

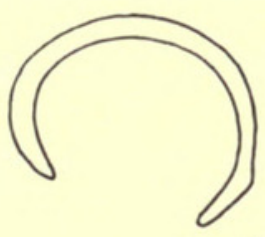
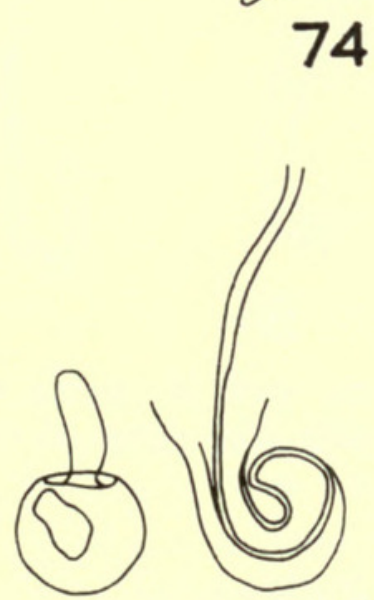
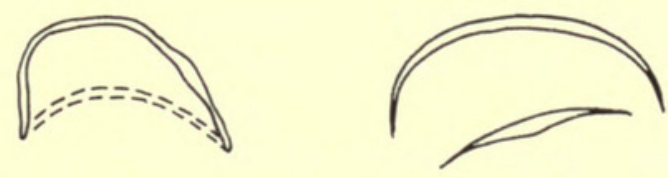

76

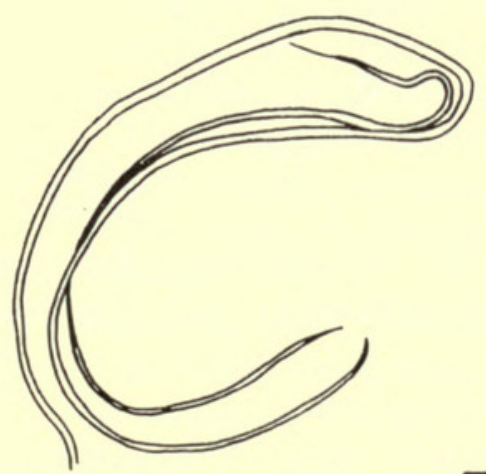

79

Figs. 74-79. Cryptolestes (74) Sclerites associated with male genitalia of $C$. atuloides ; (76) of C. pusillus; (78) of C. ugandae; (75) sclerotization on wall of bursa copulatrix of C. atuloides; (77) of C. pusillus (spermatheca also illustrated); (79) of C. ugandae. 


\section{I4. Cryptolestes evansi sp. n.}

(Text-fig. 80)

$\mathrm{I} \cdot 8-2 \cdot 2 \mathrm{~mm}$. This species differs from $C$. pusilloides in that the pronotum is less transverse being scarcely broader than long and of shape similar to that of a small female $C$. turcicus. In the length of the body and in its other proportions the species is identical with C. pusilloides.

Congo.

Holotype male " Belgian Congo I8 m(iles) S.W. of Elizabethville I928 Dr. H. S. Evans "; 2 paratypes with the same data except as follows : male dated I3.xi.r927 and female dated I3.ii.I928 (British Museum (Natural History)).

\section{I5. Cryptolestes minimus sp. n.}

(Text-figs. 8I, 82)

I $\cdot 8-2 \cdot 3 \mathrm{~mm}$. Resembling $C$. pusilloides very closely but differing in the more sharply defined posterior angles to the prothorax, in the relative broadness of the elytra in comparison with the prothorax (it is difficult to give a value to this difference) and in the yellowish rather than reddish brown colour of the body.

Angola.

Holotype male "Angola 42II.9 Alto Chicapa, sous écorce arbre tombe 27-vir954. Ed. Luna de Carvalho" ; 4 paratypes ( 2 males and 2 females) with the same data as the holotype; 3 paratypes "Angola I824.4.3 Serra do Moco, Luimbale (Huambo), sous écorce arbre tombe, Io-ix-I949. A. de Barros Machado"; I "Angola 4I94.5 Alto chicapa, gal. forest. riv. Ngungo, dans tronc pourri 27-i-I954. Ed. Luna de Carvalho ” (British Museum (Natural History)).

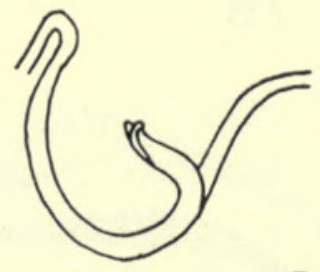

80

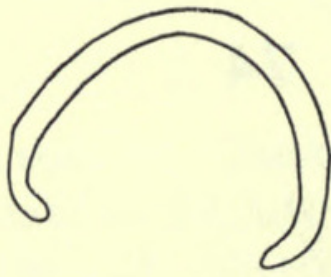

81

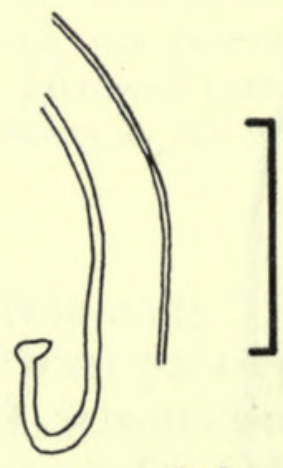

82

FIgs. 8o-82. Cryptolestes (8o) Sclerotization on wall of bursa copulatrix of C. evansi;

(82) of C. minimus ; (8I) sclerites associated with male genitalia of C. minimus. Scale line $=0 \cdot 1 \mathrm{~mm}$.

\section{AC KNOWLEDGEMENTS}

I am grateful to the authorities and staffs of the many museums and institutions who have lent me specimens or given me hospitality for the furtherance of this study. I wish, in particular, to mention the British Museum (Natural History) whose staff have given considerable assistance, almost weekly, during the last four years. 
I am indebted to Miss C. M. F. von Hayek, Dr. E. B. Britton and Mr. R. D. Pope for the time they have given in the discussion of various points that have arisen and especially to Mr. J. A. Balfour-Browne for the care with which he has read the manuscript.

\section{A PPENDIX}

Data relating to specimens collected in the Parc National de la Garamba in the Congo by the Mission H. de Saeger and referred to in the text by a number (see also de Saeger, I956).

Reference

Number

Collector

63
578
928

H. de Saeger

G. Demoulin

H. de Saeger

I 57

I 2 I 4

1724

1803

2007

2062

2115

2172

260I

3012

31 86

3235

3296

334I

3379

$33^{8} 4$

3488

3519

3563

3567

,

H. de Saeger
J. Verschuren

I4 . V. I95 I

$25 \cdot$ V. I95 I

29.vi. I95I

I3. vii. I95 I

I9. vii. I95 I

30.vii. I95 I

I 5 . X. I95 I

I6. i. 1952

I 2 . iii. 1952

I 3. iii. 1952

7.iv. $195^{2}$

I9.iv. $195^{2}$

2o.iv. 1952

28.iv. $195^{2}$

20.v. $195^{2}$

26.v. $195^{2}$

3.vi.1952

3o.v. 1952

\section{Data}

Submerged vegetation.

Savanna with trees.

Alighting on fruits of Ficus capensis.

At edge of river in high grass.

Between burned savanna and river in short grass.

Collected in leaves of Caloncoba welwitschii.

Shaded pool on Canthium cf. hispidum.

Under bark of Cassia siamea imported for building.

Under bark of dead tree, wood moist and partially decayed.

Very moist decomposing wood.

From grass in savanna.

Dead trees and branches on ground in degenerate forest.

Savanna, on left bank of Nambira.

In fallen trees, decay hardly begun.

In dead trunks of Neoboutonia.

Savanna, in dry stems of Nauclea latifolia killed by fire in January.

In stems and bracts in a mass of Oxytenanthera abyssinica.

Under trunk, in spaces between the bark of Anogeissus schimperi.

Savanna with occasional trees; in fallen dead branches.

Savanna with Lophira trees.

Savanna with shrubs; fallen dead branches.

Thin forest ; fallen dead branches.

Savanna; in flowers, mainly Setaria sphacelata, Sporobolus pyramidalis and various Cyperaceae. 
Reference

Number

3649 .

3736

3738

3744

3787

4007

4057
Collector

H. de Saeger

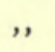

,

,

,

,

,

A P P E N D I X-cont.

Date

I8. vi. 1952

4 . vii. $195^{2}$

4. vii. 1952

7.vii. 1952

I5. vii. I952

I.ix. $195^{2}$

I6. ix. $195^{2}$
Data

Fallen dead tree on stony rubbish.

Temporary pool edges, in decaying vegetation.

Dead tree of Irvingia smithii

Dead branches of Erythrophloeum Chlorophora.

In dead, fallen trees of Voacanga obtusa.

Savanna, in dead branches of woody shrubs.

Marsh, in plant layer (Jussiaea).

\section{REFERENCES}

References to species and genera mentioned in the text but not included in this bibliography are given by Hetschko (1930).

Casey, T. L. I884. Revision of the Cucujidae of America North of Mexico. Trans. Amer. ent. Soc. $11: 66-\mathrm{I} 12$.

I9r6. Some random studies among the Clavicornia. In Memoirs on the Coleoptera $7: 35-300$.

Grouvelle, A. I874. Ann. Soc. ent. Fr. (5) 4 : xxix.

- 1908. Coleoptères clavicornes de l'Afrique Australe et Oriental. Rev. ent. (Caen) 27 : 127192.

Heтschкo, A. I930. Cucujidae in Junk, W., Coleopterorum Catalogus 109: I-I 22.

Howe, R. W. \& Lefkovitch, L. P. I957. The distribution of the storage species of Cryptolestes (Col. Cucujidae). Bull. ent. Res. 48: 795-809.

Kessel, F. I92I. Neue Monotomiden, Cucujiden u. Passandriden aus der Sammlung des Deutschen Entomologischen Museums in Berlin. Arch. Naturgesch. 87 : 25-33.

Lefrovitch, L. P. I957a. Further records of Laemophloeinae (Col. Cucujidae) in stored products. Ent. mon. Mag. $93: 239$.

- I957b. The biology of Cryptolestes ugandae Steel and Howe (Coleoptera, Cucujidae), a pest of stored products in Africa. Proc. zool. Soc. Lond. $128:$ 4I9-429.

- I958a. A new genus and species of Laemophloeinae (Col. Cucujidae) from Africa. Ibid. $93: 27$ I -273 .

I958b. Unusual antennal characters in some Laemophloeinae (Coleoptera: Cucujidae) and their taxonomic importance. Proc. R. ent. Soc. Lond. (B) 27 : 93-roo.

- r959a. Biological evidence for the specific separation of Cryptolestes capensis (Waltl) from C. spartii (Curtis) (Coleoptera : Cucujidae). Proc. R. ent. Soc. Lond. (A) 34: 44-48. I959b. A revision of the European Laemophloeinae (Coleoptera: Cucujidae). Trans. R. ent. Soc. Lond. 111 : 95-118.

1962. The taxonomic position of Laemophloeus raffrayi Grouvelle. Verhand. XI. Int. Kongr. Ent. $1: 78-80$.

Peyerimhof, P. DE. I948. Description d'un Laemophloeus [Col. Cucujidae] algérien commensal de Triotemnus Grangeri Peyerh. [Scolytidae]. Bull. Soc. ent. Fr. 53 : 97-99.

SAEger, H. DE. I956. Entomologie Renseignements Eco-biologiques. Explor. Parc. Nat. Garamba, 5 : I-555.

Steel, W. O. (in preparation) (A revision of the genus Cucujinus Arrow sensu stricto).

Steel, W. O. \& Howe, R. W. I952. A new species of Laemophloeus (Col. : Cucujidae) associated with stored products. Proc. R. ent. Soc. Lond. (B) 21: 86-88.

- 1955. A new species of Cryptolestes (Col.: Cucujidae) associated with stored products. Ibid. 24 : 107-109.

Villiers, A. I940. In Paulian, R. \& Villiers, A., Les coleoptères des Lobelias de montagnes. Rev. franc. Ent. $7: 72-83$. 


\section{INDEX OF LAEMOPHLOEINAE}

(Synonyms in italics ; bold page numbers refer to descriptions, those in italics to a mention in a key)

africanus sp. n., Placonotus, 177 , I8I, 182 alluaudi Grouvelle, Laemophloeus, 234 alternans (Erichson), Leptophloeus, I68, 202,

204, 206, 207

ambiguus (Grouvelle), Gannes, I74, 175 ambiguus Grouvelle, Laemophloeus, I 75 angustulus Leconte, Laemophloeus, 201 anormus Grouvelle, Laemophloeus, 205 anormus (Grouvelle), Leptophloeus, 205 ater Olivier, Cucujus, 232 ater sp. n., Leptophloeus, 203, 204, 205 atuloides sp. n., Cryptolestes, 232, 238, 239 atulus sp. n., Cryptolestes, 232, 237, 238 axillaris Wollaston, Laemophloeus, 206 axillaris (Wollaston), Leptophloeus, 203, 205,

206

bimaculatus sp. n., Xylophloeus, I89, I9I, 193

biskrensis (Grouvelle), Cryptolestes, 232, 233, 234

biskrensis Grouvelle, Laemophloeus, 227, 233, Blubos gen. n., I72, 194

bolivari Grouvelle, Laemophloeus, I 85 bolivari (Grouvelle), Placonotus, I 78, 185 brevipennis (Grouvelle), Cucujinus (Para. cucujinus), 230

brevipennis Grouvelle, Laemophloeus, 230 brevis Fairmaire, Loemophloeus (sic), 239 brightensis Blackburn, Lathropus, I97 brunneus sp. n., Cryptolestes, 232, 233, 234 brunneus Grouvelle, Laemophloeus, 228 brunneus (Grouvelle), Planolestes, 226, 228 buplevi (sic) Peyerimhof, Laemophloeus, 209 bupleuri (Peyerimhof), Leptophloeus, 203, 209

capensis (Waltl), Cryptolestes, I 70, I84, 232, 233, 235

capensis Waltl, Cucujus, 235

capensis Chevr. (sic), Laemophloeus, 224 capitus, sp. n., Leptophloeus, 204, 208, 209 carinulatus Wollaston, Laemophloeus, 234 cassavae sp. n., Leptophloeus, 204, 207 castaneus (Erichson), Notolaemus, I68, 223, 226

chrysomeloides sp. n., Xylophloeus, I9I, 192 clarus Grouvelle, Laemophloeus, 223

clarus (Grouvelle), Notolaemus, 220, 22 I, 223 clavicollis Wollaston, Laemophloeus, I84, 235, 236

clematidis (Erichson), Leptophloeus, I68, 202, 206, 207209

concolor Smith, Laemophloeus, 234

coquereli (Grouvelle), Cucujinus (Paracucujinus, 230

coquereli Grouvelle, Laemophloeus, 230

cornutus Grouvelle, Laemophloeus, 228

cornutus sp. n., Leptophloeus, 202, 203, 2 Io

cornutus (Grouvelle), Planolestes, 226

corticinus (Erichson), Cryptolestes, I68

crassiceps (Sharp), Narthecius, 2 I I

crassiceps Sharp, Paraphloeus, 2 I I

crassicornis Waltl, Cucujus, 239

Cryptolestes Ganglbauer, I68, I70, I73, I84, I $87,196,226,227,231$

Cucujus (s.1.), 220, 23I, 232, 234, 235, 238

Cucujinus Arrow, I68, I69, I72, 228, 230

curtipennis (Grouvelle), Cucujinus, 230

curtipennis Grouvelle, Laemophloeus, 230

decoratus Grouvelle, Laemophloeus, I 86 decoratus (Grouvelle), Placonotus, I77, 186 dentatus sp. n., Xylophloeus, I9I, 194 ditomoides (Grouvelle), Passandrophloeus, $2 \mathrm{I} 5$

divergens Grouvelle, Laemophloeus, 2 I 3 dolce sp. n., Placonotus, $177, \mathbf{1 7 8}$, I 79 donacioides Wollaston, Laemophloeus, I 83 donacioides (Wollaston), Placonotus, I77, 183, I 87

duplicatus (Waltl), Cryptolestes, I68

ealaensis sp. n., Placonotus, I77, I8I, 182 eichelbaumi Grouvelle, Laemophloeus, 2 I9 eichelbaumi (Grouvelle), Mariolaemus, 218, 219

elgonesis sp. n., Xylophloeus, I9I, 193

elli sp. n., Notolaemus, 220, 221, 222

elongatulus Lucas, Laemophloeus, 235

emgei Reitter, Laemophloeus, 234

escalevae Grouvelle, Laemophloeus, 219 escalerai (Grouvelle), Mariolaemus, 2 I 8, 219 evansi sp. n., Cryptolestes, 232, 240 exornatus Grouvelle, Laemophloeus, I86, I87 exornatus (Grouvelle), Placonotus, I77, 186

falcidens (Grouvelle), Passandrophloeus, 2 I 5 
ferrugineus (Stephens), Cryptolestes, I70, 232, $233,235,236,238$

ferrugineus Stephens, Cucujus, 23I, 234 ferrugineus sp. n., Microlaemus, I97, 198 fractipennis (Motschuisky), Cryptolestes, I68 Fractophloeus Kessel, 23I

Gannes gen. n., I69, I72, 174, I 76 gestroi Grouvelle, Laemophloeus (s.1.), I7I glabriculus (Grouvelle, Laemophloeus, 213 glabriculus (Grouvelle), Passandrophloeus, 213

grandiceps Leconte, Narthecius, 2 10 granulatus Wollaston, Laemophloeus, I 83

haroldi Reitter, Narthecius, $2 I I$ hypobori (Perris), Leptophloeus, I68, 207

immoderatus sp. n., Gannes, I74, 175 insularis Grouvelle, Laemophloeus, 202 insularis (Grouvelle), Leptophloeus, 202 interceptus (Grouvelle), Microlaemus, I97

janeti Grouvelle, Laemophloeus, 209 janeti (Grouvelle), Leptophloeus, 203, 204, 205, 209, 2 I0

juniperi (Grouvelle), Leptophloeus, I68

Laemophloeus Dejean (s.s.), I68, $I 7 I$

Laemophloeus (s.1.), I67, I68, I7I, 202

laevicornis Lefkovitch, Planolestes, 226, 228

Lathropus Erichson, I68, I69, I7I

lepesmei (Villiers), Cryptolestes, 23I, 233, 235,236

lepesmei Villiers, Laemophloeus, 236

Leptophloeus Casey, I68, I69, I73, I99, 201, 2 I3

Leptus Thomson, 23I

liganus sp. n., Notolaemus, 220, 225

linearis Grouvelle, Laemophloeus, 207

linearis (Grouvelle), Leptophloeus, 204, 207

livens Grouvelle, Laemophloeus, 218

livens (Grouvelle), Mariolaemus, 218

longicollis Sharp, Paraphloeus, 2 I I

longicornis Mannerheim, Laemophloeus, 239

longicornis sp. n., Mestolaemus, 215, 216

longicornis Macleay, Placonotus, I 76

lucidus Grouvelle, Laemophloeus, 205

lucidus (Grouvelle), Leptophloeus, 203; 205, 207

Magnoleptus gen n., I69, I70, I73, 199

majus, sp. n., Placonotus, $I 77,179$

Mariolaemus gen. n., I74, 216, 217

matris sp. n., Blubos, I94, 196
Mestolaemus gen. n., I73, 215

mestus sp. n., Placonotus, $I 77, \mathbf{1 7 9}$

Microlaemus gen. n., I 7o, I73, 196

micromma Arrow, Cucujinus, 228

mimosae sp. n., Xylophloeus, I9o, 192

minimus sp. n., Cryptolestes, 232, 240

minutus Olivier, Cucujus, 238

mirificus Grouvelle, Laemophloeus (s.1.), I 7 I

mirus Grouvelle, Laemophloeus, I83, 184

misellus Grouvelle, Laemophloeus, 216, 218

misellus (Grouvelle), Mariolaemus, 218, 2 I9

mobilis Grouvelle, Laemophloeus, 202, 208

mobilis (Grouvelle), Leptophloeus, 203, 208

monilicornis Stephens, Cucujus, 234

monilis (Fabricius), Laemophloeus, I68

mossus sp. n., Placonotus, $I 77,187$

mucunae sp. n., Leptophloeus, 203, 206

muticus (Fabricius), Laemophloeus, I68

Narthecius Leconte, I69, I73, 210, $2 I 2$

nebulosus (Grouvelle), Cucujinus, 230

nebulosus Grouvelle, Laemophloeus, 230

nigricollis Lucas, Laemophloeus, I68

nitens Leconte, Laemophloeus, 183

nitens (Leconte), Placonotus, I83

notabilis Grouvelle, Laemophloeus, I68

Notolaemus Lefkovitch, I68, I74, 220

obsoletus Smith, Laemophloeus, 234

opaculus Grouvelle, Laemophloeus, 205

opaculus (Grouvelle), Leptophloeus, 202, 203, 205

palpalis Waterhouse, Laemophloeus, I98, I99 palpalis (Waterhouse), Microlaemus, $I 97,198$, I99

Paracucujinus subgen. n., 230

parallelicollis sp. n., Magnoleptus, 200, 201

parallelus Smith, Laemophloeus, 239

parallelus sp. n., Leptophloeus, 203, 206

Paraphloeus Sharp, 210, 211

Passandrophloeus Kessel, I69, I73, 2 I I, 213

patens Grouvelle, Laemophloeus, I89, I9I

patens (Grouvelle), Xylophloeus, I87, I89, I9o, 191

pauper Sharp, Laemophloeus, 239

peringueyi Grouvelle, Laemophloeus, 224

peringueyi (Grouvelle), Notolaemus, 220, 22 I,

224, 225

perrieri Grouvelle, Laemophloeus, $22 \mathrm{I}$

perrieri (Grouvelle), Notolaemus, 220, 221

perspicuus Grouvelle, Laemophloeus, 222

perspicuus (Grouvelle), Notolaemus, 220, 22I,

222, 223

Phloeipsius Casey, 217 
piceus Stephens, Cucujus, 232

picinus Grouvelle, Laemophloeus, 226

picinus (Grouvelle), Notolaemus, 220, 226

picipennis (Grouvelle), Microlaemus, 197

Placonotus Macleay, I68, I69, I72, I74, 176, 224

Planolestes Lefkovitch, $I 73$, 222, 226

planulatus (Grouvelle), Cryptolestes, 23I, 236

planulatus Grouvelle, Laemophloeus, 236

politissimus Wollaston, Laemophloeus, I83, I 84

politissimus (Wollaston), Placonotus, 177 , I 79, 183, I 85

problematicus sp. n., Leptophloeus, 202, 203, 210

pugnaceus sp. n., Magnoleptus, I99, 200, 201

punctatus sp. n., Leptophloeus, 203, 204, 207, 208, 209

pusilloides (Steel \& Howe), Cryptolestes, 23I, 232, 233, 236, 237, 239, 240

pusilloides Steel \& Howe. Laemophloeus, 236 pusillus (Schönherr), Cryptolestes, 232, 238, 239

pusillus Schönherr, Cucujus, 238

raffrayi Grouvelle, Laemophloeus (s.1.), I72

Rhinolaemus Steel, I69

Rhinomalus Gemminger \& Harold, I69

Rhinophloeus Sharp, I69

riartus sp. n., Notolaemus, 220, 223

rufipes Lucas, Laemophloeus, 232

schedli sp. n., Narthecius, 211, 212

sepicola (Müller), Lathropus, I68

Silvanophloeus Sharp, I76, I83, I86

slades sp. n., Microlaemus, I97, I98, 199

spartii (Curtis), Cryptolestes, 23I, 232, 233 ,

$234,235,236$ spartii Curtis, Cucujus, 232

spinosus Grouvelle, Laemophloeus, 2 I 3

spinosus (Grouvelle), Passandrophloeus, 2 I 5

stenoides Wollaston, Laemophloeus, 206

stenoides (Wollaston), Leptophloeus, 204, 206

subniger Grouvelle, Laemophloeus, 2 I9

subtruncatus sp. n., Placonotus, I77, I79,

181, I 82

suffusus Wollaston, Laemophloeus 232, 233

sulcifrons (Grouvelle), Microlaemus, I97

suturalis Grouvelle, Narthecius, 2 I I, 2 I 2

sylvestris (Grouvelle), Microlaemus, I97

tastus sp. n., Placonotus, $I 77, \mathbf{1 7 8}$, I 79

tenebrosus Grouvelle, Laemophloeus, I98

testaceus Paykull, Cucujus, 234

testaceus Stephens, Cucujus, 238

testaceus (Fabricius), Placonotus, I68, I76

Truncatophloeus Kessel, 201, 202

turcicus (Grouvelle), Cryptolestes, 232, 237, 238,239

turcicus Grouvelle, Laemophloeus, 237

turneri sp. n., Microlaemus, I96, 197, I98

ugandae Steel \& Howe, Cryptolestes, 232, 239 unicolor Grouvelle, Laemophloeus, I87, I88 unicolor (Grouvelle), Xylolestes, 188, I89 unifasciatus Latreille, Cucujus, 220

unifasciatus (Latreille), Notolaemus, 226

unifasciatus sp. n., Xylophloeus, I89, I9I

193

vermiculatus Wollaston, Laemophloeus, 235, 236

Xylolestes gen. n., I72, 187, 190

Xylophloeus gen. n., I72, 189 


\section{$2 \mathrm{BHL}$ Biodiversity Heritage Library}

Lefkovitch, L P. 1962. "Revision of African Laemophloeinae (Coleoptera: Cucujidae)." Bulletin of the British Museum (Natural History) Entomology 12, 165-245. https://doi.org/10.5962/bhl.part.5875.

View This Item Online: https://www.biodiversitylibrary.org/item/19513

DOI: https://doi.org/10.5962/bhl.part.5875

Permalink: https://www.biodiversitylibrary.org/partpdf/5875

\section{Holding Institution}

Natural History Museum Library, London

\section{Sponsored by}

Natural History Museum Library, London

\section{Copyright \& Reuse}

Copyright Status: In copyright. Digitized with the permission of the rights holder.

Rights Holder: The Trustees of the Natural History Museum, London

License: http://creativecommons.org/licenses/by-nc-sa/4.0/

Rights: http://biodiversitylibrary.org/permissions

This document was created from content at the Biodiversity Heritage Library, the world's largest open access digital library for biodiversity literature and archives. Visit BHL at https://www.biodiversitylibrary.org. 